\begin{abstract}
Title of Document:

THE BRANDSTETTER TUNEBOOK: SHAPENOTE DISSEMINATION AND THE GERMANS OF WESTERN MARYLAND

Joshua Rush Barnett, MA, 2012

Directed By:

Professor Patrick Warfield, School of Music

The newly discovered personal tunebook of Maria Brandstetter (1820) reveals that shape-note hymnody was alive in the mountains of Western Maryland in the early nineteenth century. The tunebook's presence in the region fills in a gap left by the usual dissemination story of shape-note hymnody, which emphasizes an exchange between Eastern Pennsylvania and the Shenandoah Valley of Virginia. The tunebook is also connected to the German community that migrated from Pennsylvania into Maryland and Virginia in the early 1800s, and thus sheds light on the musical culture of the German-American immigrants of Western Maryland. Finally, the contents of the Brandstetter tunebook suggest that pivotal Virginia shape-note composer and compiler of the Kentucky Harmony, Ananias Davisson, may have first been exposed to shape-note music by migrating Germans like the Brandstetter family.
\end{abstract}




\title{
THE BRANDSTETTER TUNEBOOK: SHAPE-NOTE DISSEMINATION AND THE GERMANS OF WESTERN MARYLAND
}

\author{
By \\ Joshua Rush Barnett \\ Thesis submitted to the Faculty of the Graduate School of the \\ University of Maryland, College Park, in partial fulfillment \\ of the requirements for the degree of \\ Master of Arts \\ 2012
}

Advisory Committee:

Professor Patrick Warfield, Chair

Professor Barbara Haggh-Huglo

Professor Robert C. Provine 
(C) Copyright by

Joshua Rush Barnett

2012 


\section{Acknowledgements}

My work on this thesis was only possible with the contributions of numerous people—far too many to name everyone. But I must thank, first and foremost, Dr. Patrick Warfield, my advisor for more than just thesis-related issues. His guidance has been invaluable, and the approach he takes to his field and profession as a scholar and teacher is a model I can only strive to imitate.

I owe a special thanks to Vincent Novara and the University of Maryland's Special Collections in Performing Arts division. Vin first brought the Brandstetter tunebook to my attention, and he and the rest of the SCPA staff have aided me without hesitation through every step of my research.

I must also acknowledge the lessons and support I received from all of my professors, in undergraduate study at St. Mary's College of Maryland as well as during my master's work at the University of Maryland. Together, these scholars and educators have shaped my academic life and given me the opportunity to produce this study.

I would also like to thank my friends. To my peers at the University of Maryland: the small acts of kindness and support have been so helpful and meant far more than I could express. To my friends outside the University: thanks for offering occasional and much needed diversions, I genuinely treasure the balance you all have provided for me. To the shape-note community: I truly appreciate your acceptance, wisdom, and spirit; this music has changed my life.

Finally, and forever, I am grateful to my family. Their love and support has been a constant in my life; I am so thankful for this unshakeable foundation. 
"Within Thy circling pow'r I stand, On ev'ry side I find Thy hand."

- $\quad$ The Sacred Harp, AKIN, 472

"My friends, come listen awhile, And I will tell you a story."

- The Sacred Harp, ANTHEM ON THE SAVIOR, 355 


\section{Table of Contents}

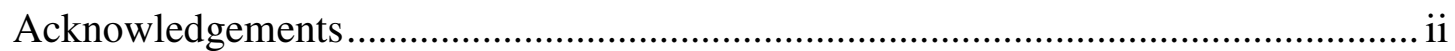

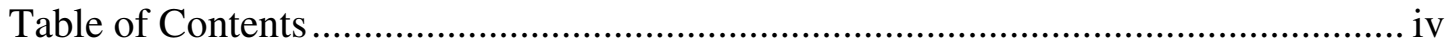

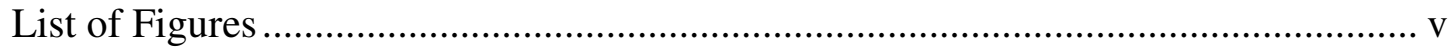

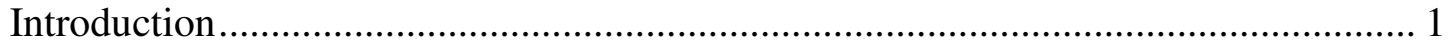

Literature Review............................................................................................ 3

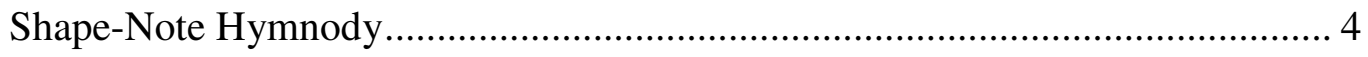

German-American Sacred Music.............................................................. 10

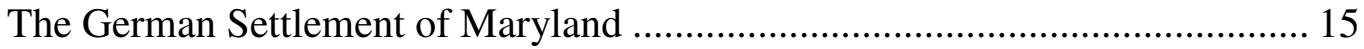

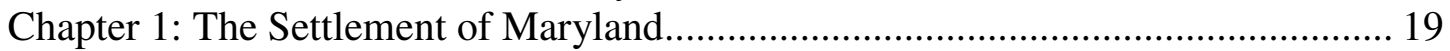

Calvert's Colony along the Chesapeake ................................................................ 19

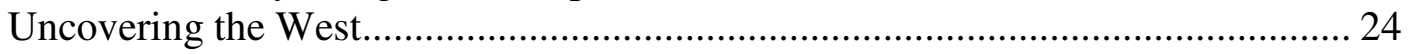

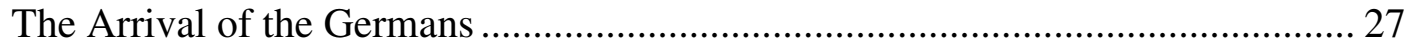

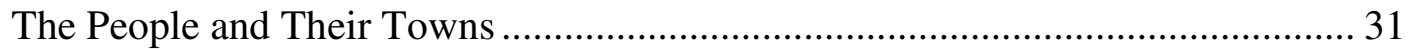

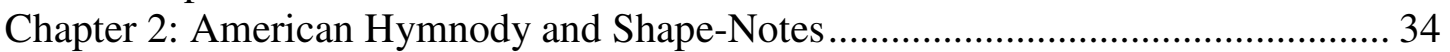

Early American Psalmody .................................................................................... 35

Singing by the Note: Singing Schools and Tunebooks....................................... 38

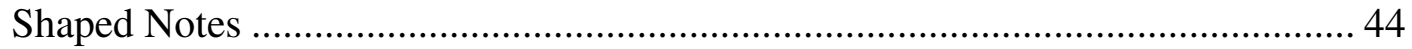

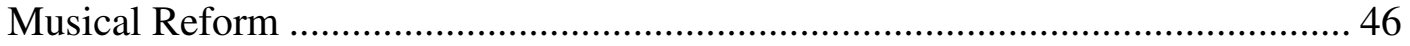

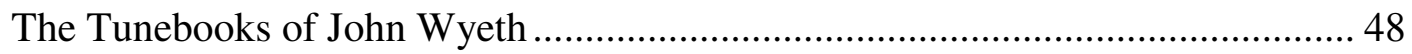

Into the Mid-Atlantic and the South: The Work of Ananias Davisson................... 51

Chapter 3: German-Immigrant Musical Culture ........................................................... 57

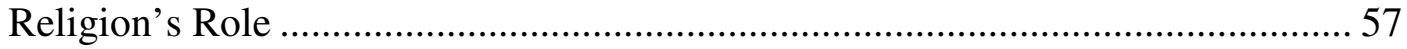

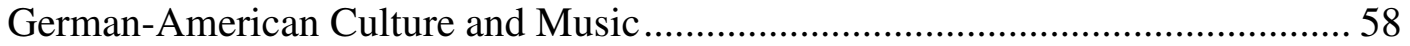

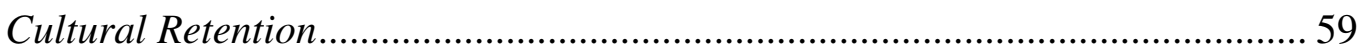

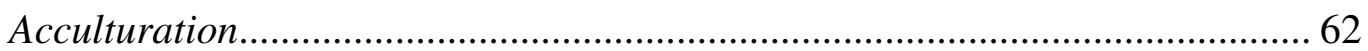

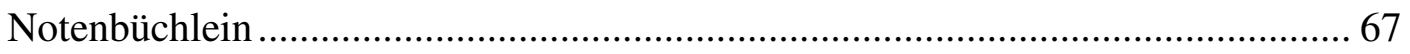

Chapter 4: The Germans and Shape-Note Hymnody in Western Maryland .............. 71

German-American Hymnody in Western Maryland.............................................. 71

Maria Brandstetter's Tunebook ........................................................................... 75

An Aside: SAMANTHRA ............................................................................ 84

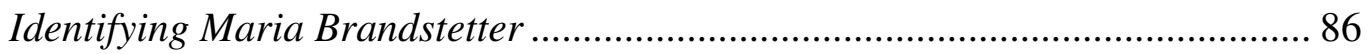

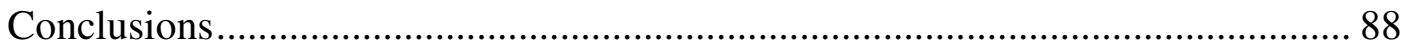

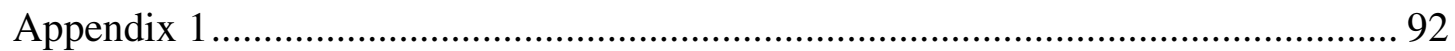

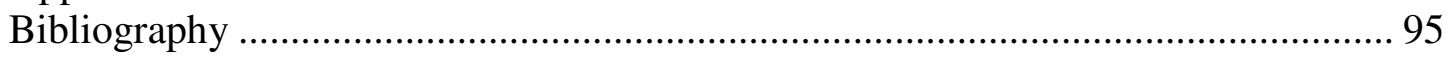

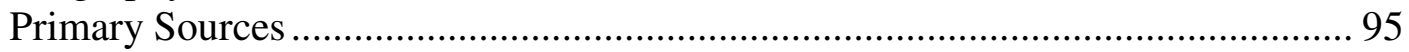

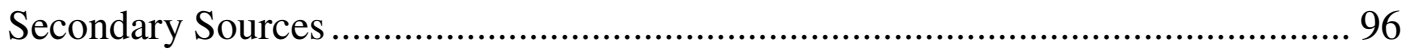




\section{List of Figures}

Figure 1 Title page of the Brandstetter tunebook. .................................................... 1

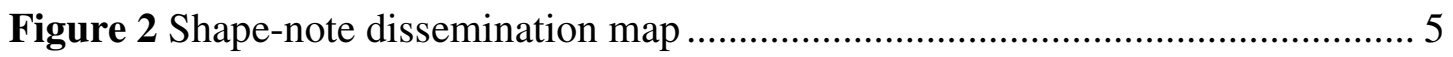

Figure 3 Augustine Herrman's 1670 map of Maryland .......................................... 25

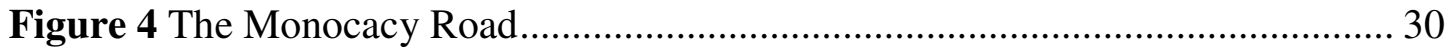

Figure 5 County map of Western Maryland in 1820 ........................................... 32

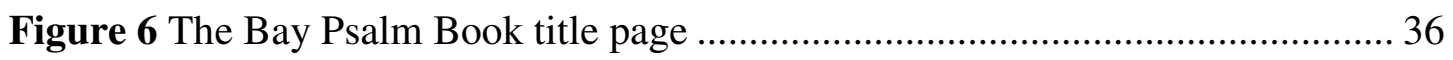

Figure 7 NORWICH in An Introduction to the Singing of Psalm-Tunes ................. 40

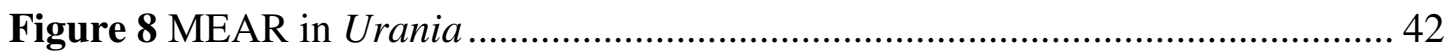

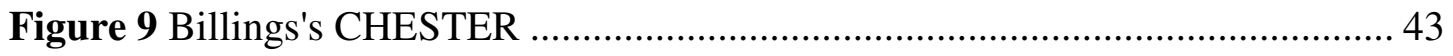

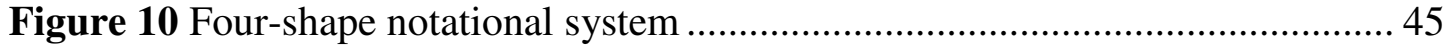

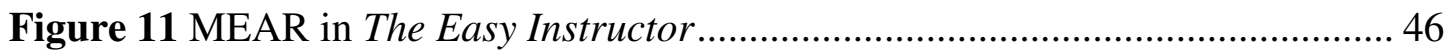

Figure 12 MEAR in Wyeth's Repository of Sacred Music ...................................... 50

Figure 13 MEAR in the Kentucky Harmony ........................................................ 53

Figure 14 MEAR in the Southern Harmony ....................................................... 55

Figure 15 Chorale in Choral-Buch fur die Erbauliche Lieder-Sammlung ................. 61

Figure 16 Title page of Joseph Doll's Leichter Unterricht ..................................... 64

Figure 17 Natural scale in Joseph Doll's Leichter Unterricht ................................. 66

Figure 18 The "rudiments of music," in the Brandstetter tunebook ........................ 78

Figure 19 Chorale tune in the Brandstetter tunebook........................................... 79

Figure 20 Fuging tune with a German text in the Brandstetter tunebook .................. 80

Figure 21 Three-part setting of a German text in the Brandstetter tunebook ............ 80

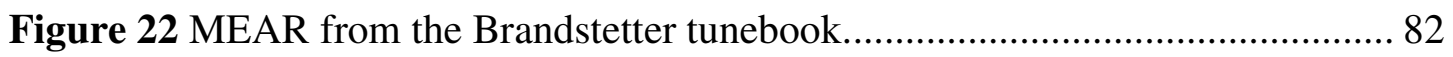

Figure 23 SAMANTHRA from the Supplement to the Kentucky Harmony............... 84

Figure 24 SAMANTHA in the Brandstetter Tunebook........................................ 84 


\section{Introduction}

In the Special Collections Division of the University of Maryland's Performing Arts Library there exists a small, oblong tunebook, measuring nineteen centimeters in length and ten centimeters along its spine. There is a single gathering of pages, bound by thread and surrounded by a grey cardboard cover. The cover has no ornamentation or title, but inside, the handwritten title page includes both a name and date, which suggest that the book was prepared in or around 1820 for a certain Maria Brandstetter of Washington County, Maryland (see fig. 1).

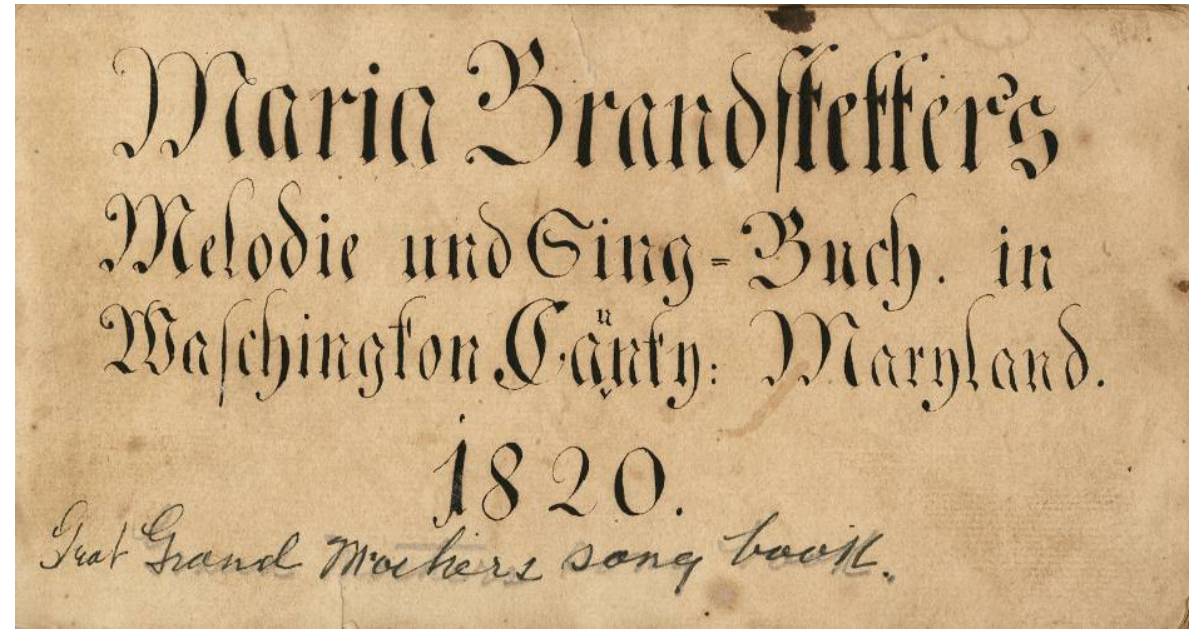

Figure 1: Title page of the Brandstetter tunebook.

Tunebooks are not unusual in the history of nineteenth-century American music, but this one has some surprising features. First, unlike the English-language tunebooks of compilers such as John Wyeth and Ananias Davisson, nearly half of the Brandstetter book's contents are chorales in German. There were other Germanlanguage tunebooks produced in early nineteenth-century America, but the Brandstetter book is curious in that the other half of its contents are American 
songs-hymns and fuging tunes in English - and the book's music is copied in shapenotation. As we shall see, this tunebook from the mountains of Western Maryland provides a window into the culture of a frontier community, and it also allows us to rethink the passage of shape-notes from their beginnings in Eastern Pennsylvania to the pivotal Shenandoah Valley in the early nineteenth-century. ${ }^{1}$ In this thesis, I will explain how the settlement of Maryland, particularly in its Western reaches by Germans from Pennsylvania, merges with the development and dissemination of shape-note hymnody.

As its story is usually told, America's home-grown, accessible notation in triangles, circles, squares, and diamonds moved southward from Philadelphia and Harrisburg, Pennsylvania to Harrisonburg and Winchester, Virginia in the 1810s. Here, Ananias Davisson's Harrisonburg print-shop became a major publishing center for shape-note hymnody, and the tradition quickly spread throughout the MidAtlantic and Southern United States. Once in the South, this specialized notation took on a life of its own, transforming itself into what is today commonly thought of as the Sacred Harp tradition.

As told, this story leaves a gaping geographical hole: nearly a hundred miles between compilers and singers in Harrisburg and those of the Northern Shenandoah Valley. The Brandstetter tunebook, however, suggests that Washington County, Maryland can fill in a portion of this gap, thus better explaining the migration of shape-note hymnody. There is, however, another important reason to give this

\footnotetext{
1 "Western Maryland" is used here to refer to the region containing the modern counties of Garrett, Allegany, Washington, and Frederick. Some writers also include Montgomery and Carroll counties, although this usage is less consistent.
} 
tunebook a closer look. Musicological studies often privilege large cities and urban areas, but in doing so the discipline can easily miss significant elements of nineteenth-century musical life. Examining the University of Maryland's Brandstetter tunebook draws a more complete picture of musical and ethnic culture in early nineteenth-century Western Maryland, an area that was (and to a degree, still is) isolated, rural, and largely unexamined by scholars. Thus, through the Brandstetter tunebook, we can better understand one community's musical life, and the role that community came to play in the most native musical tradition of the young United States.

\section{Literature Review}

As I shall demonstrate, the Brandstetter tunebook provides access to both the musical life of a German immigrant community in Western Maryland, and also to the migration route of shape-note music into the southern United States. Three areas of study were applied to my examination of this tunebook: 1) the history of American hymnody and the shape-note tradition, 2) the history of German-American sacred music, especially that written around the turn of the nineteenth century, and 3) the history of the early settlement of Maryland (particularly Western Maryland prior to the Civil War). Scholarship on these topics is vital to our understanding of the ethnic community whose music and migration created the Brandstetter tunebook and affected the dissemination of American sacred music in the late 1700s and early 1800 s. 


\section{Shape-Note Hymnody}

An examination of the Brandstetter tunebook allows for a reconsideration of the passage of the American shape-note tradition from Pennsylvania into the MidAtlantic region, and to the Harrisonburg shop of Ananias Davisson from which it would spread throughout the South. To this end, it is useful to consider how the spread of shape-notation has been understood in existing scholarship.

\section{George Pullen Jackson's 1933 White Spirituals in the Southern Uplands}

remains the seminal source concerning the history, people, and music associated with American hymnody. ${ }^{2}$ The story Jackson tells of the "fasola folk" and their tunebooks is invaluable, because it shows the dissemination of the tradition and the changes it underwent from its pre-Revolutionary New England roots to its popularity in the southern United States in the early twentieth century. Through his research, the significant tunebooks, composers, and compilers have been identified and, to a large degree, interconnected.

Jackson's main sources were the singers still performing shape-note music in the 1920s and 1930s and the printed tunebooks from which they sang. From the singers, he learned about the musical practices and culture of the communities that maintained shape-note conventions. From the publication history of the printed tunebooks, Jackson was able to piece together the development and history of American hymnody. The migration story he established took the music from New

${ }^{2}$ George Pullen Jackson, White Spirituals in the Southern Uplands (Chapel Hill: University of North Carolina Press, 1933). See also Jackson's Spiritual FolkSongs of Early America (New York: J. J. Augustin, 1937); Down-East Spirituals and Others (New York: J. J. Augustin, 1939); and Another Sheaf of White Spirituals (Gainesville: University of Florida Press, 1952). 
England to south of the Mason-Dixon Line. After the shape-note system was developed in Philadelphia, Jackson concluded that it spread from eastern Pennsylvania "southwestward into the Valley of Virginia," where Ananias Davisson resided (see fig. 2). ${ }^{3}$ Virtually all later studies of shape-note music rely on Jackson's explanation of this migration. The current study—focusing on the Brandstetter tunebook—will provide new details on how hymnody traveled through Western Maryland via its German population toward the Shenandoah Valley.

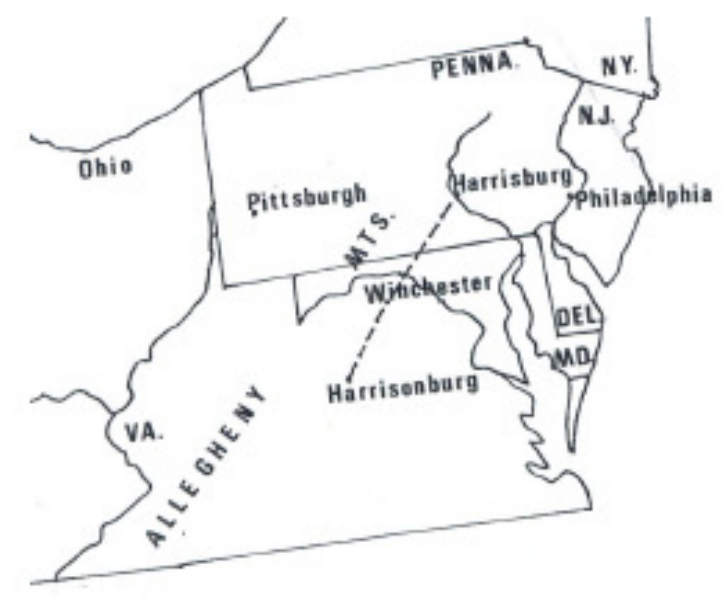

Figure 2: Dissemination map of shape notation, adapted from from Steel, "John Wyeth and the Development of Southern Hymnody," 368.

Many studies of shape-note music focus on specific geographic regions, and some of these can serve as a model for this thesis. Dissertations by both Harry Eskew and Rachel Harley target Virginia's Shenandoah Valley prior to the Civil War. ${ }^{4}$ Eskew explores the tunebooks of six compilers, and his findings on the two earliest

\footnotetext{
${ }^{3}$ Jackson, White Spirituals in the Southern Uplands, 23.

${ }^{4}$ Harry Lee Eskew, "Shape-Note Hymnody in the Shenandoah Valley, 18161860," (Ph.D. diss., Tulane University, 1966); Rachel Augusta Brett Harley, "Ananias Davisson: Southern Tune-Book Compiler (1780-1857)," (Ph.D. diss., University of Michigan, 1972).
} 
authors, Ananias Davisson and Joseph Funk (along with Harley's work on Davisson), were most significant to this study. Like Jackson, both scholars approached the subject from the printed tunebooks themselves, and as a result accepted Jackson's statement that shape-note hymnody came to the Valley from Pennsylvania. Eskew's work serves mostly as a survey of the tunebooks, compiling their contents into measurable data. Harley's research, though shedding light on the uncertain (and still incomplete) biography of Davisson, adds little to Eskew's study. Given that these Shenandoah Valley compilers received the American hymn tradition from Pennsylvania, the question of just how they obtained their musical education and hymns is significant. Although Eskew and Harley give this matter some attention, it is not a central concern for either scholar, and they do not change how we understand the dissemination story between Pennsylvania and Virginia.

Related to the question of how the pivotal compiler Ananias Davisson came into contact with shape-note hymnody are two separate studies conducted by Charles Hamm and James Scholten. Rather than focusing on tunebooks and compilers, Hamm and Scholten uncovered the lives of Lucius and Amzi Chapin, two brothers, composers, and singing masters active in Virginia, South Carolina, Kentucky, and Pennsylvania. ${ }^{5}$ A number of their tunes were printed in the early nineteenth century, and some remain popular to this day. Since there is evidence that the Chapins were teaching in the Shenandoah Valley around the time when Davisson may have attended singing-school, it has been theorized that they first introduced the music to

${ }^{5}$ Charles Hamm, "The Chapins and Sacred Music in the South and West," Journal of Research in Music Education 8 (Autumn 1960): 91-98; James W. Scholten, "Amzi Chapin: Frontier Singing Master and Folk Hymn Composer," Journal of Research in Music Education 23 (Summer 1975): 109-119. 
the would-be compiler. ${ }^{6}$ But any relationship with Davisson is purely speculative, because there is no evidence connecting the three men. As we shall see, the Brandstetter tunebook suggests that the music and sources that Davisson would need were already moving across the Mason-Dixon Line in the hands of German settlers.

Contemporary studies of shape-note music often center on the history of one of the most popular shape-note collections, The Sacred Harp. This book was first published in 1844, and many editions later, remains in regular use today. ${ }^{7}$ Two scholars who have published important large works on the subject are Buell Cobb and John Bealle. ${ }^{8}$ Cobb's goal is partially to update the story first told by Jackson and focus it on the continuing Sacred Harp tradition. His book condenses much of what Jackson had uncovered, and provides a streamlined history of The Sacred Harp. Bealle writes in a similar vein, covering a lot of the same ground travelled by Jackson and Cobb before him. What he adds is a study of the "Sacred Harp Revival," believing that the scholarship on The Sacred Harp has paved the way for the revival movement. Bealle finds that "the custodians of Sacred Harp have constructed singing as a tradition," and the Sacred Harp Revival was "based in part on traditional singers'

\footnotetext{
${ }^{6}$ Hamm, 97.
}

${ }^{7}$ First edition: B. F. White and E. J. King, The Sacred Harp, $1^{\text {st }}$ edition (Philadelphia: T. K. Collins, Jr., 1844); most recent edition: Hugh McGraw, ed. et al., The Sacred Harp, 1991 revision (Bremen, GA: Sacred Harp Pub. Co., 1991).

${ }^{8}$ Buell Cobb, The Sacred Harp: A Tradition and Its Music (Athens: The University of Georgia Press, 1978); John Bealle, Public Worship, Private Faith: Sacred Harp and American Folksong (Athens: The University of Georgia Press, 1997). 
own cultural constructions of Sacred Harp and in part on the heightened value of folk traditions that circulated in mainstream America" in the post World War II era. ${ }^{9}$

Cobb and Bealle necessarily provide a history of the shape-note tradition that led to the eventual compilation of The Sacred Harp. Following the story told by Jackson, both authors take the music and its materials from Pennsylvania west to Ohio and south to the Shenandoah Valley. The transmission of the repertory from Eastern Pennsylvania to Virginia and the identification of the individuals who participated in it remain unexamined.

The most recent musicologist to focus on the shape-note tradition is David Warren Steel. His 2010 The Makers of the Sacred Harp provides background information about the people most involved in that tunebook's history in the years leading up to and since its initial printing. ${ }^{10}$ Because of this focus, the early history of the shape-note tradition is given little attention. A 1988 article by Steel is, however, an important contribution to this latter topic. In it, the author examines the first tunebook published by John Wyeth in Harrisburg, Pennsylvania: Wyeth's Repository of Sacred Music. As he demonstrates, this tunebook will play a crucial role in the migration of shape-note music into the Mid-Atlantic and Southern states. While Steel shows the connection between this book and those of later compilers, he continues to work within the story first told by Jackson where the initial connection is between eastern Pennsylvania and the Shenandoah Valley. Steel makes no mention of

\footnotetext{
${ }^{9}$ Bealle, 187 and 242.

${ }^{10}$ David Warren Steel with Richard H. Hulan, The Makers of the Sacred Harp (Urbana: University of Illinois Press, 2010).
} 
Maryland and only hints at the German connection to shape-note dissemination in a footnote. $^{11}$

The field of ethnomusicology has also contributed to the study of shape-note hymnody, and Kiri Miller's 2008 book serves as a model of that discipline's approach. Miller identifies a number of social groups who are brought together despite "generational, religious, political, and geographical differences [which] would ordinarily prevent these people from crossing paths at all, let alone [form] a tight-knit community." 12 She then examines why it is that singers travel great distances to take part in shape-note singing and thus find themselves bound together across diverse cultural lines. Miller finds that modern singers are unified by a nostalgia connected to the tradition, though each singer may have differing personal ideas of what the Sacred Harp tradition means. Miller sees her book as "first and foremost an ethnography of a musical community." 13

The community that gave rise to the Brandstetter tunebook is, of course, long gone, but we can nonetheless borrow Miller's methods of exploring a community's decisions concerning musical content and performance. Although ethnomusicological studies, such as Miller's, are aware of scholarship on the rise of modern shape-note communities, they are not usually interested in the history of shape-note singing. What can be taken from their methodology is the focus on the culture of a specific

${ }^{11}$ David Warren Steel, "John Wyeth and the Development of Southern Folk Hymnody," in Music from the Middle Ages Through the Twentieth Century, 357-74 (New York: Gordon and Breach Science Publishers S.A., 1988), 362.

${ }^{12}$ Kiri Miller, Traveling Home: Sacred Harp Singing and American Pluralism (Chicago: University of Illinois Press, 2008), 4.

${ }^{13}$ Ibid, 20. 
community of singers. This study will center on a German community of Western Maryland in the decades around 1800, and examine how their particular heritage brought shape-note hymnody into the region.

\section{German-American Sacred Music}

Given that half of the Brandstetter tunebook's contents are German chorales, it is useful to understand the religious tradition from which these works were drawn. Four authors who have dealt with the music of German immigrants in the MidAtlantic region are particularly important in this respect. Daniel Grimminger's dissertation, "Pennsylvania Dutch Tune and Chorale Books in the Early Republic: Music as a Medium of Cultural Assimilation," explores the religious and musical practices of the largest ethnic minority found within the early English-speaking colonies: the Pennsylvania Dutch. German immigrants arriving in America often formed isolated pockets, setting themselves apart from the Anglo-American majority. A number of German Christian denominations practiced such a "theology of separation.” These Sektenleute (Sectarian People) made a point of removing themselves from the larger population, maintaining a culture absent of other religious and ethnic influences. ${ }^{14}$ Conversely, the Kirchenleute-which included members of the Lutheran and German Reformed churches-believed that being a part of society and performing civic duties were "good works of God," leaving open the possibility for cultural exchange with their Anglo-American neighbors. Because of this cultural

\footnotetext{
${ }^{14}$ The Sektenleute includes descendants of the Anabaptist reformers who maintain a presence in the United States today. They include the Amish, Mennonite, Ephrata, and Cloister sects.
} 
exchange—which led to items like the Brandstetter tunebook—-the Kirchenleute are a main interest to this thesis. ${ }^{15}$

Also useful is Grimminger's analysis of early German-American tune and chorale books. By compiling information on the books' layouts, purposes, audiences, language, and music, he sheds light on the connection between the American sacred tunebook tradition and its German counterpart. He notes three types of GermanAmerican printed music books from the late eighteenth century into the late $1860 \mathrm{~s}$. The first type consists of "retentive tune and chorale books," whose characteristics most closely mirror the chorale and sacred song traditions of Germany. These books retain the German language in their texts and include chorale tunes arranged in twopart figured bass. Allowing for some Anglo-American influence, "adaptive tunebooks" (the second type) contain some American (or American-sounding) tunes, three- to four-voice textures, fuging tunes, and shape-notation. These books often contain a number of chorale tunes and continue to employ the German language, despite the presence of American melodies. The third type are books demonstrating "amalgamation," where German printers published tunebooks in the same vein as their American counterparts in language, content, and format. ${ }^{16}$ Since this final type of German-American tunebook comes at a date outside the bounds of this study, the retentive and adaptive tunebooks will be our main interest.

Though Grimminger has limited himself to those books produced by or for the Pennsylvania Dutch, his information is invaluable to scholars interested in a more

${ }^{15}$ Daniel J. Grimminger, "Pennsylvania Dutch Tune and Chorale Books in the Early Republic: Music as a Medium of Cultural Assimilation," (Ph.D. diss., Claremont Graduate University, 2002), 13-17.

${ }^{16}$ Ibid., 81-87, 143-146, 181-182. 
complete story of the evolution of American tunebooks, particularly as those books moved south and west into the Shenandoah and Ohio Valleys. While Grimminger's research focuses on tune and chorale books as primary sources, his aim is to gain a greater understanding of the development of German-American cultural identity. For him, the books are a medium through which the opposing forces of ethnic retention and assimilation within the Pennsylvania Dutch were triggered, suppressed, and recorded. He does not, however, use this research to change our current view of American tunebook dissemination.

Another scholar who is concerned with the written musical tradition of the Pennsylvania Dutch is Susan Gross. Rather than looking at published collections, however, Gross focuses on small manuscript tunebooks, referring to them as Notenbüchlein. ${ }^{17}$ The books Gross worked with were produced by a specific group of Mennonites living in southeastern Pennsylvania in the late eighteenth and nineteenth centuries. From her analysis, Gross determined that the books were personalized gifts, created by music teachers for their students. The contents of the Notenbüchlein are mostly German hymns, some specific to the Mennonite tradition and others connected to the larger chorale repertoire. Beginning in the second decade of the nineteenth century, some of the books came to contain American music or suggest American influence-such as the use of shape-notes-alongside German music. This combination reflects a situation much like that observed by Grimminger, where German musical practices were influenced by the dominant Anglo-American culture

${ }^{17}$ Suzanne Gross, "Hymnody of Eastern Pennsylvania German Mennonite Communities: Notenbüchlein (manuscript songbooks) from 1780 to 1835," (Ph.D. diss., University of Maryland, 1994). 
of the New World. Though Gross's studies do not move outside this small community of Pennsylvania Mennonites, the characteristics she observes in the Notenbüchlein are strikingly similar to aspects of the Brandstetter tunebook. These similarities shed light on the possible history of the Western Maryland tunebook and also suggest new possibilities for the use of Notenbüchlein by the broader German-American immigrant culture in the United States before and during the 1800s.

Paul Westermeyer explored the subject of German-American sacred music in his dissertation, "What Shall We Sing in a Foreign Land? Theology and Cultic Song in the German Reformed and Lutheran Churches of Pennsylvania, 1830-1900."18 Westermeyer's work focuses on the group Grimminger referred to as Kirchenleute and makes distinctions between the Lutheran and German Reformed churches, and specifically their musical heritage. Through a study of hymnals used in both churches over a span of nearly two hundred years, Westermeyer shows how the two denominations differ only slightly from each other in their handling of musical materials. He finds that both churches experienced significant loss of their musical culture during the nineteenth century: the Lutheran tradition faded dramatically, while the German Reformed church nearly "obliterated the German chorale tune heritage along with the German chorale texts. ${ }^{, 19}$ Still, the two churches' histories parallel one and other, and despite conscious efforts to maintain a German heritage, the English

${ }^{18}$ Paul Westermeyer, "What Shall We Sing in a Foreign Land? Theology and Cultic Song in the German Reformed and Lutheran Churches of Pennsylvania, 18301900," (Ph.D. diss., University of Chicago, 1978).

${ }^{19}$ Westermeyer, "The Evolution of the Music of German American Protestants in Their Hymnody: A Case Study from an American Perspective," in Music in American Religious Experience, ed. Bohlman, Blumhofer, and Chow (New York: Oxford University Press, 2006), 162. 
style became a part of both denominations' hymnals. Westermeyer also provides a case study of a particular pastor/hymn composer who, despite attempting to write melodies reflecting the German chorale heritage, included melodic turns and leaps more characteristic of the Anglo-American tunes whose influence he wanted to avoid. This intriguing case suggests that the movement toward a new American style may have occurred partially by mistake, the result of an almost subconscious effect. ${ }^{20}$

Westermeyer's work demonstrates that the Kirchenleute, though comprised of two different groups, followed the same musical path; one leading to a convergence of the German chorale tradition and the still developing American sacred song style. He does not, however, approach this research from the perspective of American hymnody. Like Grimminger, Westermeyer is more concerned with the dilution of German heritage, rather than the incorporation of American styles into the German tradition.

An article by Edward C. Wolf, "Two Divergent Traditions of GermanAmerican Hymnody in Maryland circa 1800," provides a third study of early German-American sacred music in the Mid-Atlantic, now focusing on the state of Maryland. Wolf's research is significant in that he is one of the few scholars who has given serious attention to early hymnody and German sacred music within the state. Wolf illustrates two divergent courses in German-American sacred music, with the key element being urban versus rural lifestyles. He suggests that while the urban German population of Baltimore maintained close musical links with the European homeland, the rural population more readily developed a music that merged German

${ }^{20}$ Ibid, 166-68. 
and American hymnody. In the process, Wolf sheds light on another early Maryland tunebook created for Germans in Western Maryland: Adam Arnold's 1803 Geistliche Ton-Kunst. Wolf uses this tunebook to discuss the characteristics of rural GermanAmerican hymnody in contrast with the music used by the Germans in the urban setting of Baltimore. His findings concerning urban versus rural musical traditions "represent a basic development in what we recognize today as a significant part of the history of American hymnody and church music." ${ }^{21}$ Wolf, however, makes no attempt to show how his observations fit into or change our understanding of the history and dissemination of American hymnody. He simply states that this occurrence in German-American hymnody is a paradigm for American sacred music.

\section{The German Settlement of Maryland}

The Brandstetter tunebook was the product of the most significant ethnic community to settle Western Maryland: German immigrants; but the history of this settlement has not been given much attention by scholars. ${ }^{22}$ The most useful studies are those by Daniel W. Nead and Dieter Cunz. ${ }^{23}$ Both of these studies are quite dated,

${ }^{21}$ Edward C. Wolf, "Two Divergent Traditions of German-American Hymnody in Maryland circa 1800," American Music 3 (Autumn 1985), 308.

${ }^{22}$ The first large works to touch on the subject were Thomas J. Scharf, History of Western Maryland (Philadelphia: L. H. Everts, 1882); and Thomas J. C. Williams, The History of Washington County, Maryland (Chambersburg, PA: J. M. Runk \& L. R. Titsworth, 1906). Both are monumental surveys, but too broad in scope to be particularly helpful to this thesis.

${ }^{23}$ Daniel W. Nead, Maryland's German Heritage: Daniel Wunderlich Nead's History, Don Heinrich Tolzmann, ed., (Bowie, MD: Heritage Books, 1994); first published as The Pennsylvania-German in the Settlement of Maryland (Lancaster, PA: Press of the New Era Printing Company, 1914). Dieter Cunz, The Maryland Germans (Princeton: Princeton University Press, 1948). 
but they are the only sources to provide thorough histories of German migration into Maryland. Nead focuses on the German role in the state's formation, and also provides a background history of Maryland prior to German settlement. The strength of this work is the author's consistent use of primary sources, most of which are government documents, often provided in full text. Also useful is the focus Nead gives to the German settlers in Western Maryland, the community that produced the Brandstetter tunebook.

Dieter Cunz's The Maryland Germans is a larger, more thorough work. Like Nead, he provides a history of Maryland before the German migration and then spotlights the state's German heritage. Unlike Nead, Cunz's focus is on the German culture within the entire state. Cunz's study includes useful biographical sketches and discussion of social and leisure activities such as travel, entertainment, and printing. Though the information concerning music is limited to the large choral societies of Baltimore, what is gained is a better understanding of the types of music employed by German immigrants, as well as of how people and products moved through the area and between states. Since the Brandstetter tunebook provides new evidence for a reconsideration of both musical life and musical migration, both elements of Cunz's study are useful.

A more recent study of German immigrants in Maryland is Chelsea Clarke's 2009 thesis, "Jacob Engelbrecht: An Example of German-American Identity in Nineteenth-Century Maryland," which leans heavily on a 1981 dissertation by 
Elizabeth Kessel. ${ }^{24}$ While both studies center on the German population of Western Maryland, neither adds significantly to the histories found in Nead and Cunz. Kessel suggests that some of the Germans immigrating to Western Maryland came from Europe through the port of Annapolis in the late eighteenth and early nineteenth century, but admits that this hypothesis is difficult to confirm. Kessel also focuses specifically on Frederick County, leaving the greater portion of Western Maryland, including the area that gave rise to the Brandstetter tunebook, relatively untouched. Clarke on the other hand does examine Washington County, but does so mainly through a case study of an individual. This approach is useful, but in the end the histories provided by Nead and Cunz are most important in explaining how the German immigrant population of Western Maryland helped to spread hymnody throughout the American South.

These three fields of study (the development of shape-notation, the culture of German-American hymnody, and the history of Germans in Maryland) have already begun to paint a picture of musical life in early nineteenth-century Maryland. None of this scholarship has fully explored the cultural life of Washington County, however, nor has it connected that life to the dissemination of American shape-note singing. The tunebook compiled for Maria Brandstetter, however, allows us to accomplish both tasks, thus providing insight into the movement of American hymnody in the

${ }^{24}$ Chelsea L. Clarke, "Jacob Engelbrecht: An Example of German-American Identity in Nineteenth Century Maryland." (MA thesis, University of Maryland, Baltimore County, 2009). Elizabeth Kessel, "Germans on the Maryland Frontier: A Social History of Frederick County, Maryland, 1730-1800” (Ph.D. diss., Rice University, 1981). 
Mid-Atlantic region and sharpening our view of that music's history and dissemination. 


\section{Chapter 1: The Settlement of Maryland}

Since the Brandstetter tunebook dates back to early nineteenth-century Western Maryland and shows the influence of both German and American music, it is important to understand the history of the area and why a German population existed there. The Germans who settled Maryland's western counties arrived for different reasons than the English who first settled in the state's tidewater region. An examination of the path that brought German settlers to Western Maryland will help to explain the contents of the Brandstetter tunebook, and show how these Germans are connected to the dissemination of shape-note hymnody.

\section{Calvert's Colony along the Chesapeake}

The colony of Maryland was the plan of Sir George Calvert (1579-1632), a member of the English government and close friend of King James I. His loyal service and relationship with the king led to Calvert's rise through the English ranks, and he eventually received a substantial annual pension along with subsidies on imported raw silk. ${ }^{1}$ As was typical among wealthy and high-ranking Europeans of the time, Calvert was drawn to the economic potential of the New World. A shareholder in the East India and Virginia companies, Calvert learned the perils and possibilities afforded by natural riches across the Atlantic. His 1625 conversion to Catholicism caused Calvert to resign from the government and retract the Oath of Supremacy to his king. Despite these actions, James I remained a grateful friend and granted Calvert the title Baron of Baltimore (referring to Calvert's manor of Baltimore in Ireland).

${ }^{1}$ Robert J. Brugger, Maryland: A Middle Temperament 1634-1980 (Baltimore: The Johns Hopkins University Press, 1988), 4. 
As a Protestant in the English government, Calvert had attempted to create a peaceful alliance between Britain and Catholic Spain, a move that demonstrated his desire to bring Christians of differing denominations together. Though the effort proved futile, his spiritual conversion inspired Calvert to found a settlement in the New World, "where religious liberty would be secured to all the inhabitants." 2 The new colony would, of course, also serve Calvert's economic ambitions and grant him power to rule over what he hoped would be a sizeable population and expanse of land.

Calvert first tried to found a settlement in Newfoundland, but following the summer of 1629 he decided that the cold climate and rocky landscape was unfit for colonization. He wrote to King Charles I, James's successor, inquiring about a grant in the northern Chesapeake near what had recently become Virginia. Though Virginian officials worked against Calvert, the king signed a charter establishing the new colony of Maryland in June of 1632. George Calvert, however, had succumbed to poor health two months earlier, and so the charter was granted to his eldest son and successor, Cecil Calvert, the second Lord Baltimore. $^{3}$

Cecil Calvert planned the colonizing voyage to Maryland amidst a tense religious and political atmosphere in England, but by September of 1633 he had organized a group of wealthy gentlemen, to be joined by over a hundred yeomen and laborers. Calvert's upper class settlers were mostly the sons of Catholic gentry, while his laborers were largely Protestants. As the expedition set off in November of 1633, the number of settlers totaled between 130 and 140, but Cecil Calvert was not among

\footnotetext{
${ }^{2}$ Nead, 6.

${ }^{3}$ Brugger, 5.
} 
them. Due to turmoil in England he sent his brother, Leonard Calvert, to act in his place as governor. ${ }^{4}$

Cecil's written instructions to Leonard show some of Lord Baltimore's concerns. He ordered Leonard to have an Anglican member of the expedition visit the Virginia colony to establish a peaceful relationship between the neighboring settlements. He further encouraged them to build a rapport with the Indians in the area and attempt to convert the tribes to Christianity. Calvert also promoted the interests of the colonists, wanting them to make gains from their toils and live comfortably. Most significantly, Cecil counseled Leonard and the other expedition leaders to maintain religious tolerance and peace between Catholics and Protestants; all were guaranteed freedom to practice their religion, and laws governing land ownership were not to be based on spiritual beliefs. With plans in hand, the voyage landed within the Maryland land grant in March of $1634 .^{5}$

Having learned from John Smith's published narratives concerning the early Virginia colony, these Maryland settlers planned better and further in advance, making their transition to life in the New World much smoother than that of their Virginian neighbors. Calvert's men built a central “town” called St. Mary's, and set to working the land, preparing both for survival and economic advancement. The charter

${ }^{4}$ Ibid., 6. The turmoil surrounding Calvert was multifaceted: he had to defend the Maryland charter against attacks from Virginia officials in England; shortly before the expedition left, King Charles had dissolved Parliament and the events leading to the English Civil War were underway (as a friend of Charles, Calvert had to convince Parliamentarians of his loyalty); and the Church of England's persecution of Puritans and Catholics had increased (as a Catholic, Calvert's colony became a refuge for English Catholics, forcing Calvert to again defend his loyalty to Protestant England to maintain possession of the Maryland charter).

${ }^{5}$ Ibid., 6-9. 
granted to Calvert was liberal, essentially creating a fiefdom: Maryland represented a royal gift to Lord Baltimore, who served as proprietor of the land, answering only to the king. Calvert's plan was to duplicate the aristocratic, manorial community of old England by allotting large plots of land to settlers who brought servants with them to begin plantations in the colony. This of course guaranteed a flock of wealthy settlers, as only they could afford to transport servants. By law, journeymen who brought five men between the ages of sixteen and fifty received two thousand acres in 1634 (a gift lowered to one thousand in 1635). The allotments decreased with the number of servants, so settlers bringing less than five received only one hundred acres for themselves and one hundred more acres per additional servant. ${ }^{6}$

The fertile land of Maryland was unlike anything the settlers were used to in England and grain yields were immediately high enough for trading. Despite this, the crop on the minds of early Marylanders was tobacco. Virginia's colony had proven the value of the plant and a marketing system was already available connecting the Chesapeake settlements to England. On Maryland's shores, tobacco grew readily and in the year 1639 a full one hundred thousand pounds was produced. For the first halfcentury of Maryland's existence tobacco served as the main currency, with a bill aimed to begin the use of coin presented only in $1688 .^{7}$

Due to the focus on tobacco farming, as well as a general fear of indigenous peoples, the western regions of Maryland had remained relatively untouched. The tobacco trade encouraged growers to remain in close proximity to major waterways as staying along the coast allowed them to move more product over shorter distances,

\footnotetext{
${ }^{6}$ Ibid., 12-14.

${ }^{7}$ Ibid., 37.
} 
keeping their leaves fresh and in constant supply. Fear of the region's indigenous population also prevented a rapid spread west. The native communities in the colony's western hills would set huge fires to run game out of the forest, giving a hunting advantage to the Indians. Early European settlers reported observing these enormous fires miles off the Atlantic coast, a sight that caused considerable and understandable alarm among ignorant voyagers. Early travelers in the west and north of Maryland also sent back reports of barren hills and rocky soil that would be of little benefit to people hoping to colonize the region. ${ }^{8}$ It is quite possible that these large fires contributed to the landscape, as adventurers came upon large sections of burnt, empty land.

Because of tobacco's high market-value in the mid-1630s (the years of Maryland's initial colonization) the Chesapeake settlers had little reason to journey away from the bay area. But by the 1680s, overproduction had caused prices to drop by some fifty-percent from the levels seen just thirty years earlier. ${ }^{9}$ But Maryland settlers had known only one way of life and for the colony's first century—despite falling prices - tobacco remained the main cash crop, and migration beyond the fertile tidewater region was limited. In 1748, after a number of hopeful suggestions by the Maryland government, a law was finally passed limiting tobacco cultivation and encouraging the planting of grain crops. ${ }^{10}$ The impact of this shift was significant. Tobacco overproduction had damaged the tidewater soil and made grain farming almost impossibly difficult. If the Maryland colony hoped to grow, the population had

\footnotetext{
${ }^{8}$ Ibid., 67.

${ }^{9}$ Ibid., 35-37.

${ }^{10} \mathrm{Cunz}, 47$.
} 
to expand beyond the Atlantic and Chesapeake coasts into the unexplored backcountry. The opening of Western Maryland was made possible by a few ambitious settlers, an inviting government, and a migrating group from the European mainland.

\section{Uncovering the West}

To move forward with the story of Western Maryland, we must first look back to the events that made the region's settlement possible. For the first 150 years of Maryland's life, the colony was tangled in issues concerning boundaries, which further added to the difficulty of expanding beyond the tidewater region. Part of this struggle was due to the lack of a map detailing the land chartered to Calvert. To answer this problem, Augustine Herrman, the first Marylander with a Germanic background to rise above anonymity, approached Lord Baltimore with a solution in $1660 .^{11}$

Herrman offered to draw a map of the entire province for Cecil Calvert, receiving a sizeable plot of land in return. Calvert quickly accepted and had 5,000 acres granted to Herrman at the northern point of the Chesapeake. Over the next ten years Herrman surveyed and sketched the land, presenting Lord Baltimore with a final draft in 1670 (see fig. 3). Baltimore was clearly happy with Herrman's work, presenting him with further land grants totaling 25,000 acres. The map he produced served as the main resource used by Calvert in land disputes to the east, west, and

${ }^{11}$ The question of Herrman's nationality has been argued often. His origin in Bohemia is known and further discussion of his background can be found in Cunz, 12-13. 
south; his work even found use in an 1873 report concerning the boundary between Maryland and Virginia. ${ }^{12}$

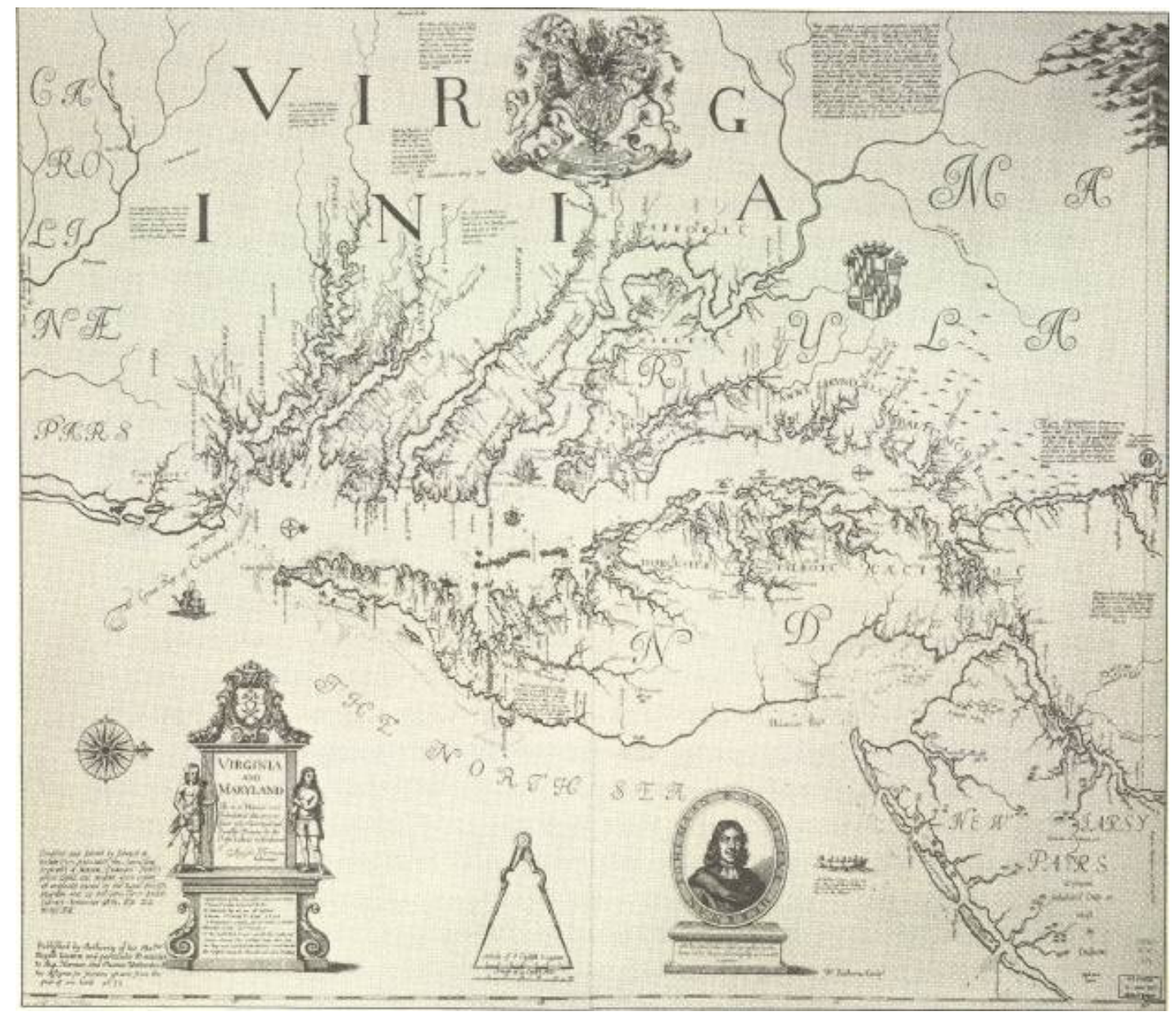

Figure 3 Augustine Herrman's map, from Brugger, 32.

Though Herrman's map revealed some parts of the province, the far western reaches remained a mystery to the government and citizens of Maryland. It was not until the ambitious Daniel Dulany entered into the untraveled lands of Western Maryland that a clearer view of the "backcountry" became available. Dulany (16851753), an Irishman by birth, arrived in Maryland in 1703 as an indentured servant,

${ }^{12}$ Ibid., 16-17, 23-24. 
working in the law office of George Plater. Upon completing his indenture, Dulany entered into Maryland politics, at one point holding the post of attorney general. ${ }^{13}$ In response to the colony's need for economic growth—and British demand for iron— Dulany turned to the backcountry, where deposits of iron, copper, and limestone had been reported. Here there was a small village along the northwestern estuary of the Patapsco River, named Baltimore Town, which soon began to thrive thanks to its productive iron mills. It was this town of Baltimore that pointed Dulany toward the northern and western frontiers. ${ }^{14}$

Dulany's interest in the region coincided with the desire of Charles Calvert, the fifth Lord Baltimore, to avoid land disputes with neighboring colonies. Calvert believed that placing settlers loyal to the province of Maryland in the region would affirm his control of the area. Dulany began surveying and granting patents for land above the Potomac and along the west bank of the Monocacy River. Following a 1732 visit to the colony by Calvert, trouble with Virginia arose as her government began making grants on disputed lands along the upper Potomac. According to its charter, Maryland's southwestern edge was the Potomac River, but the whereabouts of the river's source was unknown, making the waterway's path uncertain. In 1744 Dulany, who continued to buy and rent lands in Western Maryland, made a trip up the

\footnotetext{
${ }^{13}$ Brugger, 61.
}

${ }^{14}$ In 1752, Baltimore Town had twenty-five buildings, being mostly wooden houses. The village eventually expanded and its population grew, later shortening its name simply to Baltimore, reaching its peak population of one million residents in 1950; ibid., 66-67. 
southern branch of the Potomac, and wrote back to Lord Baltimore that the region "had rich soil, timber, stone for building, some marble, and was "very healthy.",15

Having travelled and surveyed the area, Dulany continued to patent land, eventually owning almost twenty thousand acres. He began to offer one hundred to three hundred acre farms at modest prices (at a loss in the beginning), hoping to persuade migrating families to settle the backcountry of Maryland. A significant portion of his targeted market was travelers crossing through Western Maryland on their way to Virginia. The settlers, highly prized for their "superior husbandry, sobriety, and prosperity," were German farmers from Pennsylvania, and Dulany believed them "the fittest people that can be to Settle a New Country.",16

\section{The Arrival of the Germans}

Aside from Augustine Herrman, no other Germans had made a significant impact on Maryland's early settlement, and there is little indication of Germans in the area for nearly three-quarters of a century after Calvert's original charter was signed. But as the seventeenth-century drew to a close, violence and conflicts within Germany pushed a large portion of her people into Britain and then across the Atlantic to seek a new beginning. ${ }^{17}$ The first organized group of German immigrants

${ }^{15}$ Lord Baltimore; quoted in ibid., 67-69.

${ }^{16}$ Ibid., 69; remark quoted in Frank W. Porter III, "From Backcountry to County: The Delayed Settlement of Western Maryland," Maryland Historical Magazine 70 (1975): 344-45.

${ }^{17}$ Nead, 27-29. 
landed in Philadelphia's harbor in October of 1683, and in the decades that followed, a continuous flow of German colonists began to populate the Pennsylvania territory. ${ }^{18}$

The German population rose so quickly that Pennsylvania officials became alarmed. Between 1727—when closer immigration records began to be kept-and 1775 , at least 68,800 German emigrants entered the colony. ${ }^{19}$ The provincial government approached the situation by having German arrivals move away from established English settlements; either into the northern reaches of the territory or toward the Susquehanna River (to the west and southwest). But they were not to cross the boundary into Maryland - this kept settlers paying taxes to Penn's colony while also creating a human barricade between the more populous English areas within the province and the hostile Indian presence in the outlying lands. As the Germans moved further into the frontier regions, English oversight and authority lessened, and isolated pockets of people preserving Germanic culture were generated.

Of course, the boundary between Pennsylvania and Maryland was uncertain, even amongst the proprietors of the two colonies, and this confusion led to complications for migrating German farmers. Even though Lord Baltimore had openly encouraged settlement of the northern and western parts of Maryland, trouble arose when German farmers crossed the Susquehanna and moved into disputed land; land they believed to be within the Pennsylvania borders. In both Maryland and Pennsylvania, authorities sought taxes and allegiance to their respective colonies and settlers in the region were plagued by the dispute between the two sides. These
${ }^{18}$ Cunz, 11.
${ }^{19}$ Nead, 31. 
disputes sometimes turned violent, catching German farmers in the crosshairs. ${ }^{20}$ One Marylander, Thomas Cresap, an energetic supporter of the Calverts, policed the area with great vigor and drove Pennsylvanian Germans out of their homes if they crossed what he believed to be the Maryland border. After years of torment, the German farmers wanted little to do with Maryland, its government, and the likes of Cresap. ${ }^{21}$

More intentional movement by Pennsylvania Germans into Maryland came as a result of Indian attacks. In a sense the Germans had accepted their role as buffers against hostile Indians, but they expected some support from the authorities in return. Back-country communities petitioned the Quaker government for protection, but their pleas continually went unanswered. Jost Hite, a signer of a 1728 petition from a community living in Colebrook Valley, took a proactive stance and began an important progression southward, seeking safety from the attacks. ${ }^{22}$

In 1731, Hite bought land in the Northern Shenandoah Valley where a small German community, migrating from North Carolina, had been forming since $1714 .^{23}$ Following an old Indian trail which crossed the Susquehanna and Monocacy rivers known as the "Monocacy Road," Hite travelled through Western Maryland and reached his new home near present-day Winchester, Virginia. Sixteen other families, either blood relatives or friends of Hite, made the journey as well. The success of the German colony in Virginia and the persuasive powers of its members drew more

${ }^{20}$ Cunz, 48.

${ }^{21}$ Cresap was actually arrested by Pennsylvania authorities in 1736; when brought to Philadelphia, Cresap exclaimed, "Damn it, Aston, this is one of the Prettyst Towns in Maryland!" For more information concerning Thomas Cresap, see Nead, 128-32; Cunz, 49-51; Brugger 68-69.

\footnotetext{
${ }^{22}$ Nead, 39-41.

${ }^{23}$ Cunz, 57.
} 
interest from Pennsylvania frontier families, and started a large migration from Pennsylvania to Virginia.

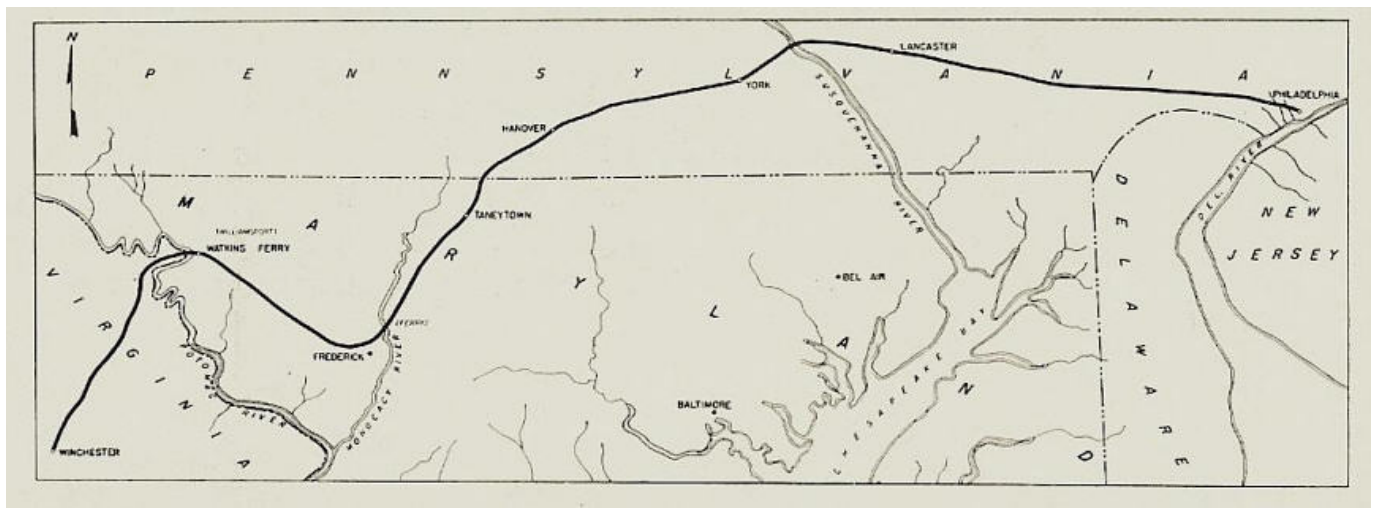

Figure 4: The Monocacy Road, from John McGrain, "The Wagon Roads of Western Maryland, http://www.wmdhistory.org/general/wagon-roads-western-maryland-mcgrain1.php.

Maryland officials took note of the movement through their western reaches.

Falling tobacco prices had Maryland officials pleading with citizens to grow more grain (eventually leading to a law enforcing the matter in 1748). The overworked, tobacco-worn soil along the Chesapeake was no longer as fertile, though, and fear and uncertainty made tidewater residents hesitant to journey into the western hinterland. If settlements were already established, however, the Marylanders along the shores might be encouraged to make the move. Upon hearing about the activity of the German migrants, Lord Baltimore, joined by Daniel Dulany, made a 1732 proclamation offering special terms and protection to families willing to stay in Maryland:

Any family that would arrive within the next three years and promise to settle in Maryland 'on any of the back Lands on the Northern or Western Boundarys of our said province' should receive two hundred acres of land of their own choosing, completely free for three years; from the fourth year on they should pay a rent of one cent per acre per year. Moreover, 'We doe Assure all such that they shall be as well Secured in their Liberty 
and property in Maryland as any of his Majesty's Subjects in any part of the British Plantations in America. ${ }^{24}$

Dulany and Lord Baltimore got the results they were hoping for as many German travelers accepted the offer and began to permanently settle in Western Maryland.

\section{The People and Their Towns}

The Germans in Western Maryland are consistently described as industrious and pious, as one author wrote: "The Christian motive is the most important element of their character." ${ }^{, 25}$ Once settled, these German immigrants took to cultivating the land and providing shelters for their families. They built "a school to educate their children in the Christian belief," and followed this with the construction of a new church. Once the edifice was complete, they sought a pastor to perform religious services and preach the word of God. What little time the settlers had beyond farming was "devoted to the church and the community.",26

Dulany had been attracted by the productive nature of the German settlers, and foreseeing their agricultural success, he planned a town in 1745 to serve as a market and service center for Maryland's western inhabitants. Dulany named the town after Lord Baltimore's son, Frederick. Germans living in Frederick spread word of the vibrant young city in their own language, drawing Pennsylvania emigrants from the north, as well as new colonists from the

\footnotetext{
$43-44$.

${ }^{25}$ Cunz, 60. For evidence of industry see Nead, 63-65.

${ }^{26}$ Cunz, 60.
}

${ }^{24}$ Quoted in ibid., 59; for a full reproduction of the proclamation see Nead, 
homeland arriving in Maryland's harbors. The town grew rapidly, faster than any other in Maryland. In 1748, Frederick County was created, and by 1750, with one thousand inhabitants, the county seat of Frederick had become the largest town in Maryland. ${ }^{27}$

From Frederick, settlement continued its westward push, delayed only by the French and Indian War. Prior to Frederick's founding, a young Germanborn immigrant named Jonathan Hager (1714-75) was buying land in the farthest reaches of Maryland, thirty miles west of the nearest habitations along the Monocacy in the hopes of founding a city. By 1762, Hager had accumulated about 2500 acres, planned a community, and began selling individual lots. Over the next ten years, 100 dwellings had been erected and the city of Elizabethtown (eventually renamed Hagerstown), developed into a center for business and social activities for the westernmost region of Maryland. ${ }^{28}$

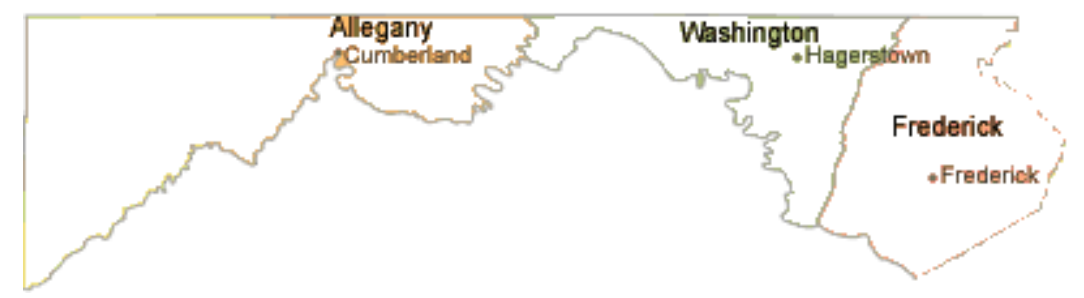

Figure 5: Western Maryland counties and county seats as of 1820. Maryland's current westernmost county, Garrett, was not founded until 1872.

Like Frederick, Hagerstown was home mostly to Germans. Lutheran and German Reformed congregations started their own parishes and built churches in
${ }^{27}$ Brugger, 69.
${ }^{28}$ Cunz, 81-85. 
1770 and 1774, respectively. ${ }^{29}$ Together, the German populations in Frederick, Hagerstown, and the outlying areas of Western Maryland helped turn the tobaccodependent economy into a more complex and balanced one "that included grains, milling, iron-making, and various small crafts and cottage industries." ${ }^{30}$ The region continued to grow throughout the Revolutionary years and into the nineteenthcentury, drawing new settlers to its thriving cities and fertile farmland. Though the English and Irish presence grew in proportion, the Germans of the region were the most significant contributors to the area's economic, social, cultural, and religious life. As we shall see, they also played an important role in the musical development of the state.

\footnotetext{
${ }^{29}$ Nead, 105-106.
}

${ }^{30}$ Brugger, 70. 


\section{Chapter 2: American Hymnody and Shape-Notes}

Since the music in the Brandstetter tunebook employs shape-notation and half of its tunes come from the American hymn tradition, an overview of the history of American hymnody and shape notation is essential. Shape-note hymnody is a direct descendent of the earliest European music produced on American shores, and the story of its development reveals the forces which molded the tradition while also shedding light on what it means for music to be American. The pressures of survival were foremost in the minds of early colonists, so musical literacy and education were secondary to more essential day-to-day tasks. Music was still required in religious services, however, and thus began the work of spreading music in the colonies.

Beginning in early eighteenth-century New England, a process of constant musical improvement can be observed. In hopes of bettering the musicality of settlers, new musical institutions were developed (such as singing-schools) and new materials (especially tunebooks) were created to accompany the increasing abilities of citizens. America's improving musical literacy eventually allowed native-born composers to write for local choirs, sprouting a new American musical style. In hopes of economic gains, tunebook compilers and printers tried to make their products more accessible to customers, leading to the creation of the shape-note system at the turn of the nineteenth century. Around this same time, the continuing desire for musical improvement in New England generated a powerful reform movement, pushing earlier New England music and shape-note notation south and westward toward untouched, less sophisticated rural and frontier regions. Shape-note hymnody continued its movement away from New England into the south and west. It is to this 
early nineteenth-century movement through the Mid-Atlantic region that the Brandstetter tunebook is connected.

\section{Early American Psalmody}

An important part of European culture brought to the New World was the Christian faith and its practices. Since life in the North American colonies was demanding, settlers had little time for leisure and tended to suppress intellectual and artistic pursuits. Psalm singing, however, was an integral part of religious services, and all members of a colonial community would have participated in it, especially since the Calvinist faith of the earliest settlers required congregants to worship together. Given the demands of daily life, few settlers were musically literate, and so they had to develop a tradition of well-known and simplified tunes that could be learned by rote. These tunes became the basis for early American sacred music.

The first printed European music on American shores came in the form of psalters, books that contained metrical psalms, translated, rhymed, and given a form of popular poetry that used "some of the same simple verse structures in which secular ballads that circulated in oral tradition were cast." ${ }^{\prime 1}$ Depending on the psalter, between thirty-nine and sixty-five melodies were given, to which each of the 150 psalm texts could be sung. ${ }^{2}$

The New England congregations of Salem and Plymouth voted to discontinue use of their psalters in 1667 and 1685, respectively, citing the difficulty of the tunes

\footnotetext{
${ }^{1}$ Richard Crawford, America's Musical Life (New York: W. W. Norton,
} 2001), 21.

${ }^{2}$ Harold Gleason and Warren Becker, Early American Music: Music in America from 1620 to 1920, 2d ed. (Bloomington: Frangipani Press, 1981), 3. 
and concerns over the accuracy of the psalm translations. In need of a psalter for religious services, the first full-length book printed in the colonies was published in 1640 and came to be known as the Bay Psalm Book (see fig. 6). This new psalter emphasized simplicity, and made regular use of only three poetic meters (common, short, and long). With so few meters, the congregation needed to know only a small number of tunes: five would cover the entire repertoire of psalm texts. This "shrinking stock of tunes shows that for the Reformed Protestants who settled New England, musical skill was not a high priority," but as they still needed to sing during services, maintaining a select number of simple tunes enabled all worshipers to easily participate. $^{3}$

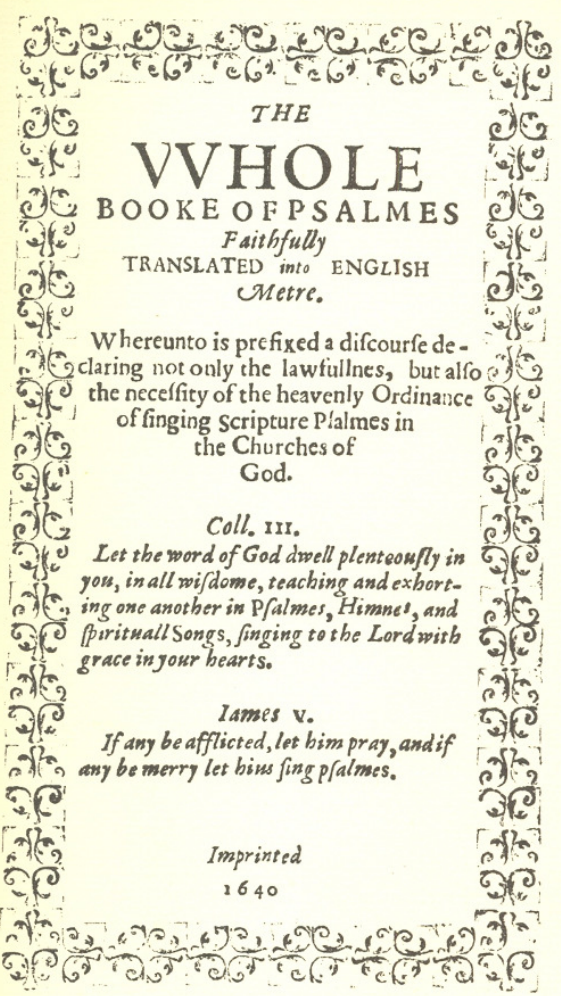

Figure 6: The Bay Psalm Book title page; reproduced from the University of Chicago Press facsimile.

\footnotetext{
${ }^{3}$ Crawford, 23-25.
} 
Following publication of the Bay Psalm Book, congregations began using a single leading singer who would choose a tune and read out the psalms line by line with the congregation singing the words back in alternation to the given melody. This practice became known as "lining-out," and it allowed congregants to sing without the aid of the printed text or tune. Over the next several decades, lining-out slowed the pace of worship greatly and served to limit the number of tunes to those already known by the congregation. Since very few worshipers could read music, the melodies had to be learned by rote, and over time the tunes began to differ between neighboring towns and even between parishioners within a given congregation. This was due in part to the emphasis placed on elaboration: churchgoers added their own personal flourishes to the slowly advancing melodies, creating a muddied, disorganized recitation. Despite the chaotic sound, many within the community developed a strong loyalty to the practice. ${ }^{4}$

By the 1720 s concerns were beginning to arise-mostly among clergymenthat lining-out was moving away from the traditional singing of Puritanism, which had always been guided by the written note. The clergy soon advocated a system governed by notation, calling it "Regular Singing," as opposed to the "Old Way" of lining-out. Their complaints were not simply about the sound of the Old Way. They also claimed that the words were lost in the disunity of the performances, and that the music was no longer serving its primary purpose of embellishing the psalm text. Supporters of Regular Singing believed that performance from written music would

\footnotetext{
${ }^{4}$ Ibid., 25.
} 
improve the sound of the congregation, as well as keep the holy words intelligible. ${ }^{5}$ Though Regular Singers were a minority, theirs were the loudest voices, and singing by the note would become standard practice. ${ }^{6}$ Before this was possible, however, musical literacy somehow needed to be spread through the New England colonies.

\section{Singing by the Note: Singing Schools and Tunebooks}

While transition from the Old Way to Regular Singing did not catch on immediately, once agreed upon, some type of system had to be organized for teaching music to the congregation. In response to this need came the singing-school. Singing schools were temporary institutions without a formal connection to the church. Instructors would meet with students for a few hours in the evenings, teaching them the rudiments of music and instructing them on how to read written notes. Singers rehearsed using solmization syllables that were later replaced with actual texts (a practice still heard in modern shape-note performances). Such schools lasted for several weeks, sometimes up to three months, and often culminated in a final public performance. Upon completion, those who attended (mostly young people) were ready to sing their tunes for public worship and in the home.

The desire for singing schools created a demand for singing-masters. Given music's low status in the colonies, it is no surprise that these instructors were not normally highly trained musicians, but rather Americans "whose sole credentials were likely to be enthusiasm and a little self-instruction."

\footnotetext{
${ }^{5}$ Ibid., 30-31.

${ }^{6}$ Ibid., 25-26.

${ }^{7}$ Cobb, 60.
} 
were members of a congregation who had the ability to teach the school, keeping whatever trade or work they did as their profession. But as singing-schools became more popular, one could make a career out of teaching in them. These new professional singing-masters were known for their itinerant lifestyle, and often advertised in local papers as they passed through towns, constantly searching for an interested audience. They were, in a sense, America's first professional musicians and they played a major role in spreading literacy, and eventually native music throughout the colonies. ${ }^{8}$

Naturally, these instructors required materials, but in early eighteenth-century America, the few tunes in the old Puritan psalters were the only printed music available. The demand for new material was met in 1721 by the Reverends John Tufts and Thomas Walter, who each produced their own books, complete with brief introductions on the rudiments of music and musical notation. These books also provided a set of tunes that were harmonized in three parts. ${ }^{9}$ Tufts's book is of particular interest because of the notation system he employed. A four-syllable "fasola" method of solmization was used in England where the major scale, ascending from tonic to tonic, is sung $f a-s o l-l a-f a-s o l-l a-m i-f a$ (for minor tunes, the singer would begin on the second la). Tufts, whose book was titled An Introduction to the Singing of Psalm-Tunes, in a plain \& easy Method, adopted this system by placing the capital letters F, S, L, and $\mathrm{M}(f a$, sol, la, $m i)$ on the staff in place of regular notes, and indicating durations with punctuation marks (see fig. 7). Though

\footnotetext{
${ }^{8}$ Crawford, 28.

${ }^{9}$ Gleason and Becker, 21-22. Tufts's first book was unharmonized, but later editions were set in three voices.
} 
this was not the first book to indicate syllables with letters, it was unique in using them to replace regular notation on the staff. ${ }^{10}$ This use of solmization syllables to aid sight-singing is certainly an early ancestor to shape-notation.

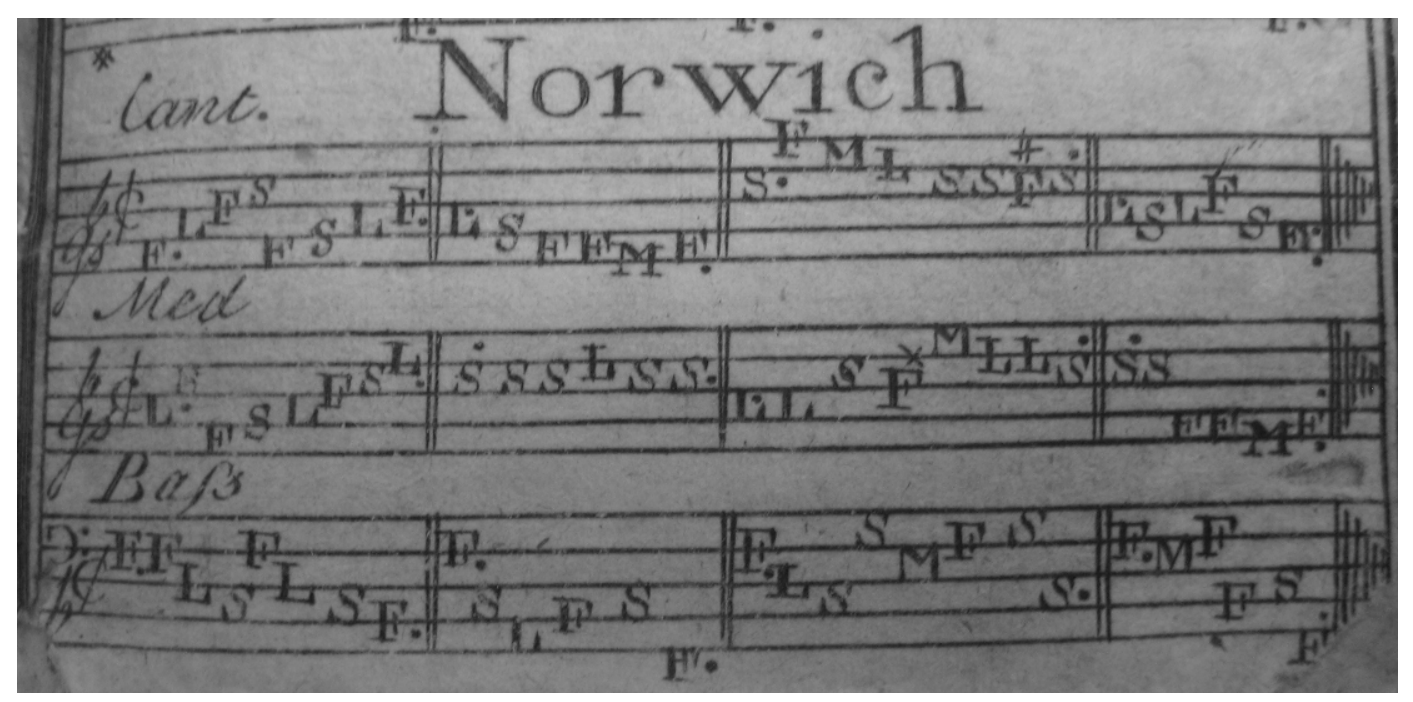

Figure 7 NORWICH from Tufts's An Introduction to the Singing of Psalm-Tunes, in a plain \& easy Method, 1738. Please note that tunes often got their names from towns, streets, geographic features, religious figures, or elsewhere, and are not necessarily connected to specific texts.

The early singing schools became quite popular for a number of reasons. They answered the call for Regular Singing and brought music literacy back to church services. Also, because the schools were not a formal part of the Church, they acted as social events for the young people who made up the majority of attendees. For many this was a welcome opportunity to spend time with the opposite sex, singing, socializing, and later walking home. ${ }^{11}$ Singing schools also left their participants with a new skill, which often led to the formation of local choirs for church service and

${ }^{10}$ The ninth edition Bay Psalm Book printed solmization letters below the staff, which was likely an imitation of the English publication by John Playford, $A$ Brief Introduction to the Skill of Musick (London, 1672). See Gleason and Becker, 11.

${ }^{11}$ Crawford, 33; Irving Lowens, Music and Musicians in Early America (New York: W. W. Norton, 1964), 282. 
public performance. By the 1760s, singing-schools were widespread in the Northern colonies, and choral singers began seeking new, elaborate, challenging, and modern music. $^{12}$

In 1761, James Lyon of New Jersey published the tunebook, Urania or A Choice Collection of Psalm-Tunes, Anthems, and Hymns. It supplied the market with 198 pages of music, far more than any other collection. The book was published in Philadelphia, the largest and most diverse city in the colonies at the time, and it contained the standard textless psalm tunes along with more elaborate melodies, anthems, set pieces, hymns, and fuging tunes. ${ }^{13}$ Urania was also the first tunebook to identify the works of native-born composers, including some of Lyon's own compositions. Significantly, the book responded to the desire for more complex music and also opened the door for other American composer/collectors to publish homegrown works. Urania, with its variety and broad appeal, was widely popular and demonstrated that there was a market for psalmody. ${ }^{14}$

${ }^{12}$ Crawford, 35.

${ }^{13}$ Crawford, 37; Gleason and Becker, 39. Fuging tunes were compositions inspired by earlier English works and became a favorite style among early American composers. The music normally begins in a chordal, homophonic setting followed by a contrapuntal section with staggered entrances, often using slight imitation (but certainly not to the degree of a classical "fugue"), and usually ends with all the parts coming together for a final homophonic statement.

${ }^{14}$ Crawford, 37. 


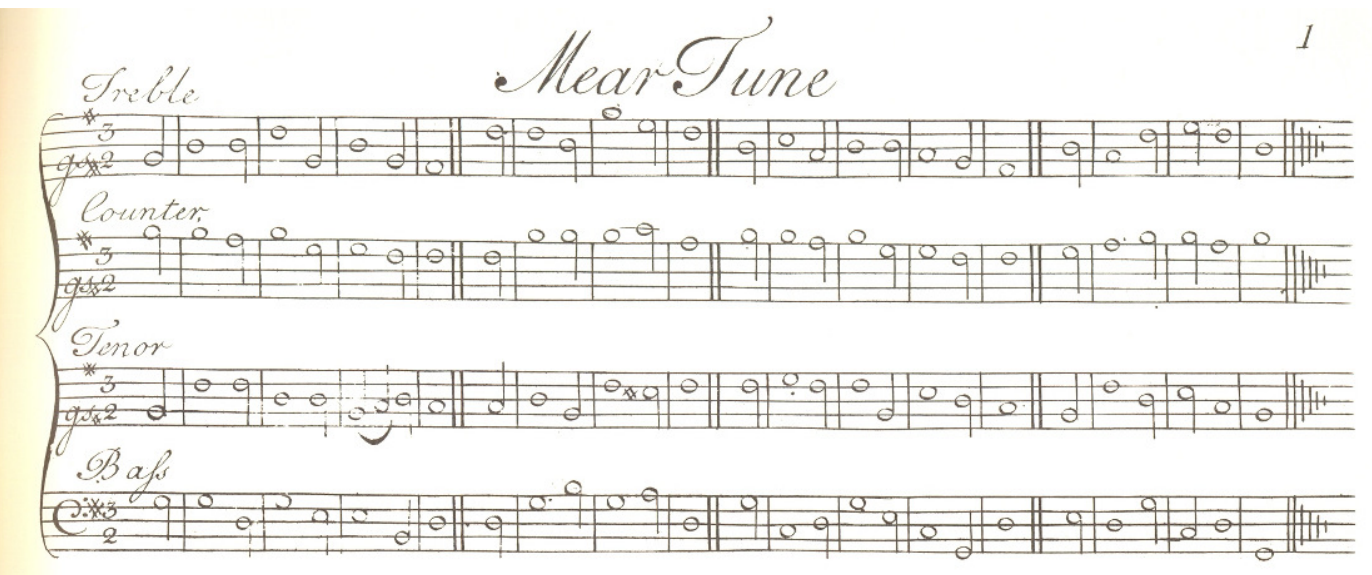

Figure 8 MEAR in Lyon's Urania, reproduced from the Da Capo Press facsimile.

The expanding pool of singers interested in new music created an opportunity for American composers in the colonies to be heard, and William Billings (17461800) of Boston was the first to make a significant and lasting statement. In 1770, he responded to the public's desire for elaborate and challenging work with The NewEngland Psalm-Singer: or, American Chorister, a collection of 127 original compositions by the author: "the first published compilation of entirely American music and the first American tunebook devoted wholly to the music of one composer." ${ }^{15}$ Billings's music included a variety of plain, homophonic tunes, as well as longer anthems and a number of fuging tunes, which are noteworthy for their high energy and melodic drive. The tunebook became popular and the composer released several other collections of music later in his lifetime, briefly gaining broad favor

15 Ibid, 38. 
within New England and other parts of the young country before falling into relative obscurity later in life. ${ }^{16}$

Along with Billings's popularity, his work is important for its musical style and philosophy. In his introduction to The New-England Psalm-Singer, Billings expressed the freedom by which he composed, saying, "I don't think myself confin'd to any Rules for Composition laid down by any that went before me."17 This attitude is reflected in the parallel voice leading and open sonorities characteristic of his music. As Billings was writing for an audience of enthusiastic choral singers, more attention is given to creating good melodies in each voice than in the resulting fourpart harmony. The music also tends to have a strong rhythmic drive and the main melody is always found in the tenor voice.

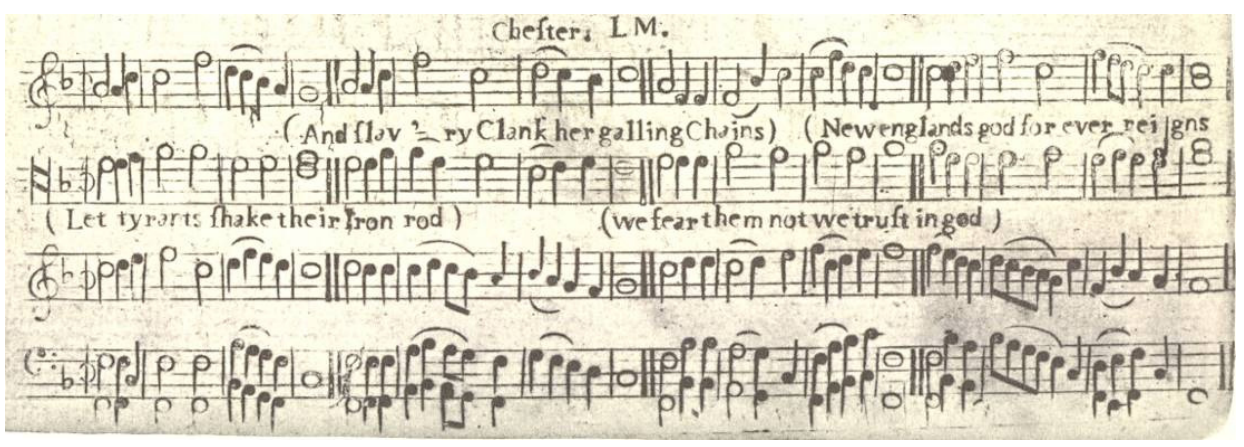

Figure 9 Manuscript copy of Billings's CHESTER. The main tune is in the tenor (third line down), and note stylistic traits such as the parallel fifths between the tenor and soprano in measure three, reproduced from Karl Kroeger, ed., The Complete Works of William Billings, Vol. 1, 320.

${ }^{16}$ Later works include The Singing Master's Assistant (1778), Music in Miniature (1779), The Psalm-Singer's Amusement (1781), The Suffolk Harmony (1786), and The Continental Harmony (1794) among other single-work publications. For more on Billings and his music see David P. McKay and Richard Crawford, William Billings of Boston: Eighteenth-Century Composer (Princeton: Princeton University Press, 1975) and William Billings, The Complete Works of William Billings, Karl Kroeger, ed., (Boston: American Musicological Society \& The Colonial Society of Massachusetts, 1981).

${ }^{17}$ Billings, The Complete Works of William Billings, Karl Kroeger, ed., vol. 1, 32-33. 
Billings's success inspired other compilers to try their hand at composition. Soon a number of New England psalmodists were writing raw, melodically-driven hymn and fuging tunes in the Billings style. ${ }^{18}$ With the increased number of tunebooks and singing-school graduates (and graduates-turned-masters), competition for book and school subscriptions rose, with each compiler and teacher seeking an advantage over the other. This state of affairs made it necessary to find better, more efficient ways to teach music using tunes that would satisfy the public taste.

\section{Shaped Notes}

With the expanding singing tradition and new desire for musical literacy, the challenge was clear: create a simpler process for learning to sing. ${ }^{19}$ If a professional instructor could teach a community to sing with ease and efficiency, he could more quickly earn his wage and move on to the next town, advertising his proficiency as a teacher along the way. If the printed tunebook could simplify musical literacy while offering satisfactory contents, it could gain an advantage in the bubbling marketplace.

At the turn of the century, two compilations "printed upon a new plan" were created to aid the learning singer. ${ }^{20}$ In 1798, William Little and William Smith were granted a patent for printing music using shaped-noteheads. ${ }^{21}$ The system used a combination of triangles, circles, squares, and diamonds to indicate the proper solmization syllables following the four-syllable method from England (see fig. 10). $51-56$.

${ }^{18}$ For an outline of New England Psalmodists see Gleason and Becker, 38-40,

${ }^{19}$ Cobb, 66.

${ }^{20}$ Andrew Law's The Art of Singing (1803), quoted in Gleason and Becker, 49.

${ }^{21}$ Crawford, 130. 
Durations were still indicated in the same manner as normal notated music, only the noteheads had different shapes. Though patented to Little and Smith, this system was designed by fellow Philadelphian John Connelly, who showed it to the publishers in hopes that it could be used to benefit the public in helping them learn to sing. ${ }^{22}$ In 1802, New England singing-school master and tunebook compiler Andrew Law (1748-1821) patented a similar system that reversed the syllables connected with the triangle and square. Significantly, Law's method removed the staff and instead raised and lowered the notes relative to one and other. This difference may be the reason for the success of Little and Smith's system over Law's.

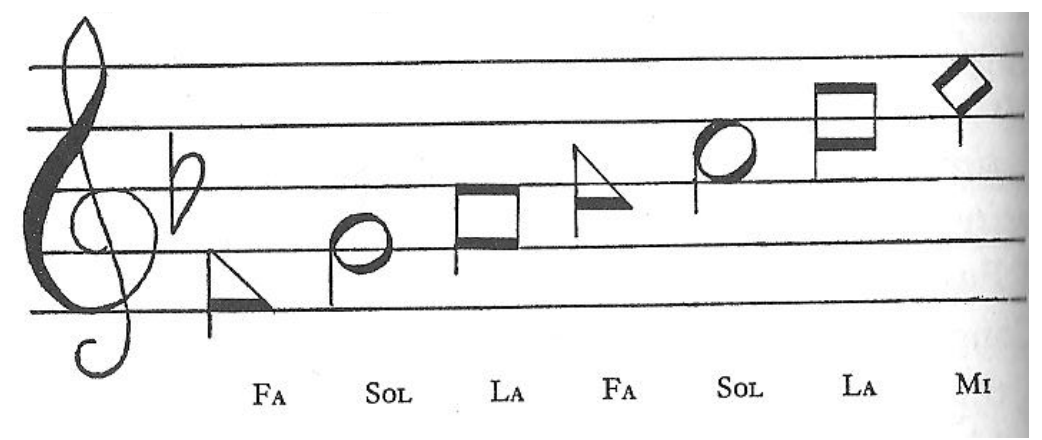

Figure 10 Little and Smith's four-shape notational system, reproduced from Jackson, White Spirituals of the Southern Uplands, 14.

The first shape-note tunebook was published in 1801 by Little and Smith of Philadelphia. Called The Easy Instructor, the book was a compilation of anthems, hymns, and fuging tunes already popular in New England (see fig. 11). The book became a success only after another printing in 1805 in the city of Albany. The Albany printing began a pattern of popular shape-note tunebooks being published in non-major cities, and indeed the shape-note tradition—despite being based on the

${ }^{22}$ Miller, Traveling Home, 5. 
psalmody of William Billings and his fellow New England composers-never found a publisher in New England. This fact suggests that there were forces present in the early nineteenth century keeping shape-notes out of the more developed, urbanized areas; people who regarded shape-notes not as an innovation, but as a crutch for those of lesser attainment. ${ }^{23}$

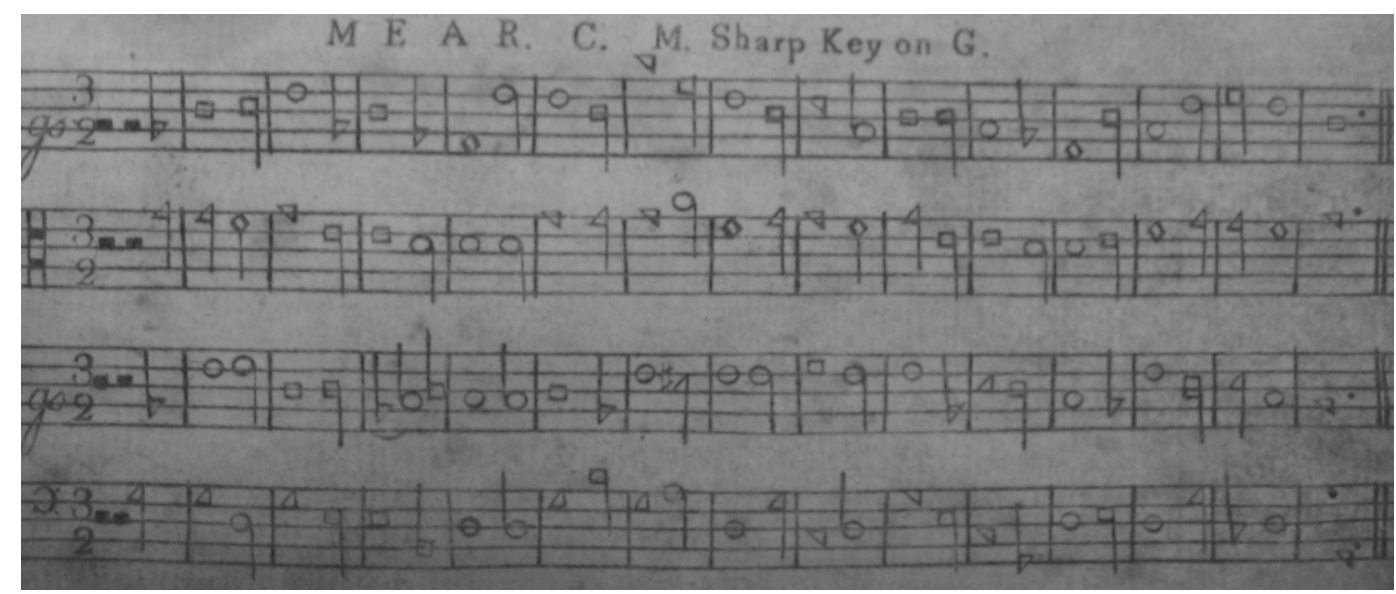

Figure 11 MEAR from Little and Smith's The Easy Instructor, 1802.

\section{Musical Reform}

On July 21, 1836, an advertisement was printed in the Cincinnati Journal and Western Luminary: The publishers announce a new edition of Mason's Sacred Harp, "printed in round notes; the patent note (shape-note) system being a miserable device, a mere shift to clothe ignorance and laziness with the look of science."24 The Mason name on the title of this Ohio tunebook comes from the famous family of American music educators, composers, and tunebook compilers best represented by Lowell Mason and his brother Timothy. The Masons were leading figures in a campaign to "improve" the music of America, reforming the "incorrect" habits of American

${ }^{23}$ Crawford, 131.

${ }^{24}$ Quoted in Bealle, 46. 
composers and singers in hopes of improving the moral quality of the American public through "better" music.

Despite beginning his career as an advocate for American music and later publishing his own shape-note system, Andrew Law was among the reformers who turned back to European compositions during the final decade of the eighteenth century. Law found faults in the music of Billings and the other Yankee tunesmiths and blamed his findings partially on the poor singing of the early New England choirs. He complained of the choirs' inability to properly tune and the "harshness of our singing," which led American composers to write lifeless tunes centered on perfect harmonies (fifths and octaves) that lacked variety and motion. By the turn of the century, Law supported a return to the rules that governed European composition. $^{25}$

Law was not alone in his call for reform. Since singing-schools were administered outside of church oversight, trained choirs and singing parishioners had taken control of sacred music away from the clergy. Clergy members and other community leaders, unhappy with the new Yankee tunes, began a push for "ancient music"; that is, European tunes of earlier decades and centuries (or new tunes in the same manner) which had a simpler, often homophonic style based on primary chord harmony. ${ }^{26}$ In the tunebook market, American compositions began to make up a smaller and smaller portion of the total content, and Americans hoping to have their tunes published were obligated to compose in the "correct" European manner.

${ }^{25}$ Richard Crawford, Andrew Law, American Psalmodist (Evanston, IL: Northwestern University Press, 1968), 105-106.

${ }^{26}$ Ibid., 132. 
The most important issue reformers had with the American compositions was that, while they still offered praise to God, their "crudities" and "faults" made for "unscientific" music. Incorrect music and poor singing, then, did not offer edification to the congregation. Singing-school masters, brought up with and later teaching the psalmody of Billings and his contemporaries were driven away from New England towns, the birthplace of their institutions, and labeled as "unqualified tricksters who were cheating honest Americans out of a civilizing musical education., ${ }^{, 27}$ In the same way that the Regular Singing movement removed lining-out from common practice at the beginning of the eighteenth-century, this second musical reform sought to do away with the singing-school and shape-note traditions. Hoping to maintain their livelihood (and maybe with a true belief in the music they fostered), the singingmasters moved south and west to the rural and frontier communities where the influence of the "Better Music boys" had not taken affect, including the wilds of Western Maryland. ${ }^{28}$

\section{The Tunebooks of John Wyeth}

As the singing-schools moved into new territory south and west of New England, tunebook printing accompanied the migration. A tunebook's success depended on its musical contents meeting the tastes of potential buyers. The early nineteenth-century tunebooks of New England reflected the reform movement in showing a greater influence of European-style hymnody, but the same books did not

\section{${ }^{27}$ Miller, 7.}

${ }^{28}$ George Pullen Jackson refers to the reformers, particularly those led by Lowell Mason, as "Better Music boys" and "Better Music boosters" in his White Spirituals of the Southern Uplands (Chapel Hill: The University of North Carolina Press, 1933). 
necessarily appeal to singers outside of this territory. New tunebooks, then, needed to be printed, and the most successful ones — those of John Wyeth especially—fit the character of their audiences and influenced later collections.

John Wyeth (1770-1858) was born in Cambridge, Massachusetts and though much of his biography is unknown, it is suspected that he attended a singing-school in the 1780s. ${ }^{29}$ Throughout his life, Wyeth appears to have shown little interest in music, but his job as a printer in Harrisburg, Pennsylvania, kept him abreast of the developments in tunebook publication and its expanding popularity. Wyeth defended his qualifications as a compiler in his momentous Wyeth's Repository of Sacred Music (1810), bragging of his years of experience with "the charms of church music," his "extensive acquaintance with the taste of teachers of the first eminence in the United States," and his "possession of some thousand pages of selected music to cull from." ${ }^{30}$ The Repository also demonstrates Wyeth's desire to print and sell a popular tunebook rather than to make any type of musical statement. ${ }^{31}$ His appeal to the marketplace is shown in part by his use of the Little and Smith shape-notation, but also by the fact that there are no new tunes in the Repository (see fig. 12). ${ }^{32}$ The contents point to popular northern tunebooks of the preceding decades, especially

${ }^{29}$ Steel, "John Wyeth and the Development of Southern Folk Hymnody," 358.

${ }^{30}$ John Wyeth, "Preface" to Wyeth's Repository of Sacred Music, facsimile of the 5th ed., Irving Lowens, ed., (New York: Da Capo Press, 1974): 3.

${ }^{31}$ Steel, 359

${ }^{32}$ Irving Lowens, "John Wyeth's 'Repository of Sacred Music, Part Second': A Northern Precursor of Southern Folk Hymnody," Journal of the American Musicological Society 5 (summer 1952), 116. 
Little and Smith's The Easy Instructor, where a number of unique errors and misattributions are repeated in Wyeth's collection. ${ }^{33}$

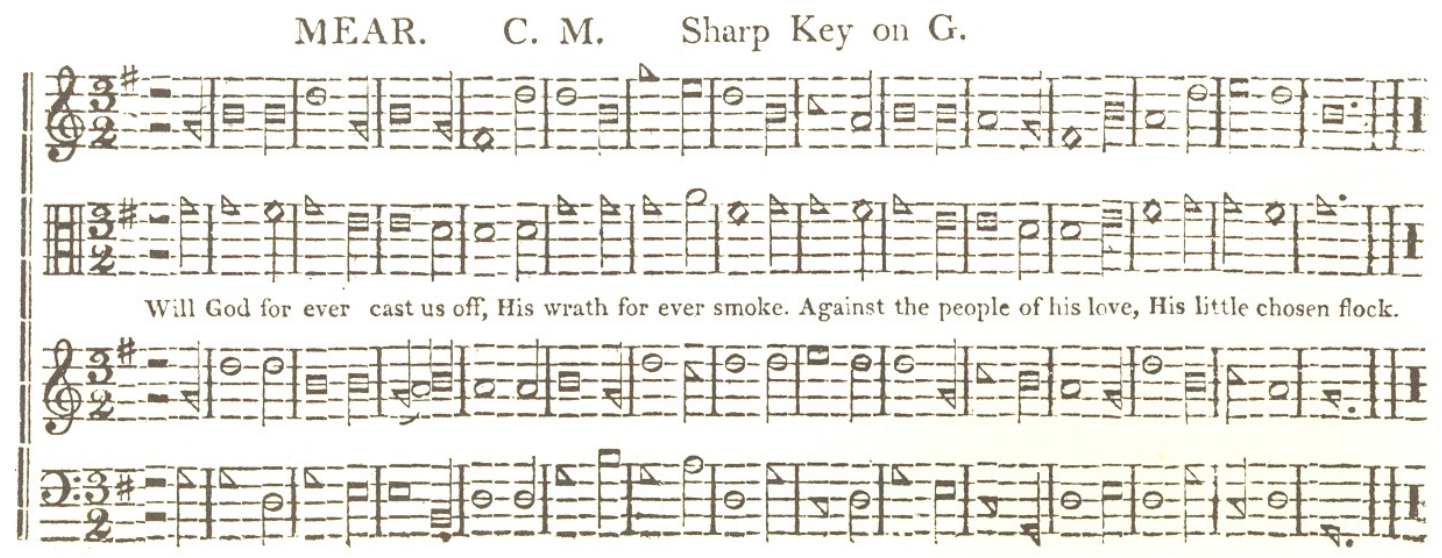

Figure 12 MEAR in Wyeth's Repository of Sacred Music, reproduced from the Da Capo Press facsimile reprint.

Though the tunes of the Repository come from a psalmody that had lost its popularity in the northern colonies, the book was met with great success in Pennsylvania, going through four editions in its first decade alone. ${ }^{34}$ This is a credit to Wyeth's grasp of the rural Pennsylvanian tastes that had not yet been tainted by the ideas of the northern reformers. The German population of the region showed a particular preference for shape-notes, as well as the raw style of the early New England tunes of Billings and his contemporaries. ${ }^{35}$

In 1813, Wyeth published a second tunebook, Wyeth's Repository of Sacred Music, Part Second, which looked like the first Repository, but was completely

${ }^{33}$ Irving Lowens ed., "Introduction" to Wyeth's Repository of Sacred Music, facsimile of the 5th ed., (New York: Da Capo Press, 1974), viii; Steel, 361.

${ }^{34}$ Steel, 366.

${ }^{35}$ Ibid., 360 . 
different in terms of content. ${ }^{36}$ At the turn of the nineteenth century, the emotionally charged religious revivals known as "camp meetings" were spreading, and these meetings produced a new type of hymn that used folksong and folk-like melodies in combination with religious texts. ${ }^{37}$ The new folk hymns were easy to learn and memorize, and served the needs of the revival singers. Wyeth's Part Second included a number of folk hymns, harmonized so that each singer's part retained melodic interest.

With his Repository available to the evangelical mainstream, Wyeth's Part Second offered the "radical evangelicals" a tunebook that served their needs as well. Because Wyeth was positioned in Harrisburg, near the edge of frontier America, it was his books that supplied settlers with New England psalmody (still new to Americans in the southern half of the country) and revival music (which was popular along the newly settled edges of the south and west). ${ }^{38}$ From Wyeth's publications, American hymnody descended into the Mid-Atlantic and Southern states in shapenote form where it would become ingrained, developed, and maintained over the next two centuries.

\section{Into the Mid-Atlantic and the South: The Work of Ananias Davisson}

The next step in the story of shape-note hymnody as told by Jackson and his followers normally leads to Harrisonburg, Virginia, and the publications of Ananias

\footnotetext{
${ }^{36}$ Lowens, "Northern Precursor," 117.

${ }^{37}$ Michael Broyles, "Immigrant, Folk, and Regional Musics in the Nineteenth Century," The Cambridge History of American Music, ed. David Nicholls (New York: Cambridge University Press, 1998), 152-54.

${ }^{38}$ Steel, 367.
} 
Davisson, notably the Kentucky Harmony (1816) and the Supplement to the Kentucky Harmony (1820). Davisson's tunebooks are portrayed as the collections that brought the works of Yankee tunesmiths and spiritual folk hymns into the southern portion of the country. ${ }^{39}$ Though the evidence supporting Davisson's influence on later southern collections (which will be explored below) is undeniable, the details concerning the movement from Pennsylvania into the Shenandoah Valley remain clouded, leaving a large gap between Wyeth and Davisson.

Ananias Davisson (1780-1857) was a printer in Harrisonburg, Virginia who likely had experience as a singing-master within the first two decades of the nineteenth century. ${ }^{40}$ His Kentucky Harmony mixed Northern hymns and fuging tunes with revivalist folk hymns. Davisson printed a number of new tunes in familiar styles, claiming authorship for some, but the most significant source of music for his tunebook appears to have been Wyeth's two Repositories, which "account for no less than 98 of the 143 tunes found in Davisson's first" edition of the Kentucky Harmony (see fig. 13). ${ }^{41}$ The Kentucky Harmony went through five printings in a decade, and the Supplement received at least three from 1820-1825. The sheer number of editions is indicative of a successful tunebook. Taking into consideration that he sold the books in the more spacious rural and frontier states of Virginia, Tennessee, the

${ }^{39}$ Jackson, 26-93; Steel, 370.

${ }^{40}$ Harley, 8-9.

${ }^{41}$ Irving Lowens, Introduction to the Facsimile Edition of Kentucky Harmony (Minneapolis: Augsburg Publishing House, 1976), 9. 
Carolinas, Georgia, Kentucky, and Ohio, Davisson's accomplishment is all the more impressive. $^{42}$

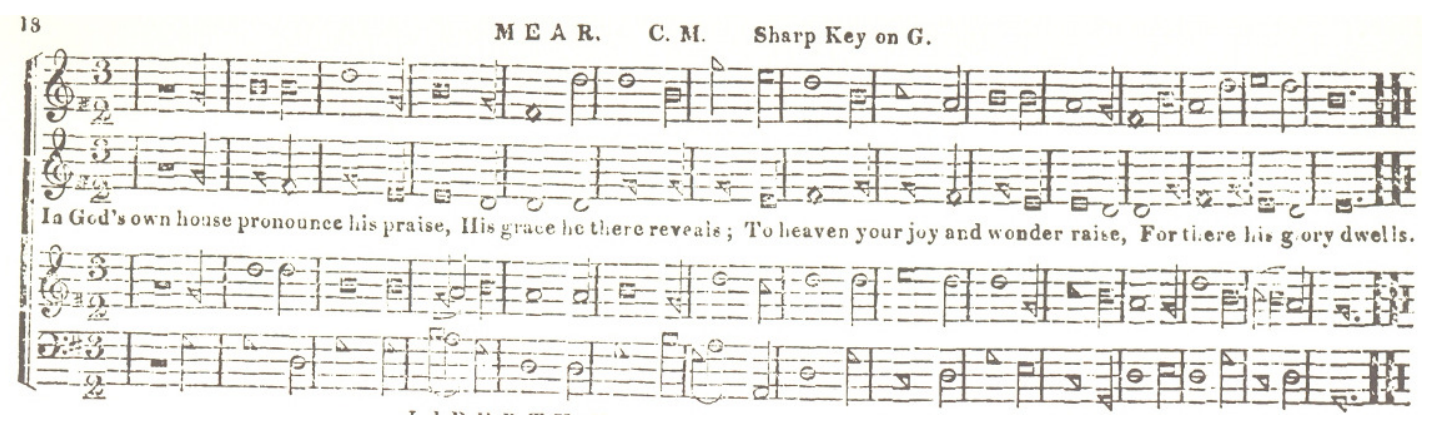

Figure 13 Davisson's setting of MEAR in the Kentucky Harmony. Note the new text, as well as the changes made to the bass and alto parts to add melodic interest, reproduced from the Augsburg facsimile.

Davisson's influence on the shape-note tradition has been traced through analysis of later Mid-Atlantic and Southern tunebooks. The books of the Shenandoah Valley all show a relation to Davisson, either in borrowing tunes, rudiments, or working with Davisson as a printer or in response to him as a competitor. ${ }^{43}$ Looking beyond the Valley of Virginia, the Missouri Harmony (1820, compiled in Missouri and printed in Cincinnati) went through multiple editions into 1850 and was recently revised in 2005; its contents are nearly the same as those in the Kentucky Harmony. ${ }^{44}$ The Columbian Harmony from West Tennessee (1825) went through multiple editions during the 1830s and 1840s. The compiler, William Moore, "leaned heavily on Ananias Davisson" for his introduction and rudiments, and the tunes themselves

${ }^{42}$ Eskew, 23.

${ }^{43}$ These books include The Virginia Sacred Minstrel, The Virginia Sacred Musical Repository, Choral-Music, A Compilation of Genuine Church Music, and the Virginia Harmony, among others. See Eskew, chapters 3-5.

${ }^{44}$ Jackson, 39-40. 
can largely be traced back to Davisson's work. ${ }^{45}$ The introduction to William Caldwell's Union Harmony (1837), which served as a model for later East Tennessee tunebooks, borrowed its material "largely from Davisson's works, and more than sixty percent of the tunes and texts were from Davisson's books." ${ }^{46}$ Over sixty tunes in the Knoxville Harmony (1838) were from either the Kentucky Harmony or the Supplement. Finally, The Harp of Columbia (1848) has fifty-five tunes that can be traced back to Davisson, and the related New Harp of Columbia (1867) shows a connection to Davisson as well. ${ }^{47}$

While the importance of Davisson's publications is clear from the number of books that borrow his material, the Kentucky Harmony and the Supplement's most significant connection is to the widely popular shape-note tunebooks called The Southern Harmony (1835, compiled in South Carolina) and The Sacred Harp (1844, compiled in Georgia). These two books, in a sense, are the culmination of the fourshape shape-note tradition as they are two of the largest and most financially successful collections (both still finding regular use today). The Southern Harmony's popularity is reflected in its selling 600,000 copies during the nineteenth century. ${ }^{48}$ Its compiler, William Walker (1809-1875), made a distinct attempt to include a broad selection of music, texts, and composers—new and old—-that led in part to the book's great success. Concerning The Southern Harmony's contents, George Pullen Jackson

${ }^{45}$ Ibid, 44-46.

${ }^{46}$ Marion J. Hatchet, "Early East Tennessee Shape-Note Tunebooks," in The Hymn 46, no. 3 (July 1995): 29-30.

${ }^{47}$ Ibid., 30-37.

${ }^{48}$ Glenn C. Wilcox, Introduction to The Southern Harmony, fifth printing of the 1854 edition (Lexington: University Press of Kentucky, 1993), iii. 
writes: "the influence of other southern song books is not felt in the way of song borrowings. Ananias Davisson's Kentucky Harmony is an exception." ${ }^{49}$ Even with Walker's fresh and varied repertoire, Davisson's presence can still be detected.

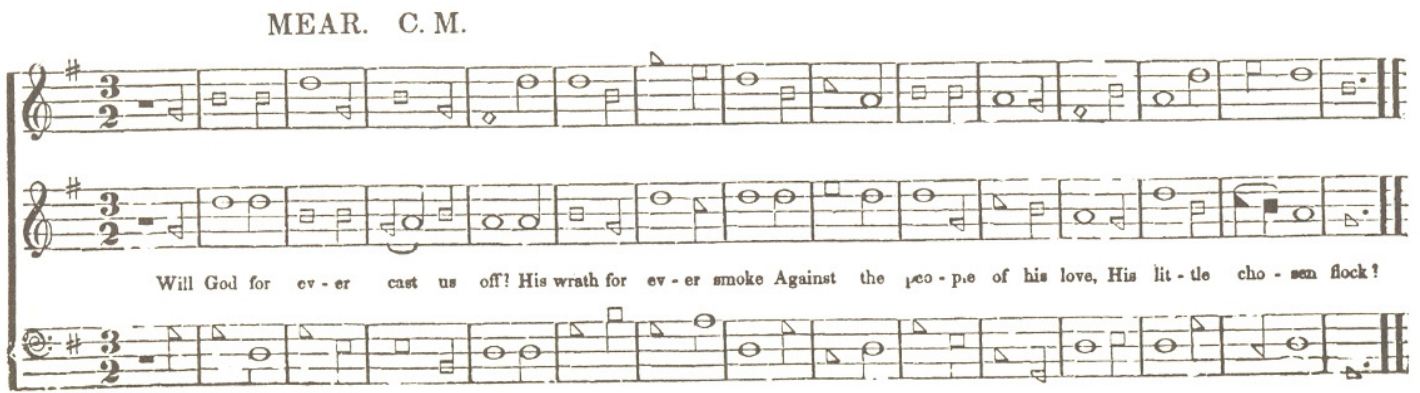

Figure 14 MEAR from William Walker's Southern Harmony. Here, Walker has retained the original bass line but used the tenor's final cadential gesture from Davisson's arrangement, reproduced from the Southern Harmony, 1987 reissue of the 1854 edition.

The Sacred Harp, originally compiled by B. F. White and E. J. King in Georgia, was the chief competitor to Walker's Southern Harmony. ${ }^{50}$ White had actually worked with Walker on the compilation of The Southern Harmony, but, for unknown reasons, was not given credit. Much of the contents, then, of Walker's book are present in The Sacred Harp. Though Davisson has only one authored tune within the collection, a number of tunes that were first printed below the Mason-Dixon Line by Davisson appear in The Sacred Harp's pages.

White and King's tunebook may be the most important of all four-shape publications in that it survived a series of musical reforms. Despite near-extinction, The Sacred Harp was kept alive in a few rural Southern communities and is now a widespread musical phenomenon, representing popular conceptions of the shape-note

${ }^{49}$ Jackson, 62.

${ }^{50}$ George Pullen Jackson, Introduction to The Sacred Harp (facsimile of the third edition) (Nashville: Broadman Press, 1968), xii. 
tradition all around the United States. The Southern Harmony also receives modern use, but to a far lesser extent, serving as the tunebook for the annual Big Singing in Benton, Kentucky, which regularly attracts hundreds of singers from around the country.

Both books are stalwarts of the shape-note singing tradition and are descendants of Davisson's collections, so his role in the dissemination of the music is key. The question remains, however, of how Davisson first came into contact with this musical tradition. Since he was the first in his area to bring the music into print, he had no local predecessors; and even in 1820, four years after Davisson's first publication, Wyeth was not selling either his Repository or Part Second in Virginia. ${ }^{51}$ The theory that Davisson learned of shape-notes from itinerant singing-master Lucius Chapin has been suggested, but there is little hard evidence to support it. ${ }^{52}$

A key to answering this puzzling question may be found within the community that produced the Brandstetter tunebook. While it is certain that there was movement between Pennsylvania and the Valley of Virginia, particularly by migrating Germans, the details remain sketchy. The Germans in Maryland, however, provide a pathway for the shape-note tradition to spread from the communities around Harrisburg into the southern half of the country.

${ }^{51}$ John Wyeth, title pages to both Wyeth's Repository of Sacred Music and Wyeth's Repository of Sacred Music, Part Second.

52 Hamm, 97. 


\section{Chapter 3: German-Immigrant Musical Culture}

The first wave of German immigration to America began in the final decades of the seventeenth century and continued well into the nineteenth century. After landing in the New World, these immigrants tended to form insular communities, the great majority in the frontier regions of Pennsylvania. ${ }^{1}$ The focus of this chapter will be the musical culture of the Germans of Pennsylvania, commonly known as the Pennsylvania Dutch. Despite the cultural homogeneity of the German communities, rifts developed among the immigrants. These divides fell partially along religious lines, but differences over maintaining a strictly German heritage versus adapting to the new Anglo-American environment were even more significant. These disagreements are reflected in the music produced in the late eighteenth and early nineteenth century, as the influence of American hymnody becomes ever more present.

\section{Religion's Role}

As explained by Daniel Grimminger, the Germans who landed in American harbors represented a diverse array of Christian denominations, differing in theology and musical practice. Nonetheless, these immigrants can be organized into three categories. The Sektenleute included denominations that emphasized a theology of separation, removing themselves from the larger society (within this group are the Amish and Mennonite orders). Putting less emphasis on separation, but living communally and at least somewhat isolated from mainstream society, were the

\footnotetext{
${ }^{1}$ Broyles, 145-46.
} 
Brüdergemeinen, more widely known as the Moravians. Finally, the non-separatist Kirchenleute - represented by the Lutheran and German Reformed churchesworked to become a part of, and serve, the larger communities around them. Of course, for the social and political reasons discussed above, these immigrants often lived among other Germans, away from Anglo-American residents, but not because their religion prescribed separation. ${ }^{2}$

While these theological divisions are somewhat flexible, each group developed a unique sacred musical tradition in the New World. For two main reasons the Kirchenleute will be the focus of this study. First, Lutheran and Reformed believers formed the bulk of German settlers in Western Maryland. Second, since the Kirchenleute were more willing to interact with Anglo-American society, they participated in a "process of cultural compromise," which resulted in American music becoming a part of Lutheran and Reformed practices. ${ }^{3}$ Tracing the musical history of the Kirchenleute in America will place them chronologically and geographically at the pivotal point where shape-note music began crossing the Mason-Dixon Line into the southern half of the United States.

\section{German-American Culture and Music}

Within the German communities settling in America, there was a tension between two groups: those wanting to retain their Germanic culture versus others wishing to assimilate their new Anglo-American surroundings. Interestingly, both sides turned to art and music. Because the Kirchenleute maintained a written sacred 17.

${ }^{2}$ The three-part division of the religious groups comes from Grimminger, 13-

${ }^{3}$ Grimminger, 1 . 
music tradition, surviving sources demonstrate how "Germanizers" and "Americanizers" tried to use music to achieve their respective goals. ${ }^{4}$ Through these sources, a transition from traditional German sacred music to hymnody dominated by Anglo-American traits can be observed during the early decades of the nineteenth century. The characteristics of the sources showing how Germans adapted AngloAmerican practices are most important because they connect the manuscript sources from Western Maryland to the musical materials in Pennsylvania, reflecting both cultural retention and acculturation.

\section{$\underline{\text { Cultural Retention }}$}

The chorale was the most essential part of German musical culture and made up the majority of immigrant repertoire. Chorale and song books were among the few textual items accompanying immigrating Germans, and the significant number of text-only books illustrates just how ingrained the chorale tradition was for early settlers as certain tunes had been memorized and did not require notation. ${ }^{5}$ The strong presence of the chorale tradition made retention easy; and if new books were needed, they could simply be shipped from Germany. Economic strains and war in the latter decades of the eighteenth and early nineteenth centuries often interrupted this system, however, necessitating the creation of musical materials by Germans living in America. ${ }^{6}$

\footnotetext{
4 The terms "Germanizer" and "Americanizer" are used by Grimminger to define the two groups. See Grimminger, 8.

${ }^{5}$ Cunz, 60; Grimminger, 69-72.

${ }^{6}$ Grimminger, 81-83.
} 
For the Germans wishing to maintain the musical culture of their homeland, the new publications needed to resemble what their community had imported earlier, and they were often successful in this task. ${ }^{7}$ An analysis of these "retentive tunebooks" reveals a number of uniquely Germanic elements. First, German was the sole language used throughout such books, from title pages and introductions, to music texts and indexes. The introductions of retentive books tended to put forward the goals of the book as seen by its compiler(s). This stands in sharp contrast to the "rudiments of music" found in Anglo-American publications. Because most Germans crossing the Atlantic in the late eighteenth and early nineteenth centuries knew how to read music, an explanation of musical notation was usually unnecessary. The texts of retentive tunebooks show a concern for traditional Lutheran and Reformed values, especially the gift of God's grace, justification by faith alone, the sacraments, and such key theological ideas as the Trinity and Christ's two natures.

The music found in these books also reflects the German heritage. The musical contents are derived from the European repertoire, with chorales serving as the predominant genre. The majority of the books were printed from engravings or punched plates, instead of the moveable type common to American music printers. When moveable type was used, the typeface was imported from Germany. Of course, round note-heads were used without exception, as shape-notes were purely American in origin. The voicing and style of the music was also reminiscent of the German tradition. Chorales were often printed on two staves and in two-parts with an unrealized figured bass. In some cases, three- and four-voice settings were used, but

\footnotetext{
${ }^{7}$ Westermeyer, “The Evolution,” 155.
} 
they maintained the musical characteristics of the chorale style. The music tended to move homophonically in rather constant, square rhythms, and melodies were conjunct, employing small intervals—mostly seconds and thirds (see fig. 15). ${ }^{8}$

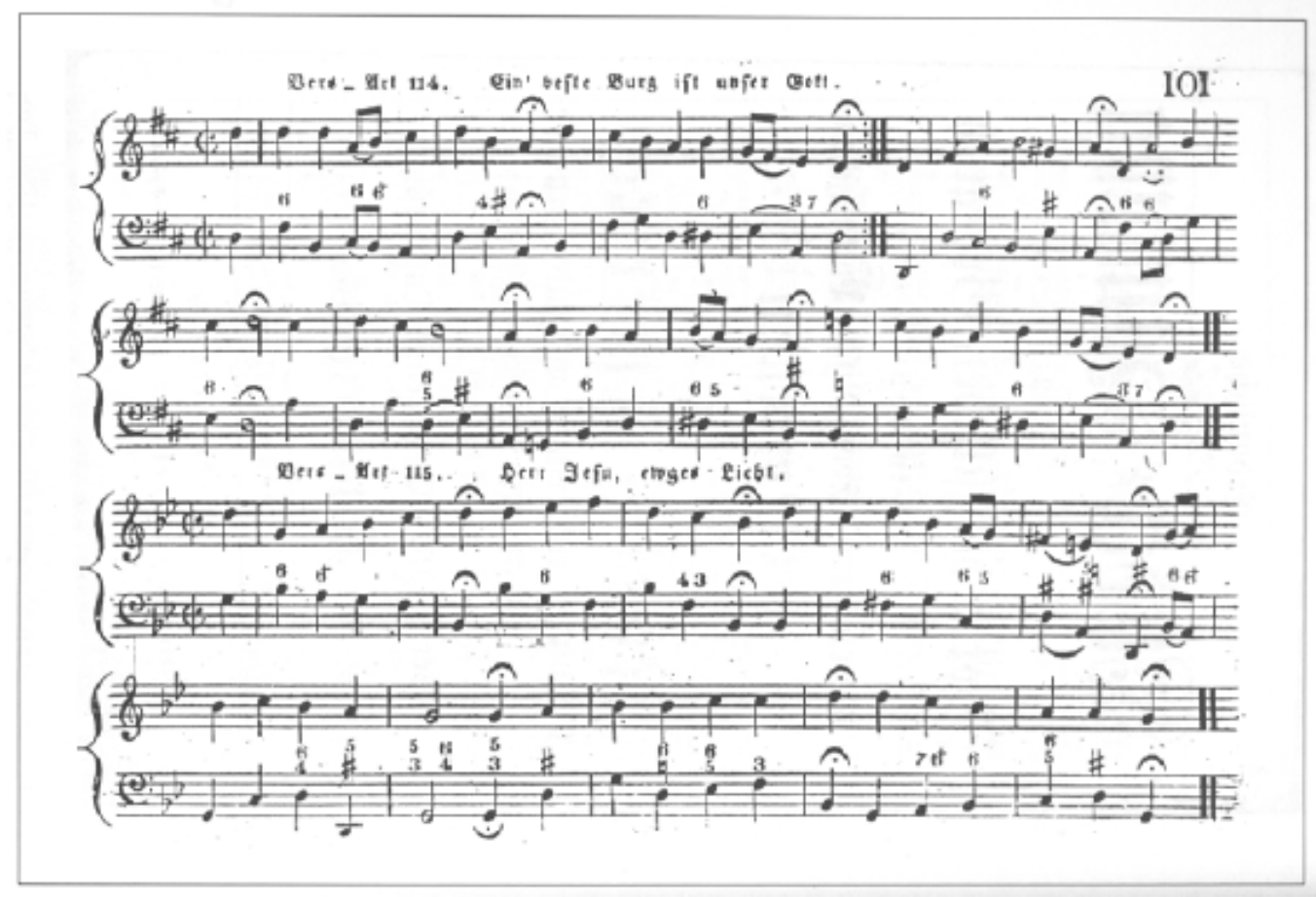

Figure 15 A page from Heinrich Helmuth's retentive chorale book, Choral-Buch fur die Erbauliche Lieder-Sammlung, 1813, reproduced from Grimminger, 106.

Most extant tunebooks from this retention stage are most numerous between 1786 and 1833, though their popularity appears to have declined among some Germans during the 1820s. After 1841, the number of new publications of this kind falls off considerably. ${ }^{9}$ This decline could be due to changing tastes and the appeal of hymnody from outside the German tradition. There may also be a parallel to the pilgrims' story: as a younger, native-born generation was exposed less to High-

\footnotetext{
${ }^{8}$ Grimminger, $83-86$.

${ }^{9}$ Ibid., 87.
} 
German culture-particularly in rural areas - the appearance of strange figured-bass figures with no way to realize them may have felt inaccessible to untrained, nonprofessional musicians. As in New England, a form of music accessible to amateur singers was needed, as were the institutions to teach this new repertoire.

\section{$\underline{\text { Acculturation }}$}

In the early nineteenth century, there was an increasing English-speaking element in German communities, and an increasing interest in Anglo-American traditions. The greater preponderance of the English language can be attributed to the desires of a new generation who needed to do business with their Anglo neighbors. ${ }^{10}$ But the English language did not necessarily have to become a part of religiousmusical practice. Also, the singing school institution had found a place within the German communities, demonstrating that there was more to the American influence than simply the need to deal with Anglos on a day-to-day basis.

Lutheran and Reformed parochial schools in North America were holding their own singing schools, based on the American model, by the late eighteenth century. There is also evidence of singing school activity in a less sectarian Mennonite denomination of Pennsylvania by $1780 .{ }^{11}$ Like the institution born in New England to teach "Regular Singing," these schools were meant to give students grounding in musical notation and the church music repertoire. (They also offered courting opportunities to young Germans, just as they had for contemporary English

\footnotetext{
${ }^{10}$ Grimminger, 48-49.

${ }^{11}$ Ibid., 63; Suzanne Gross and Wesley Beg, "Singing It 'Our Way': Pennsylvania-German Mennonite Notenbüchlein (1780-1835)," in American Music 19 (summer 2001), 190-209.
} 
students. ${ }^{12}$ ) While the schools were used by Germanizers to pass on their ethnic identity to a younger generation, the outside influence of American culture was reflected in the materials used and produced by the singing-masters. This crosspollination can be seen most clearly by contrasting the elements of the "retentive tunebook" and the new "adaptive tunebook.",13

Whereas the German language dominated retentive tunebooks, adaptive tunebooks tended to be bilingual. English tune names sometimes appear at the head of pieces, and song texts can be in both German and English. At times, a song will have verses in English as well as verses in German, though they are usually not direct translations of one to the other. Even when German serves as the main language, the texts may reveal Anglo-American connections. An example is the introduction to Joseph Doll's 1810 tunebook, Leichte Unterricht. This title-_"The Easy Instructor”is borrowed from the first shape-note tunebook by Little and Smith, which had gained popularity just years before Doll's publication (see fig. 16). Not only is the title shared, but the introduction is nearly a direct translation of the one found in Little and Smith's The Easy Instructor. ${ }^{14}$

${ }^{12}$ Grimminger, 62-63.

13 Ibid., 143-147.

${ }^{14}$ Referenced in Grimminger, 148, from Irving Lowens and Allen P. Britton, “"The Easy Instructor' (1798-1831): A History and Bibliography of the First Shape Note Tune Book," Journal of Research in Music Education 1, no. 1 (spring 1953), $30-55$. 


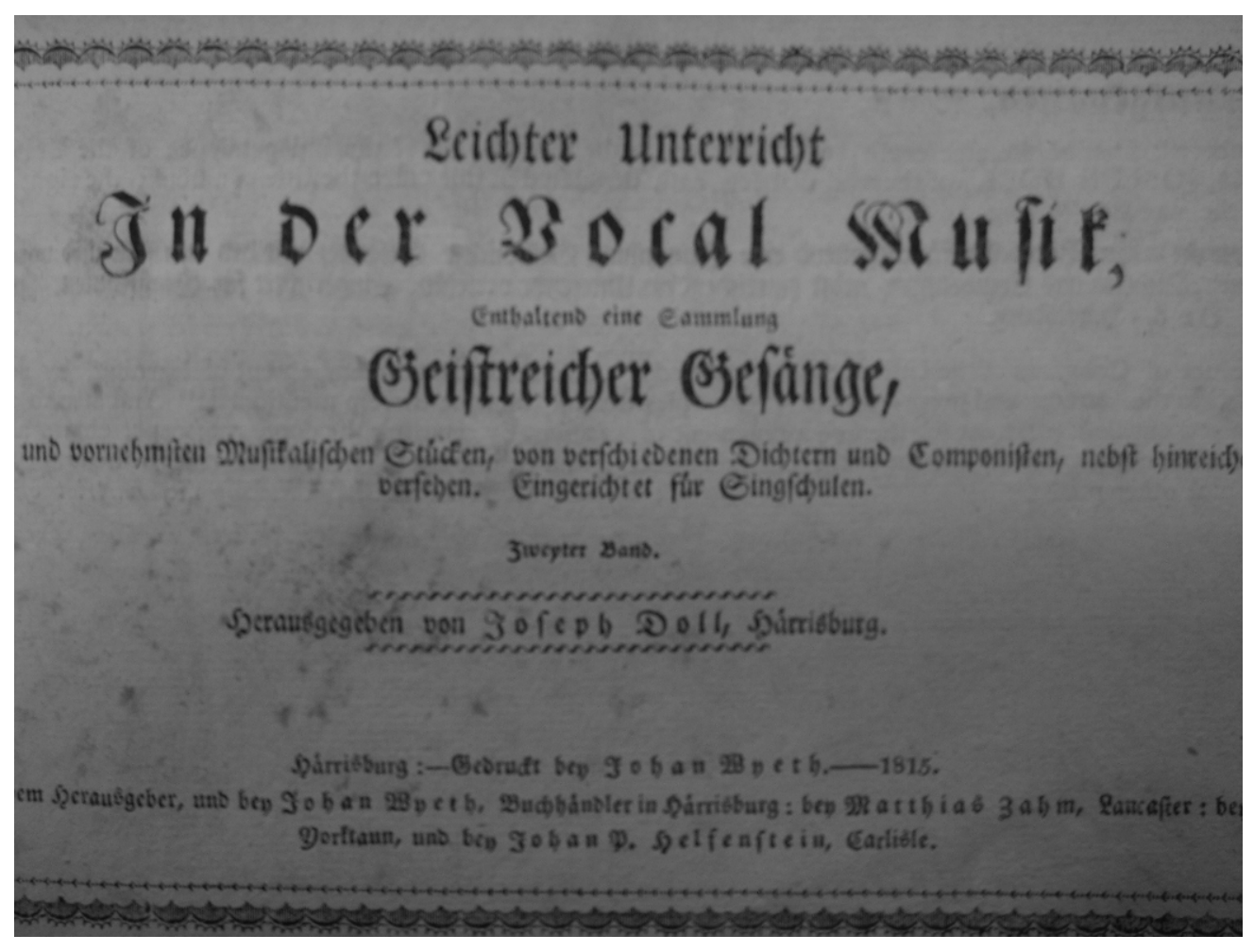

Figure 16 Title page of Joseph Doll's Leichter Unterricht, 1813.

The introductions of adaptive tunebooks also began to include "rudiments of music," which were noticeably absent from retentive tunebooks. Since these books were being used in singing schools and the younger generation was not musically literate, it was necessary to supply teachers and students with a foundation for reading and understanding music and its notation. These pedagogical prefaces often included at least the musical scale and instructions for solmization.

The song texts themselves also suggested an American influence. The Second Great Awakening brought revivalist themes to the theology of some Kirchenleute, affecting particularly a shift "from a theology of 'Justification' to a theology of 
'Sanctification." ${ }^{\prime 15}$ Though this change was not a complete about-face among Germans interested in Revivalism, its presence is noticeable in the sentimental texts found in some adaptive tunebooks, and the presence of fewer hymns focusing on the sacraments of the Church.

Adaptive tunebooks also contain new genres of music outside the European hymns and chorales of retentive tunebooks. Although the earliest books of this type still drew mostly on European sources, the fuging tunes, anthems, and, eventually, folk-hymns of the American shape-note tradition began to appear more and more frequently. Over time, American (or American-like) tunes became more prevalent within German tunebooks, eventually shifting the balance from German to Americandominated content. Accompanying the American influence on tune selection is an apparent move away from the two-voice figured bass setting of chorale books toward the three- and four-voice settings more common in Anglo-American hymnals. The melodic nature of the music changed as well, and tunes began to contain wider leaps and somewhat less consistently conjunct lines. This shift began to occur even in newly composed tunes by German authors, suggesting that the Anglo-American influence went beyond musical selection and began infecting taste and style. ${ }^{16}$

Since the tunes being adopted by adaptive tunebook compilers came from popular American collections, it is no surprise that printers began setting the music in shape-note notation. The four-shape method of Little and Smith is often used in

${ }^{15}$ Grimminger, 51-52. The Lutheran belief in "Justification" emphasizes that there is nothing a believer can do to earn God's salvation, salvation and faith was a gift from God to the Christian Church. Revivalism's "Sanctification" was the idea that believers became holy in God's eyes by accepting Jesus in their hearts.

${ }^{16}$ See Westermeyer, "The Evolution," 167. Westermeyer points to larger intervallic leaps as indicative of Anglo-American gospel hymnody. 
adaptive tunebooks (see fig. 17). Because this printing relied on moveable type, printers no longer produced books using engraved sheets or punch-plates, and so adaptive tunebooks took on the appearance of contemporary American shape-note collections.

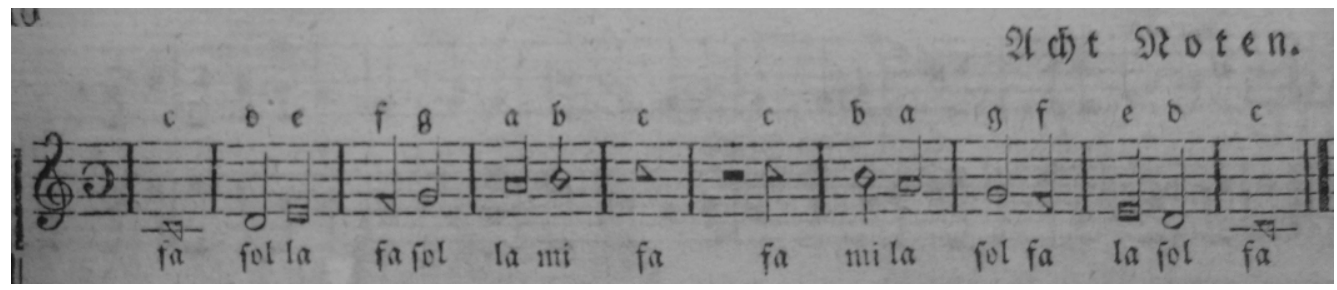

Figure 17 The eight notes of the "natural" scale with their proper shapes and solmization, from Joseph Doll's Leichter Unterricht, 1813 edition.

The publication of "adaptive tunebooks" and their gradual transition in look and contents toward Anglo-American models happened in less than twenty years (1810-1827). Significantly, all of the printed adaptive books surveyed by Grimminger were published in Harrisburg (excluding one Gettysburg publication) and compiled and/or printed by John Wyeth. ${ }^{17}$ Wyeth's connection to these works of mixed ethnic influence further demonstrates his awareness of the German population's attraction to shape-notes and American hymnody. The time and location are also important: these mixed German-American shape-note tunebooks come only from eastern Pennsylvania in the second and third decades of the nineteenth century.

This is the last stop before we cross the Mason-Dixon Line: the German population of Pennsylvania had already begun its southwestward migration to Western Maryland and the Shenandoah Valley. It is likely that the Lutheran and

${ }^{17}$ Grimminger, 146-65. 
Reformed communities who would one-day settle in these areas brought with them, in some form, the hymnody that they had been so fond of in Pennsylvania.

\section{Notenbüchlein}

Similar to the printed adaptive tunebooks studied by Grimminger, and closely related to the Brandstetter tunebook, are the manuscript Notenbüchlein collected and analyzed by Suzanne Gross. The Notenbüchlein were small, handwritten tunebooks containing a mixture of German and American tunes, ranging from monophonic chorale and hymn melodies to three- and four-voice choral arrangements. The books were produced by singing-masters in the Franconia Mennonite Conference as gifts for their most promising music students beginning in the late eighteenth century. This particular Mennonite group is found in the Pennsylvania counties of Bucks, Montgomery, and Chester, just north and west of Philadelphia.

Despite being a part of Grimminger's Sektenleute, the Franconia Mennonites were not isolationists. While their contact was limited to other Pennsylvania-German religious groups, their interaction with Lutheran and Reformed believers gave them

exposure to Kirchenleute hymnody. ${ }^{18}$ Because of this, the Anglo-American influences observed in the adaptive tunebooks of the Kirchenleute are reflected in the Franconian Notenbüchlein.

Franconian Notenbüchlein take the oblong shape of other American tunebook collections, measuring on average $9.5-10$ by $15.5-17$ centimeters. The title pages make use of Pennsylvania-German Fraktur and include the owner's name, the year of compilation, and usually the name of the singing school attended by the student.

${ }^{18}$ Gross and Berg, 191. 
Often following the title page is a short "Introduction to the rudiments" section that varies in length and content from book to book. Still, explanations concerning notation are regularly included until 1817, and the four-syllable-fa-sol-la-misystem is more often used than the German alphabet system for the naming of notes. Also beginning in 1817, shape-notes are used for notation, complimenting the apparently popular four-syllable solmization method. ${ }^{19}$ Musically, the contents of these manuscript books rely heavily on German sources, though there are inconsistencies in the melodies between different Notenbüchlein (usually as created through the addition of passing tones). Gross and Berg believe that these deviations come from the singing-master transcribing melodies for students from an oral tradition, and that the changes from the main melody are embellishments added by individual singers. ${ }^{20}$ In addition, a small but significant number of tunes come directly from the Anglo-American tradition, including thirteen identified fuging tunes and twenty hymn tunes, implying contact with the American sacred music tradition. ${ }^{21}$

It is significant to recognize the connection Notenbüchlein have with the adaptive tunebooks, especially the adoption of Anglo-American tunes and notation. These shared traits suggest that the Franconia Mennonites (Sektenleute) interacted with the Lutheran and Reformed Germans (Kirchenleute), allowing the Mennonites to learn the American hymn tradition through this relationship. Equally important, the

${ }^{19}$ Gross, 53-66.

${ }^{20}$ Gross and Berg, 194-202.

${ }^{21}$ Ibid., 172-174, 204-208. Suzanne Gross has pointed to Wyeth's Repository of Sacred Music, Part Second and the Kentucky Harmony as the main sources for the shape-note tunes. Her study of shape-note hymnody, however, is not particularly in depth. 
creation of Notenbüchlein in Franconia Mennonite singing schools may have influenced Lutheran or Reformed local singing-masters to create personal tunebooks for their own students. Alternatively, the existence of Notenbüchlein in the Franconia Mennonite Conference in Pennsylvania may indicate a broader cultural practice shared by other German singing-masters of differing denominations. Understanding the characteristics of adaptive tunebooks and Notenbüchlein is significant to this thesis because the Brandstetter tunebook shares a number of characteristics with both forms of written music, further suggesting a connection between the Kirchenleute, who will bring their musical culture into Maryland, and their Sektenleute neighbors. In short, the immigrant Germans of Pennsylvania brought to America a wellestablished sacred music tradition based on the singing of chorales. Despite its longstanding place in their culture, the developing American hymnody had a certain appeal, especially for the younger, more Americanized generations of Lutheran and Reformed Germans. Because of this, German and American influences can be seen comingling on the pages of German-American tunebooks (published mainly in Harrisburg) near the beginning of the nineteenth century. Over a short span of just two decades, the balance of music in the tunebooks tipped toward the American style as it slowly supplanted the German chorale tradition. Contemporarily, Franconian Mennonite singing-masters were producing handmade Notenbüchlein during the late eighteenth and early nineteenth centuries. Beginning in the early 1800s, these manuscript tunebooks began to share a number of characteristics with the Lutheran and Reformed adaptive tunebooks. These shared qualities demonstrate an exchange between differing denominations within the German community and open the 
possibility that Notenbüchlein were a product of other German communities outside the Franconia Mennonites. The musical culture of the Pennsylvania Dutch, represented by adaptive tunebooks and Notenbüchlein, accompanied the German population of Pennsylvania migrating into Western Maryland where the tunebook of Maria Brandstetter was produced. 


\section{Chapter 4: The Germans and Shape-Note Hymnody in Western Maryland}

We know very little about music in the frontier region of Maryland at the beginning of the nineteenth century. The German immigrants settling the area were reported to be hard-working farmers, laborers, and craftsmen, but rarely are there descriptions of professional musicians or musical activities. ${ }^{1}$ Despite this state of affairs, the pious quality of the population and their roots in the long musical tradition of Germany would have required some form of sacred music performance. Though rare, extant printed and manuscript sources from the region give a consistent view of musical life in the mountains, where German and Anglo-American influences intermingled, and connections to the developing American folk-hymn tradition were made.

\section{German-American Hymnody in Western Maryland}

Given that the majority of Germans in Western Maryland at the beginning of the 1800s came from Eastern Pennsylvania, the cultures in the two locations were quite similar. Tunebooks from the mountains of Maryland reflect the divided German and American influences observed in the Pennsylvania Dutch "adaptive tunebooks" and Notenbüchlein. ${ }^{2}$ While migrating Pennsylvania Germans brought their music and books across the Mason-Dixon Line, this is only part of music's story in Western Maryland. There is evidence that the Germans of Maryland were actively creating

\footnotetext{
${ }^{1}$ Any evidence of music in the region around the turn of the century is in the form of local newspaper advertisements either for music lessons or singing schools, but these are occasional at best.

${ }^{2}$ Grimminger, 143-146; Gross, "Notenbüchlein," 45-74.
} 
tunebooks that would serve the sacred music needs of their community, even before the popular German-American tunebooks were printed in Pennsylvania.

In Hagerstown, Maryland, a tunebook compiled and edited by the local church musician Adam Arnold was issued by the press of prominent Washington County printer Johann Gruber in 1803. The tunebook was entirely in German, and the shortversion of the title read Geistliche Ton-Kunst (Spiritual/Sacred Music). It was of the typical oblong shape and contained the usual pedagogical introduction of contemporary Anglo-American tunebooks. The book's contents are divided between German chorales and other non-chorale, sacred choral works. Many of the nonchorale-based pieces are from the Anglo-American hymn tradition and were given English titles-though the texts are entirely in German. Geistliche Ton-Kunst, then, can be considered an adaptive tunebook: the book's format, introductory material, and musical selections are partially from the Anglo-American tradition, though the German language and chorales are the dominant features of the collection. Interestingly, this Western Maryland tunebook predates the adaptive Pennsylvania tunebooks studied by Grimminger, the earliest of which dates from $1810 .^{3}$

The contents of the book are clearly divided along German and American lines. Of its sixty-four tunes, thirty-nine are from the standard chorale repertoire and twenty-two carry English tune names and style traits; the remaining songs are chorale-like German pieces. In the index to the tunebook, Arnold separates the two types of tunes, despite their being mixed within the book's pages. ${ }^{4}$ The AngloAmerican tunes are taken directly from the American hymn tradition, which began in

\footnotetext{
${ }^{3}$ Wolf, 303-306; Grimminger, 147-51.

${ }^{4}$ Wolf, 306-309.
} 
New England nearly half a century earlier, and the book includes a number of old favorites, such as MEAR. Arnold defends his inclusion of the non-German pieces in his foreword, writing that "this work also includes a number of excellent musical selections for the inspiration and use of young people for singing." This illustrates that the divide in generational tastes observed in Pennsylvania Dutch adaptive tunebooks was also at work among Maryland Germans. ${ }^{5}$

Despite the forward-looking nature of Arnold's compilation, there were areas for improvement. At the time of printing, Johann Gruber did not own any musical typeface; because of this, the words and staves were printed, but the notes were drawn in by hand. This certainly limited the supply of available tunebooks and made the idea of multiple editions a rather tedious (and apparently non-existent) prospect. ${ }^{6}$ Also, Western Maryland was a rural frontier region, inhabited by rugged farmers and laborers more than educated professionals. This meant that musical literacy was an issue, just as it was in the rural areas of the Northeast and New England. The effectiveness of singing schools has been demonstrated, and the popularity and preference for shape-notation in the schools was made even more apparent by the incorporation of shaped-noteheads into German tunebooks and Notenbüchlein beginning in 1810. Arnold's book, however, did not use shape-notes; whether this was due to preference or ignorance is not known, though the latter seems more plausible, given that shape-notes were quickly becoming popular within the German communities of Pennsylvania. Also, Little and Smith's Easy Instructor (1801) did not

\footnotetext{
${ }^{5}$ From the foreword to Geistliche Ton-Kunst, quoted and translated in Wolf, 306.

${ }^{6}$ Wolf, 304.
} 
have wide success until its 1805 Albany printing, postdating Arnold's 1803 compilation. $^{7}$

The apparent geographic range of Geistliche Ton-Kunst is also worth noting. Remembering that shape-note hymnody would be passed from Eastern Pennsylvania into Virginia, it is significant that the one extant copy of Arnold's tunebook belonged to Rebecca Henkel of New Market, Virginia. ${ }^{8}$ New Market lies just twenty miles north of Harrisonburg, the home of the Kentucky Harmony compiler, Ananias Davisson, and about fifty miles south of Winchester, a hub for shape-note publications in the Shenandoah Valley beginning in $1832 .{ }^{9}$ Edward Wolf theorizes that Rebecca was a member of the Henkel family of Lutheran pastors and publishers in New Market. He also discovered that Maryland's Johann Gruber supplied the type used by the Henkels when they established their press in $1806 .{ }^{10}$ This shows that years before John Wyeth's publications, there was cultural exchange between Marylanders and Virginians of the Shenandoah Valley, and that early American hymnody was in the Valley via a collection created by a Western Maryland compiler.

The presence of Arnold's 1803 tunebook in Maryland indicates that Germans living in the western mountains sought a medium for sacred music performance before the major publications of John Wyeth (which began in 1810). That a copy of the tunebook came from the Shenandoah Valley and that the book's printer, Johann

\footnotetext{
${ }^{7}$ Lowens and Britton, 38.

${ }^{8}$ Wolf, 304. The tunebook is part of Chicago's Newberry Library collection.

${ }^{9}$ For background on pre-Civil War shape-note tunebooks in Virginia, see Eskew.

${ }^{10}$ Wolf, 304. Through Henkel, it is also possible to connect Gruber to German shape-note printer Joseph Funk of Singer's Glen, Virginia, but this is a topic beyond the scope of this thesis.
} 
Gruber, was doing business in New Market demonstrates a connection between Valley-communities and residents of Western Maryland. Most importantly, Geistliche Ton-Kunst offers proof that American hymnody had flowed into Western Maryland on its southwestward journey, leaving open the possibility for shape-notes, and that the growing repertoire associated with the notational system had become part of the musical culture in the region.

\section{Maria Brandstetter's Tunebook}

It has long been suspected that shape-notes played a role in the musical environment of Maryland, but to date there has been little hard evidence in support of this assumption. The personal tunebook of a German woman living in Western Maryland finally supplies scholars with a primary source demonstrating the styles and genres present in the mountains between Eastern Pennsylvania and the Shenandoah Valley.

As we shall see, the Brandstetter family history is a model of the Germanimmigrant experience in the late eighteenth and early nineteenth centuries, and the tunebook's format and contents are indicative of contemporary adaptive tunebooks and Notenbüchlein. These characteristics connect the Brandstetter source with the people and culture moving from Pennsylvania into Maryland and Virginia. The book also reveals the printed musical sources being used in Maryland and the state of musical culture among the Western settlers. Finally, the tunebook's origin in Western Maryland provides another stepping stone for the southward dissemination of shapenote hymnody. 
The small and oblong Brandstetter tunebook begins with a handwritten title page reading, "Maria Brandstetter's Melodie und Sing-Buch in Waschington (sic) County: Maryland. 1820." Below this, a descendant of Ms. Brandstetter wrote "Great Grand Mother's song book" (see fig. 1 above). Similar to the Notenbüchlein studied by Gross, the title page gives us a name, location and date of origin. But who was Maria Brandstetter?

Sometime in the mid-eighteenth century, Johann(es) Mathias Brandstetter brought his family to the New World from Germany. The first records of their existence in the Colonies are land grants from 1770 in Frederick County, Maryland, though they were likely on American shores at an earlier date. ${ }^{11}$ Mathias had three children: Barbara, Andrew, and the youngest, Matthew, who joined Maryland's militia during the Revolution in 1777. The 1790 census places an Andrew Brandstetter_possibly Mathias's brother (Andreas) or eldest son (Andrew)—in Dauphin County, Pennsylvania (the county surrounding John Wyeth's headquarters in Harrisburg). The 1800 and 1810 censuses show that the Brandstetter clan was thriving in Western Maryland with three Brandstetter men (including Andrew, who had moved from Dauphin) living with wives and children in the area.

At the turn of the nineteenth century four possible "Maria" Brandstetters were living in Washington County, Maryland. The eldest, Magdelena, was a daughter-inlaw of the first settler, Mathias. She was also the grandmother of the three other "Marias." Little is known about these young Brandstetter girls, as their marriage

${ }^{11}$ The records regarding the history of the Brandstetter family came from the Washington County, Maryland Historic Society where a Brandstetter family file is available for review. 
records have not been found, making them nearly impossible to track. It is certain that one of the granddaughters, Marianna, was baptized in 1804 at the German Reformed church in Hagerstown. The other two "Marias," Mary and Mary Ann, were sisters, and Marianna's cousins. Mary's and Mary Ann's birthdates are unknown, but their eldest sister, Elizabeth, was baptized in the same church as Marianna in 1801, likely making their births sometime within the next decade or so. ${ }^{12}$ Though ownership of the tunebook cannot be determined with certainty, its format and contents may provide hints about who "Maria" was, while also shedding light on shape-note hymnody in Western Maryland.

The entire book is handwritten, although the staved pages may have been produced ahead of time as the staves are identical and line up perfectly throughout the book. Following the title page is a brief, one-page "rudiments" section (see fig. 18). The rudiments consist of one large stave split between treble clef on the left and bass clef on the right, with note names given to every line and space. The scale is written out in shaped-notation according to a natural key signature, and all the possible durations from whole-note to eighth-note are given. Below the scale is a short explanation of how to locate $m i$ (the leading tone) in keys of up to four accidentals in either the sharp or flat direction. All titles and explanations are in German. The musical content is a mixture of German, chorale-based works and English tunes in the

${ }^{12}$ Interestingly, the parents of Mary and Mary Ann were married in 1798 in the Evangelical Lutheran church in Hagerstown, rather than the Reformed church used for their daughter's baptism. This fact reflects the unity between the two denominations discussed earlier. 
American idiom. There are sixty-one tunes on sixty-five pages, of which thirty-one are German and twenty-nine are American. ${ }^{13}$

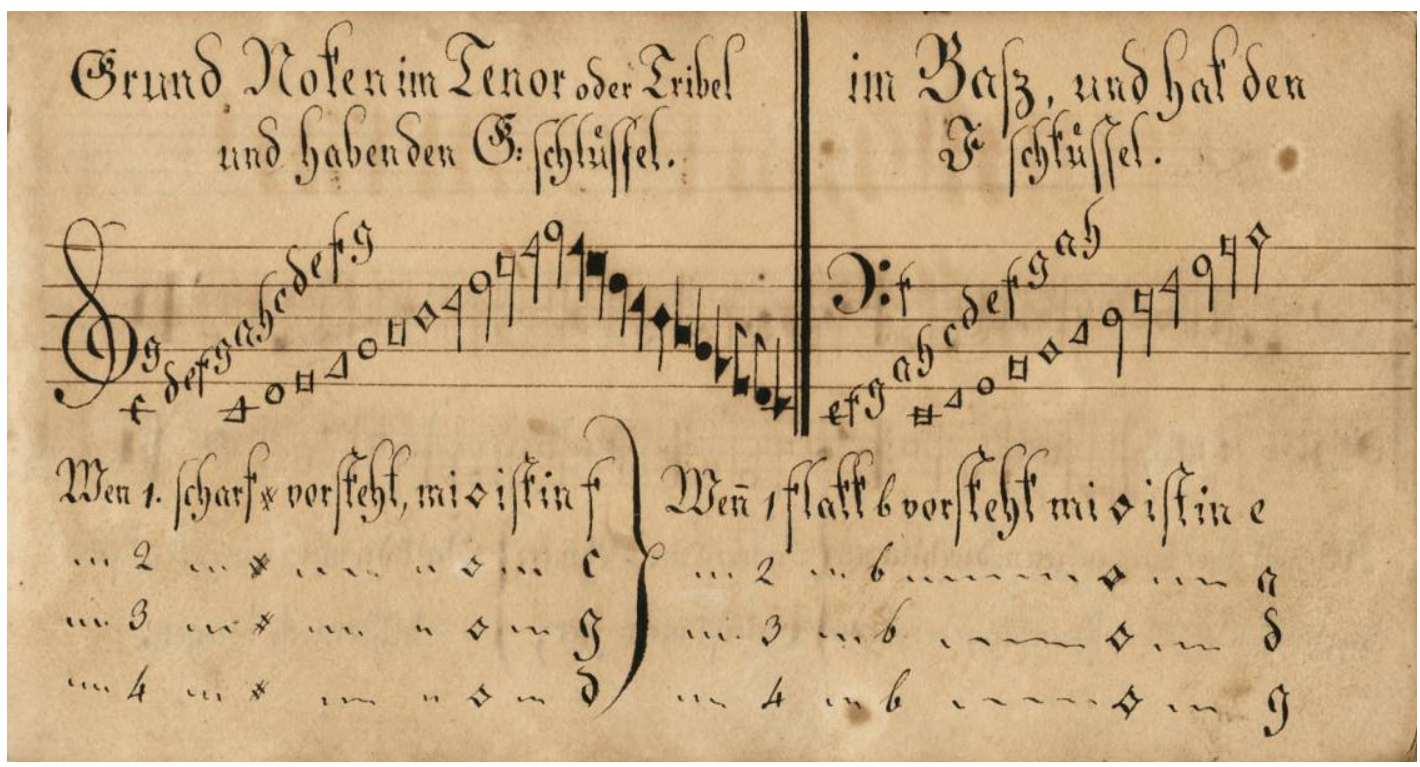

Figure 18 The "rudiments of music," with the musical gamut in two clefs and a short explanation of key signatures.

Two different styles of handwriting are observable in the texts (the music remains consistent throughout) and they are specifically connected to language. The German texts are written in nineteenth-century Fraktur. The English tunes are written using a neat cursive script in the same colored ink (see fig. 22). The number of German tunes outweighs American songs in the first half of the book, with the balance shifting toward American tunes in the second half, but there is no clear pattern to the songs' order. To a degree, the order of works reflects the manner in which many American tunebooks of the time were set up, with more difficult or intricate tunes placed near the end of the collection, though this is not strictly followed in the Brandstetter tunebook.

${ }^{13}$ For an index to the Brandstetter tunebook, see the appendix on page 93. 
The German works come from the chorale tradition; of the thirty-one tunes, twenty-two can be found by their text incipit in Zahn's collection of chorale melodies. ${ }^{14}$ These tunes are in the European style, set in two parts with the melody in the upper voice and a supporting line in the lower voice, which would have served as the foundation for a figured bass, though no figures are given. The melodies themselves do not match perfectly with those that Zahn printed, but the differences appear to be embellishments typical of folk-singing (recall that embellishments were often written in as passing tones in Pennsylvania Notenbüchlein). There are no titles given, and the texts for these songs are entirely in German (see fig. 19). Of the tunes that were not connected directly to chorale melodies in Zahn (texts that either did not match their corresponding tunes or were not in Zahn's index), seven were in the same two-part style with a mostly conjunct melody expected of the chorale.

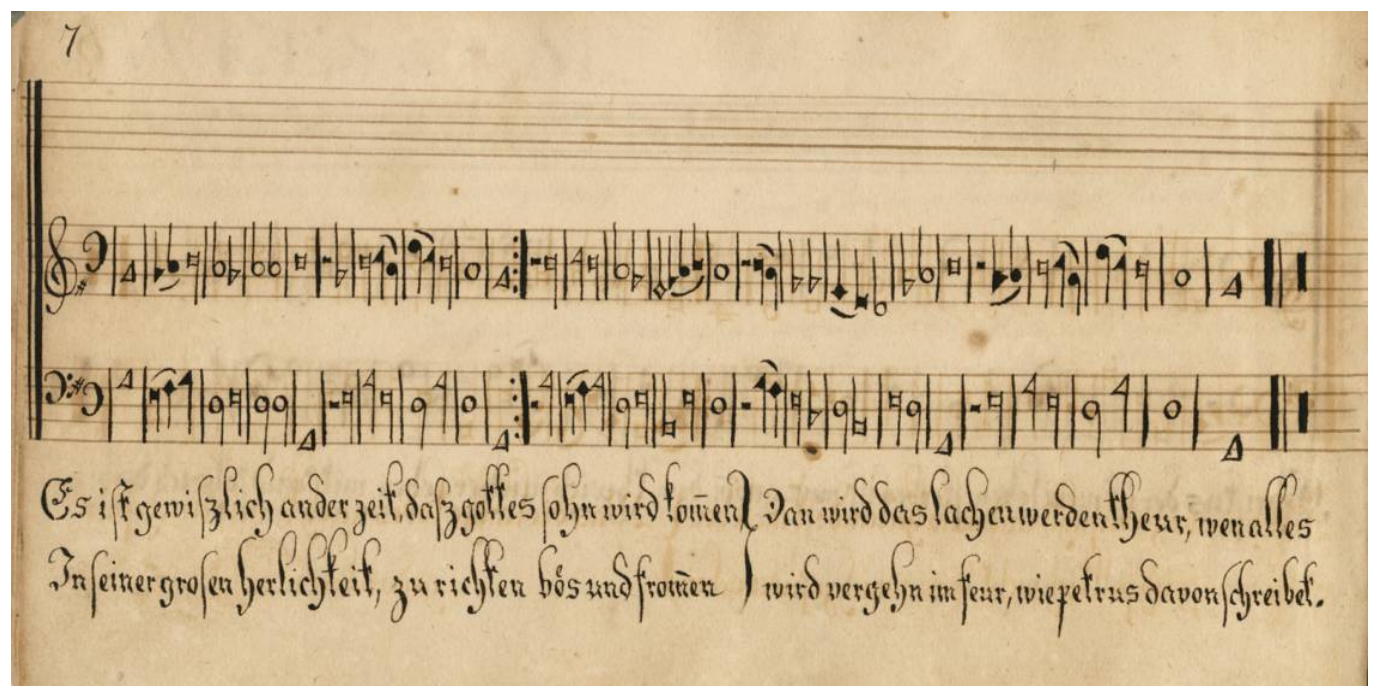

Figure 19 Chorale tune "Es ist gewisslich an der Zeit" in the Brandstetter tunebook (Zahn: 4429).

${ }^{14}$ Johannes Zahn, Die Melodien der deutschen evangelischen Kirchenlieder (Hildesheim: Olms, 1963). 
Two pieces with German-only texts show signs of American influence. One of the works is a fuging tune, following the sectionalized format of the style perfectly. Both works are set in three voices, with each voice showing melodic interest and not simply supporting harmony (see figs. 20 and 21). It should be noted that all the German tunes use shape-notes.

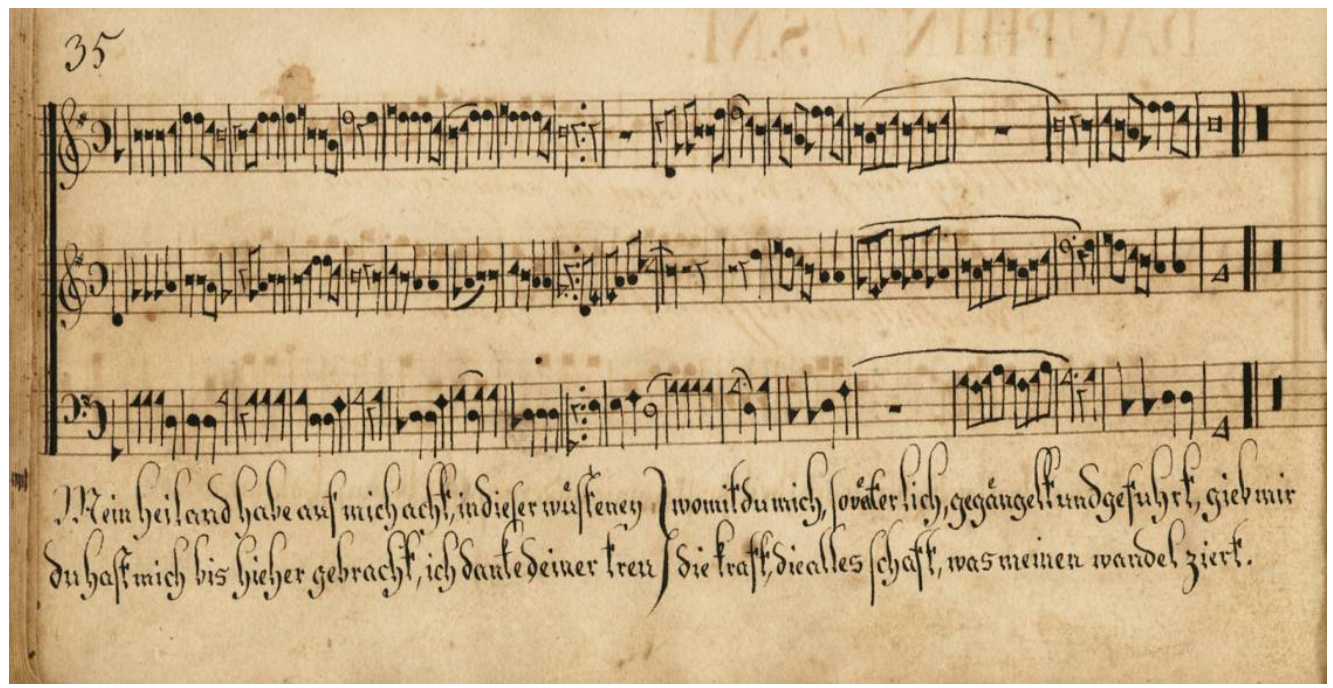

Figure 20 The song is clearly a fuging tune, yet the text is entirely in German and there is no tune name given.

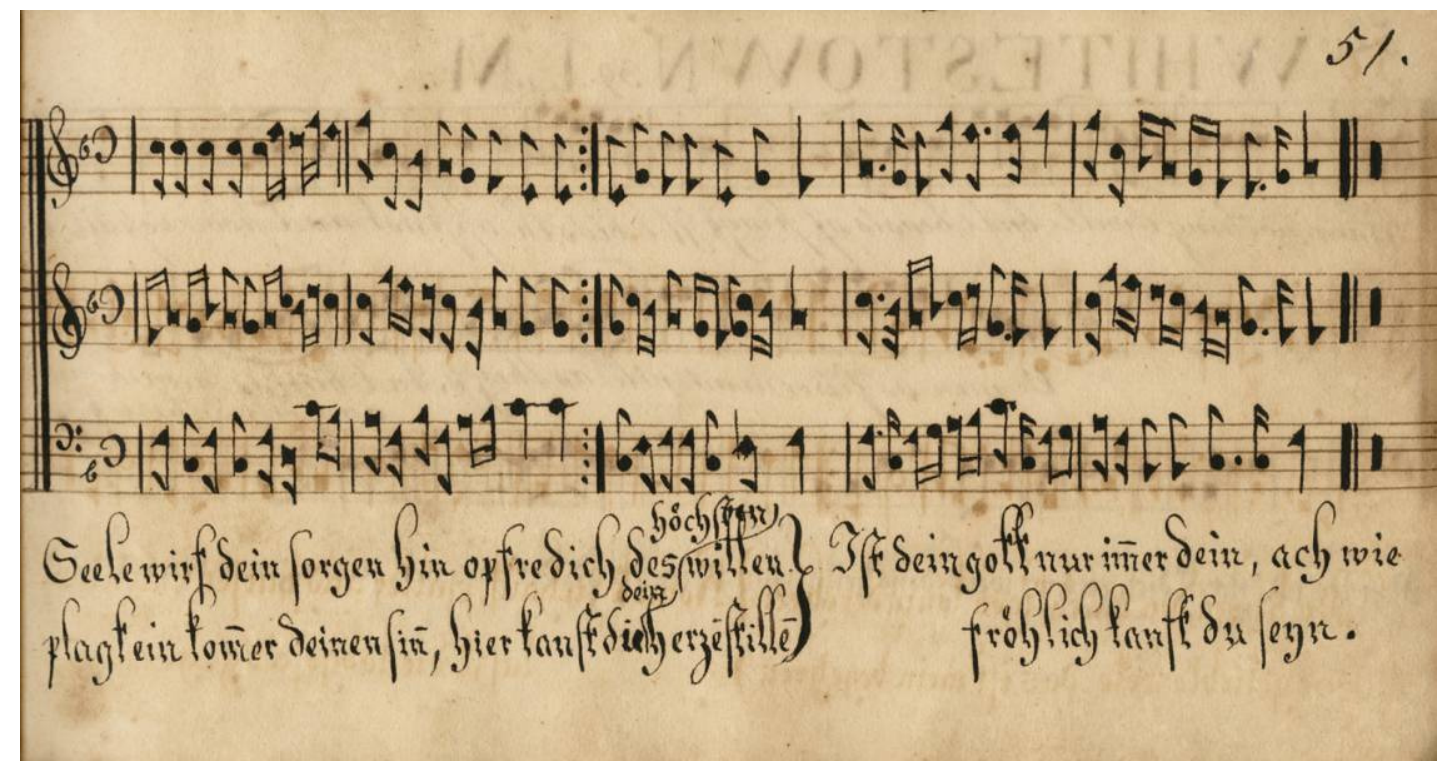

Figure 21 Three-part setting in the vein of American hymnody, but with only a German text. 
The source of the chorale tunes is uncertain, though a logical guess would be Heinrich Helmuth's Choral-Buch für die erbauliche Lieder-Sammlung. The ChoralBuch, published in 1813, was America's first official Lutheran chorale book, though it showed European influence in setting the chorales as melodies with figured bass, just as in the Brandstetter book (minus the figures). Adam Arnold's Geistliche TonKunst also seems like a reasonable source, because it was a local book and apparently quite popular. Twenty-one of the chorale melodies in the Brandstetter tunebook are also found in Geistliche Ton-Kunst, but a number of these tunes use different texts, and Arnold's chorales are set in four-parts, unlike the typical Germanic two-part style. Also, all of the chorale melodies in Arnold's book appear later in the 1813 Choral-Buch (so these melodies are also common between the Brandstetter book and the Choral-Buch), furthering the argument for Helmuth's book as the chorale source. $^{15}$

The English-language tunes in the book cover the history of American hymnody through the first decade of the nineteenth century. With only one exception, all of them are set in three voices using shape-notation and are given titles with corresponding poetic meters and numbers. The texts within the music are in English, but a German verse is always given at the bottom of the page. These verses are not translations of the English; some are well-known chorale verses, while others are simply German texts with sacred themes fitting the meter of the tune (see fig. 22).

\footnotetext{
${ }^{15}$ Wolf, 305.
} 


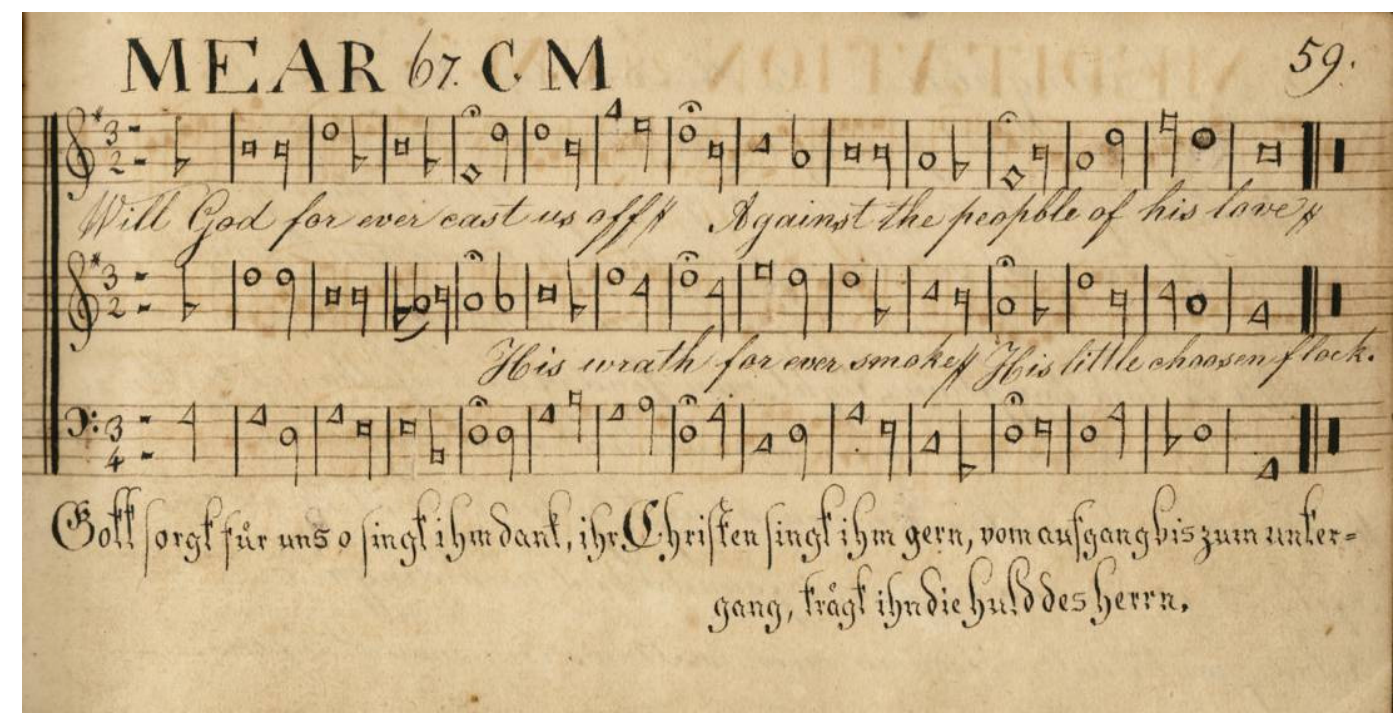

Figure 22 MEAR from the Brandstetter tunebook.

The one exception is the tune SAMANTHA (sic, normally spelled SAMANTHRA in the shape-note tradition, the spelling used here). For SAMANTHRA, only two voices (lead and bass) are written out, though the tunebook's creator may have planned on providing a treble, since the bars were drawn out on the top stave- a feature not seen in the two-part chorales. SAMANTHRA also lacks a German verse, and the bold titling, meter, and number are replaced by cursive handwriting and the key of the tune-"Flat Key on A" (see fig. 24). The tune will be described in more detail below.

The numbers accompanying each tune correspond exactly to those of Wyeth's Repository of Sacred Music, the source of the American tunes. The three voice parts are also exact matches to the treble, tenor, and bass parts printed by John Wyeth. While the Repository is clearly the source, it is more difficult to determine which of his editions was used. The first edition from 1810 can be eliminated, since the tune VIRGINIA does not have the same number in the Brandstetter book as it does in 
Wyeth's (this was one of the few tunes that saw a number change between Repository editions). The second through the final fifth editions match the tune numbers within the Brandstetter book, making all of them possible sources from which the American hymn tunes were copied. ${ }^{16}$ The fourth edition is the latest likely source, given that its publication date is 1818 , two years before Maria Brandstetter's book was dated. The fifth edition was published in 1820 , and it seems less likely that the Western Maryland Germans would have already obtained, used, and then created a personal tunebook from it within the same year.

If either of the second or third editions served as the main source for American tunes, then the Brandstetter tunebook shows that Wyeth's publicationswhich served as models for Ananias Davisson's Kentucky Harmony (1816)—were known and used in Western Maryland before Davisson's first tunebook compilations. This circumstance would suggest that the migrating German population brought shape-note music into the Valley, possibly exposing Davisson to the hymnody he would help make famous throughout the South. If either the 1818 or 1820 edition were the models for the Brandstetter tunebook, the presence of Wyeth's collection in Western Maryland is still significant in that it brings shape-note hymnody seventy miles closer to the Shenandoah Valley than previous evidence has shown, filling in a gap between important shape-note compilers and connecting the music to the population migrating between Eastern Pennsylvania and Virginia.

${ }^{16}$ The publication dates for these editions are $1811,1812,1818$, and 1820 , respectively. It should also be noted that the copy of the third edition viewed by the author was incomplete, though all of the tunes within the extant portion matched the Brandstetter book. As the third edition contains the same number of pages as the fourth and the contents remain the same minus one tune (which is not in the Brandstetter book), the 1812 edition likely resembles the 1818 version. 


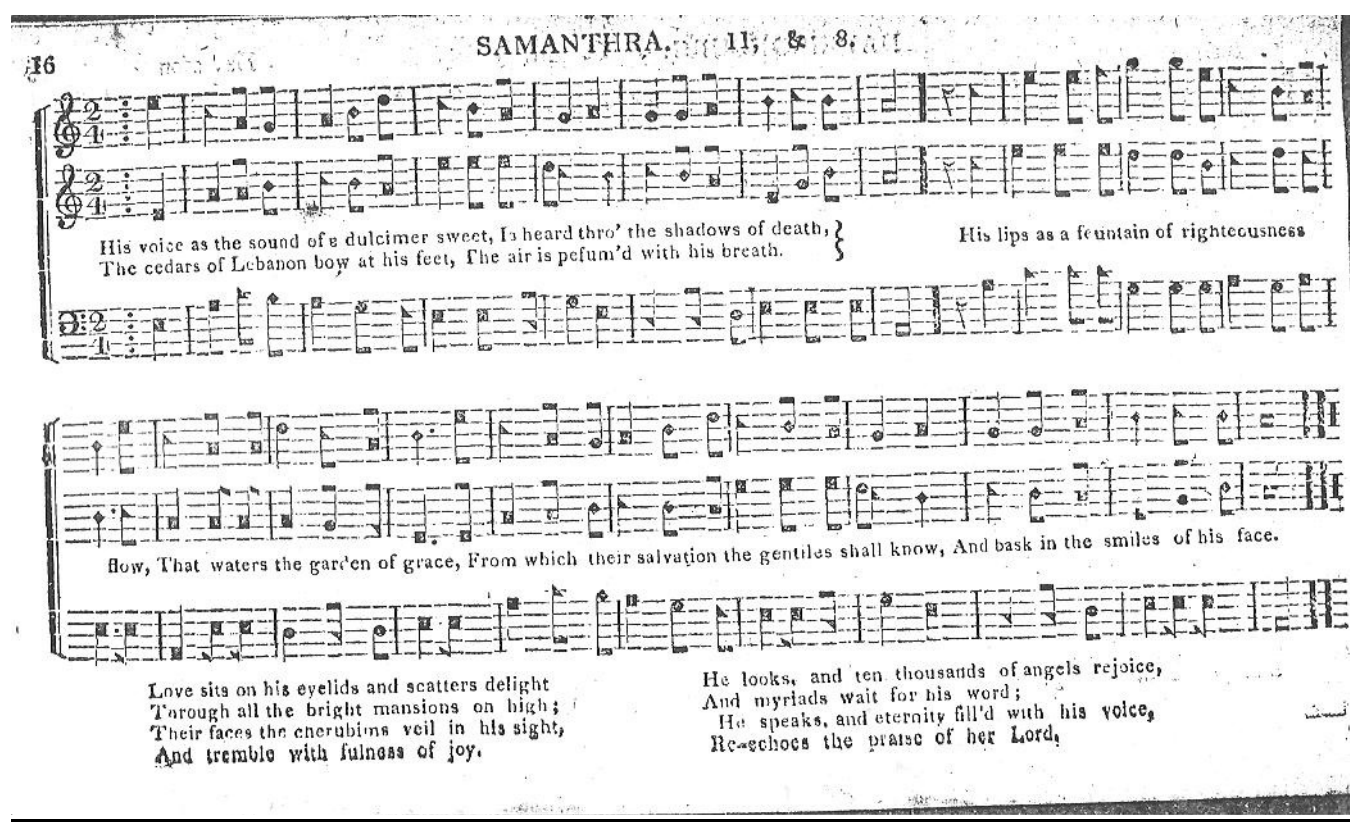

Figure 23 SAMANTHRA from Davisson's Supplement to the Kentucky Harmony, reproduced from an 1825 edition owned by Berkley Moore, http://www.shapenote.net/berkley/SKyH3.htm. The setting did not change between the second and third editions.

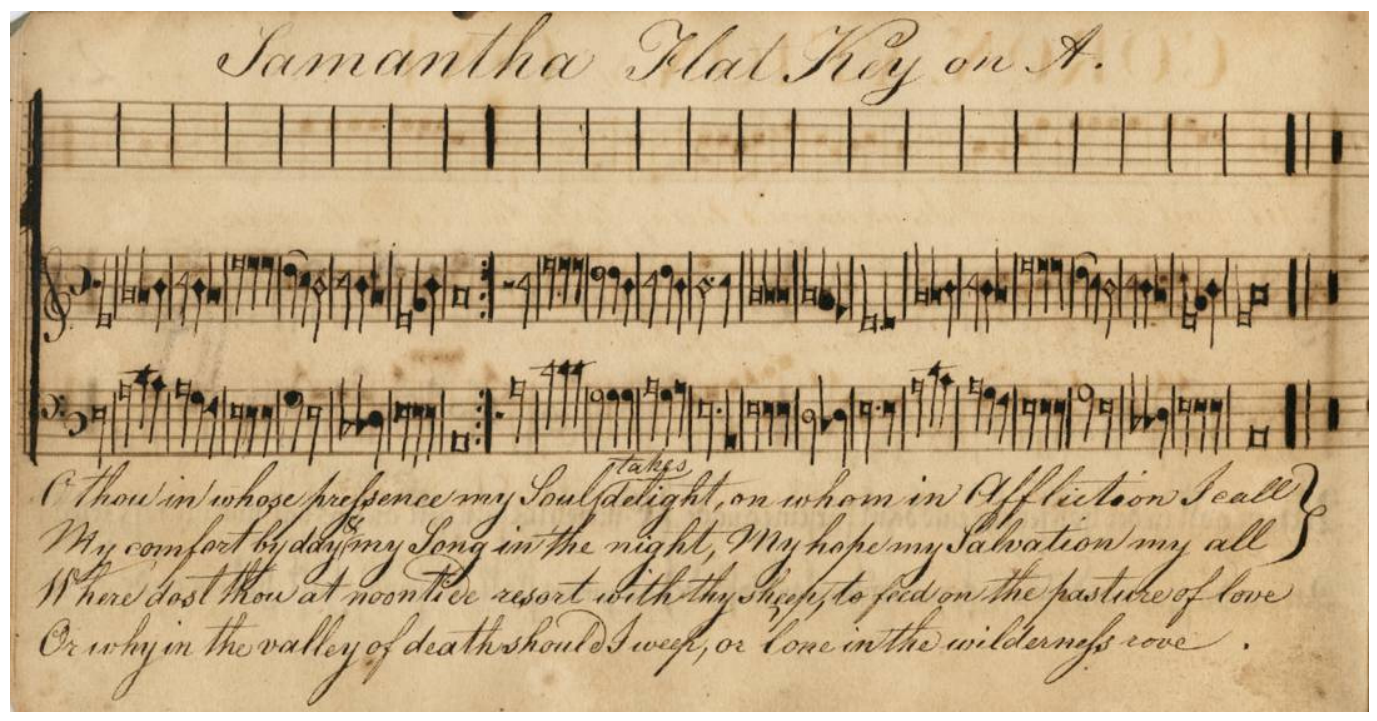

Figure 24 SAMANTHA (sic), as prepared for the Brandstetter tunebook. Note the style of the title and the empty, but measured, top stave. 
The exceptional tune, SAMANTHRA, requires attention as it provides some interesting insights into the history of Maria Brandstetter's book. The first person to print SAMANTHRA was Ananias Davisson, but he did not publish the tune until the second edition of his Supplement to the Kentucky Harmony, which dates from ca. 1821-24, at least a year after the 1820 date written on the title page of the Brandstetter book (see fig. 23). ${ }^{17}$ As SAMANTHRA is written only in English and does not appear to be as carefully set as the other tunes within the Maryland tunebook, it may have been a later addition onto a page that was initially left blank. This opens up the possibility that the 1820 date on the Brandstetter book is not so much a finishing date as the year when compilation of the book began. There are two later editions of the Repository (1826 and 1834), but these "enlarged and improved" (Wyeth's words) versions had a larger proportion of "second-rate European hymntunes which had all but snuffed out the American idiom in large urban centers by 1826." These final two versions also contained a large number of typesetting errors in the old American tunes. ${ }^{18}$ Neither of these later characteristics is reflected in the Brandstetter tunebook, however, making it quite unlikely that the Maryland tunebook was compiled from the 1826 or 1834 Repository editions.

There are also textual and musical discrepancies between the Brandstetter version of SAMANTHRA and that found in Davisson. Davisson's first verse begins "His voice as the sound of a dulcimer sweet;" the verse used in the Brandstetter book begins "O thou in whose presence my soul takes delight." There are additional verses

${ }^{17}$ Richard J. Stanislaw, A Checklist of Four-Shape Shape-Note Tunebooks (Brooklyn: Institute for Studies in American Music, 1978), 7.

${ }^{18}$ Lowens, "Introduction," ix. 
given below the music in each book, but there are no shared lines. There are also two slight alterations in the bass line between Davisson and Brandstetter (see figs. 23 and 24). To further complicate matters, all of the verses from both Davisson and Brandstetter can be found in Wyeth's Repository, Part Second (1813) accompanying the tune DAVIS, showing that all the verses are from the same hymn text. Of course, SAMANTHRA is printed in later tunebooks, as well, using verses from both the Brandstetter book and Davisson's publication. ${ }^{19}$

Because of all the deviations and subtle changes, there is no clear way of knowing the exact source for SAMANTHRA. But if the late addition of SAMANTHRA was from Davisson's work and we take the 1820 date on the Brandstetter tunebook as the year of its creation, the relationship with the Supplement to the Kentucky Harmony may further indicate exchange between the Germans of the Shenandoah Valley and those living around Hagerstown, deepening the connection between the two regions and their inhabitants.

\section{Identifying Maria Brandstetter}

Turning back to the question of ownership, we must consider how the typical singing school worked. As described earlier, participants were normally young people, often teenagers. Magdalena (the eldest "Maria") Brandstetter's birth and death dates are uncertain, but the 1800 census lists her as being between the ages of twenty-five and forty-five. By the 1810 census, she was over forty-five years old. Assuming the youngest possible age, Magdalena would have been born by 1764 . Her will was administered in 1832. Assuming that was the year of her death, the youngest

${ }^{19}$ The most popular of these books are The Missouri Harmony (1820) and the Southern Harmony (1835). 
Magdelena could have been was sixty-eight years old. Though this is a fairly long lifetime, this would make her husband seventeen years her elder. While possible, it seems more likely that she was older, maybe by more than a decade. Even still, Magdalena would have been at least fifty-six years old when the Brandstetter tunebook was made_-significantly older than the average singing school participant.

The younger "Maria" candidates were probably born sometime between 1801 and 1811 (considering baptismal dates and their siblings' ages), meaning that in 1820 they would have been between the ages of nine and nineteen, with Marianna (whose birth year is almost certainly 1804) about sixteen years old. This age range is far more typical of singing school students. Since the tunebook shows a number of qualities similar to the Notenbüchlein discussed earlier, i.e. mixed German and American influences, handwritten, personalized, shaped-notation, the idea of the Brandstetter tunebook being a gift for a promising young music student seems reasonable.

Maria Brandstetter's family history and tunebook fit well within the history and music of German-immigrant families in early nineteenth-century America. The family's presence between Dauphin County, Pennsylvania and Washington County, Maryland, places them along the migratory route many Germans followed beginning in the eighteenth century. The characteristics of the Brandstetter tunebook show a mixture of German and American influences: it contains music from both ethnic traditions, English and German texts, and a format reminiscent of American publications. Its 1820 date places the book within the time period when other published and personal adaptive tunebooks have originated. The location in Western Maryland offers physical evidence of the type of sacred music performed by Germans 
in the region. Finally, the tunebook's shape-note hymns can be traced back to their original published source, giving the book a place within the chronology and geography of shape-note hymnody between the influential Pennsylvania publication of John Wyeth in 1810 and the pivotal Kentucky Harmony of 1816, compiled by Ananias Davisson in Virginia.

\section{Conclusions}

The Brandstetter tunebook and the story of its creation help bring into focus a broader historical, cultural, and musicological picture of early nineteenth-century America. Analysis of the book's contents and the Brandstetter family history enlightens our understanding of German-American immigrants migrating from Pennsylvania into Maryland and Virginia at the beginning of the nineteenth century. The tunebook's origin in Washington County reveals what musical life might have been like along Maryland's mountainous frontier. Finally, the book's connection to the shape-note tradition deepens our knowledge of the southward dissemination of American folk hymnody across the Mason-Dixon Line and into the Mid-Atlantic.

Most studies of German-immigrants look at the Pennsylvania Dutch and their activities. Here we find isolated communities, torn between retaining their foreign musical heritage while assimilating aspects of their new home country. The tension between these two sides is apparent in their printed music. German hymnbooks that once contained only chorales and sacred songs of the Old World began to show Anglo-American traits, such as "rudiments" of music, fuging tunes, new melodic contours, and shaped-notation. These adaptive tunebooks were most present in the 
early part of the nineteenth century, demonstrating the transitional period between cultural retention and assimilation.

Around this same time, at the beginning of the 1800s, the singing school institution of New England was making its way toward the Mid-Atlantic region, chased from its birthplace by reformers trying to teach "better music" to the public. The German communities of Pennsylvania adopted the singing school tradition, along with some of its resources and music. This type of musical education is reflected in the Notenbüchlein, which were handwritten, personalized tunebooks combining written and oral song, as well as German and American influences. As the German population of Pennsylvania increased, it began to expand toward the Shenandoah Valley, crossing through the mountain frontier of Western Maryland and leaving settlers along the southwestward-leading path.

There is evidence that the Brandstetter family was present as far north as Dauphin County, Pennsylvania, and that they lived primarily in Washington County, Maryland beginning at the end of the eighteenth century. This geographic range covers the migration route from Eastern Pennsylvania into Western Maryland. Maria Brandstetter's tunebook—with its mixed languages, chorales alongside fuging tunes, and shaped-notation—-shows the mixture of German and American influences found in adaptive tunebooks. The book's handmade, personalized quality connects it to the Notenbüchlein and singing school traditions of the Franconia Mennonites of Pennsylvania. As such, the Brandstetter tunebook shows us that the German population migrating from Pennsylvania brought their sacred music culture with them, settling new areas with familiar traditions. 
The Brandstetter tunebook in combination with Adam Arnold's Geistliche Ton-Kunst (1803) reveals what sacred music was being performed in early nineteenth-century Western Maryland. Arnold's publication is an early stage of German-immigrant adaptation of Anglo-American music. Though the book is entirely in German and contains a number of chorales, the chorales are arranged in four voices (an Anglo-American trait) and some of the early New England psalm and fuging tunes are set to German texts. The tunes within the Brandstetter tunebook are directly connected to the John Wyeth's Harrisburg, Pennsylvania publication, Wyeth's Repository of Sacred Music (1810), a tunebook that contains early New England psalmody in the shaped-notation of Little and Smith's The Easy Instructor (1801). These tunes employ a three-voice texture in homophonic and fuging styles. The book also presents tunes based on the German chorale tradition, written in two voices, set to chorale texts, but in shaped-notation. The Hagerstown origin of both the Arnold and Brandstetter tunebooks portrays an active and ethnically diverse sacred music culture in early nineteenth-century Western Maryland.

Finally, Maria Brandstetter's tunebook fills in the gap between Eastern Pennsylvania and the Shenandoah Valley, helping to connect two major publishing centers in the history of shape-note dissemination (Harrisburg, Pennsylvania and Harrisonburg, Virginia). Scholarship on shape-note hymnody points to John Wyeth's Repository of Sacred Music (1810) as a major influence on Ananias Davisson's Kentucky Harmony (1816), but as of yet, no one has been able to confirm how the Pennsylvania tunebook made it into Davisson's hands. Maria Brandstetter's tunebook indicates that Wyeth's Repository of Sacred Music was being used in Western 
Maryland as early as 1811 , suggesting that the migrating German population carried the popular shape-note tunebook out of Pennsylvania and into the settlements of Maryland and Virginia, bringing it closer to Davisson's headquarters in Harrisonburg.

Though small and modest in content, Maria Brandstetter's tunebook reveals much about German-American culture and the dissemination of shape-note hymnody in the early nineteenth century. It serves as another illustration of the migrating Germans' adaptive nature, balancing their heritage with the music of the New World. The book also gives us examples of the sacred music heard and performed in the frontier region of Western Maryland, comparable to that of the surrounding areas of rural Pennsylvania and Virginia. As an illustration of shape-note music's dissemination, the tunebook acts as a link between Eastern Pennsylvania and the Valley of Virginia. Its origin in early nineteenth-century Hagerstown, Maryland, and reliance on sources from Harrisburg, Pennsylvania, brings shape-note hymnody across the Mason-Dixon Line and connects the tradition with one of its pivotal compilers in Harrisonburg, Virginia. 


\section{Appendix 1}

\section{An Index to the Brandstetter Tunebook}

\begin{tabular}{|c|c|c|c|}
\hline \multicolumn{4}{|c|}{ American Tunes } \\
\hline Tune & $\begin{array}{c}\text { Page in Brandstetter } \\
\text { Tunebook }\end{array}$ & $\begin{array}{l}\text { Page in Wyeth's } \\
\text { Repository }\end{array}$ & First Line \\
\hline $\begin{array}{l}\text { ADESTE } \\
\text { FIDELES }\end{array}$ & 39 & 56 & O come loud anthems let us sing \\
\hline AMERICA & 24 & 93 & My soul repeats his praise \\
\hline BRIDGEWATER & 20 & 45 & Life is the time to serve the Lord \\
\hline CAMBRIDGE & 46 & 91 & How did my heart rejoice to hear \\
\hline COLESHILL & 30 & 23 & Lord what is man \\
\hline COMMUNION & 41 & 68 & Alas and did my Savior bleed \\
\hline CORONATION & between pages 1 and 2 & 87 & All hail the power of Jesus' name \\
\hline DAUPHIN & 36 & 46 & For life without thy love \\
\hline DEVOTION & 43 & 46 & Sweet is the day of sacred rest \\
\hline DOMINION & 54 & 48 & Jesus shall reign where 'er the sun \\
\hline GRAFTON & 55 & 44 & Jesus the vision of thy face \\
\hline HIDING PLACE & 48 & 22 & $\begin{array}{l}\text { Hail sovereign love that first } \\
\text { began }\end{array}$ \\
\hline LENOX & 4 & 47 & Ye tribes of Adam join \\
\hline MEAR & 59 & 67 & Will God forever cast us off \\
\hline MEDITATION & 58 & 28 & My soul come meditate the day \\
\hline NEWBURGH & 56 & 41 & Let every creature join \\
\hline OCEAN & 49 & 30 & Thy works of glory mighty Lord \\
\hline OLD HUNDRED & 44 & 55 & O come loud anthems let us sing \\
\hline PORTUGAL & 40 & 22 & How lovely how divinely sweet \\
\hline
\end{tabular}




\begin{tabular}{|c|c|c|c|}
\hline REPENTANCE & 53 & 20 & O if my soul was formed for woe \\
\hline ROCHESTER & 28 & 112 & $\begin{array}{c}\text { Come children learn to fear the } \\
\text { Lord }\end{array}$ \\
\hline RUSSIA & 22 & 34 & False are the men of high degree \\
\hline SAMANTHRA & between pages 2 and 3 & - & $\mathrm{O}$ thou in whose presence \\
\hline SHERBURNE & 45 & 21 & $\begin{array}{l}\text { While shepherds watch their } \\
\text { flocks by night }\end{array}$ \\
\hline SOLITUDE NEW & 57 & 49 & My refuge is the God of love \\
\hline SUFFIELD & 26 & 19 & Teach me the measure of my days \\
\hline VIRGINIA & 14 & 18 & $\begin{array}{l}\text { Thy words the raging winds } \\
\text { control }\end{array}$ \\
\hline WELLS & 5 & 58 & $\begin{array}{l}\text { Ye nations round the world } \\
\text { rejoice }\end{array}$ \\
\hline WESLEY & 42 & 68 & $\begin{array}{l}\text { With inward pain my heart-strings } \\
\text { sound }\end{array}$ \\
\hline WHITESTOWN & 39 & 52 & $\begin{array}{l}\text { Where nothing dwelt but beasts of } \\
\text { pray }\end{array}$ \\
\hline
\end{tabular}

German Songs

\begin{tabular}{|c|c|c|}
\hline Text Incipit & Page in Brandstetter Tunebook & Chorale Number in Zahn's Index \\
\hline $\begin{array}{c}\text { Ach Gott erhör Seufzen und } \\
\text { Wehklagen }\end{array}$ & 1 & 1831 \\
\hline Alle Menschen müssen sterben & 3 & 6779 \\
\hline Allein Gott in der höh sey Ehr & 2 & 4457 \\
\hline Christus der ist mein Leben & 6 & 132 \\
\hline Endlich endlich muss es doch & 34 & - \\
\hline Es ist gewisslich an der Zeit & 7 & 4429 \\
\hline $\begin{array}{c}\text { Gott des himmels und der Erden } \\
\text { Herr Jesu, Christ wahr Mensch und }\end{array}$ & 9 & 3614 \\
\hline
\end{tabular}




\begin{tabular}{|c|c|c|}
\hline Herr Jesu gnadensonne & 12 & 4297 \\
\hline Herzlich thut mich verlangen & 13 & 5385 \\
\hline Himmels sonne seelen wonne & 29 & - (no text matches in Zahn) \\
\hline $\begin{array}{l}\text { Jesus meine Zuversicht, und mein } \\
\text { Heiland }\end{array}$ & 8 & 3432 \\
\hline Kommt lasst euch den herren lehren & 16 & - \\
\hline Liebster Jesu, wir sind hier & 25 & 3498 \\
\hline Lobe den herren, den machtigen & 50 & 1912 \\
\hline Mache dich mein Geist beriet & 10 & 6274 \\
\hline Mein heiland habe auf mich acht & 35 & _ (three voice parts) \\
\hline Meine hoffnung stehet veste & 32 & 4870 \\
\hline Mir nach spricht Christus & 19 & 2383 \\
\hline Nun danket alle Gott & 17 & 5070 \\
\hline Nun ruhen alle Wälder & 33 & - \\
\hline O Gott du frommer Gott & 18 & 5148 \\
\hline Ringe recht, wenn Gottes gnade & 37 & - \\
\hline Seele wirt dein sorgen bin & 51 & - (three voice parts) \\
\hline Seelen Bräufigam & 21 & 3255 \\
\hline Unser herrscher, unser König & 31 & 3738 \\
\hline Wachet auf ruft uns die Stimme & 47 & 8405 \\
\hline Was Gott thut das ist wohlgethan & 23 & 5629 \\
\hline $\begin{array}{l}\text { Wie schön leuchtet der } \\
\text { Morgenstern }\end{array}$ & 27 & 8359 \\
\hline Wer nur den lieben Gott & 15 & 2778 \\
\hline $\begin{array}{l}\text { Zeuch mich, zeuch mich mit den } \\
\text { Armen }\end{array}$ & 38 & 3749 \\
\hline
\end{tabular}




\section{Bibliography}

\section{Primary Sources}

Bay Psalm Book, The: A Facsimile Reprint of the First Edition of 1640. Chicago: The University of Chicago Press, 1965.

Davisson, Ananias. Kentucky Harmony, or a Choice Collection of Psalm Tunes, Hymns, and Anthems in Three Parts. Harrisonburg, VA: Ananias Davisson, 1816. Reprint, Irving Lowens, ed. Minneapolis: Augsburg Publishing House, 1976.

. A Supplement to the Kentucky Harmony. Harrisonburg, VA: Ananias Davisson, 1816.

Doll, Joseph. Leichter Unterricht in der vocal Musik. Harrisburg, PA: John Wyeth, 1813.

Funk, Joseph. Die allgemein nützliche Choral-Music. Harrisonburg, VA: Laurentz Wartmann, 1816.

Law, Andrew. The Art of Singing. Cambridge: W. Hilliard, 1803.

Little, William and William Smith. The Easy Instructor; or, A New Method of Teaching Sacred Harmony. New York: G and R Waite, 1802.

Lyon, James. Urania: A Choice Collection of Psalm-Tunes, Anthems, and Hymns. Philadelphia: 1761. Reprint, Richard Crawford, ed. New York: Da Capo Press, 1974.

Melodie und Sing-Buch. Unpublished manuscript tune book compiled for Maria Brandstetter. Washington County, Maryland, 1820. Special Collections in Performing Arts, University of Maryland.

McGraw, Hugh, ed. et al. The Sacred Harp. Bremen, GA: Sacred Harp Publishing Company, 1991.

Tufts, John. An Introduction to the Art of Singing Psalm-Tunes. Boston: Printed for Samuel Gerrish, 1738.

Walker, William. The Southern Harmony and Musical Companion. Philadelphia: E. W. Miller, 1854. Reprint, Glenn C. Wilcox, ed. Lexington, KY: The University Press of Kentucky, 1987. 
White, B. F. and E. J. King. The Sacred Harp. Hamilton, GA: White and Massengale, 1860. Reprint, George Pullen Jackson, ed. Nashville: Broadman Press, 1968. . The Sacred Harp, Philadelphia: T. K. Collins, Jr., 1844.

Wyeth, John. Wyeth's Repository of Sacred Music. Harrisburg, PA: John Wyeth, 1810. Microfilm.

.Wyeth's Repository of Sacred Music. Harrisburg, PA: John Wyeth, 1811. Microfilm.

. Wyeth's Repository of Sacred Music. Harrisburg, PA: John Wyeth, 1812. Microfilm.

. Wyeth's Repository of Sacred Music. Harrisburg, PA: John Wyeth, 1820. Reprint, Irving Lowens, ed. New York: Da Capo Press, 1974.

. Wyeth's Repository of Sacred Music, Part Second. Harrisburg, PA: John Wyeth, 1820. Reprint, Irving Lowens ed. New York: Da Capo Press, 1964.

\section{$\underline{\text { Secondary Sources }}$}

Bealle, John. Public Worship, Private Faith: Sacred Harp and American Folksong. Athens: The University of Georgia Press, 1997.

Beary, Shirley. "Stylistic Traits of Southern Shape-Note Gospel Songs." The Hymn 30 (1979): 26-33.

Billings, William. The Complete Works of William Billings. Karl Kroeger and Hans Nathan eds. Boston: American Musicological Society \& The Colonial Society of Massachusetts, 1981.

Brock, David A. "A Foundation for Defining Southern Shape-Note Folk Hymnody from 1800 to 1859 as a Learned Compositional Style." Ph.D. dissertation, The Claremont Graduate University, 1996.

Broyles, Michael. "Immigrant, Folk, and Regional Musics in the Nineteenth Century." In The Cambridge History of American Music, ed. by David Nicholls, 135-157. New York: Cambridge University Press, 1998.

Bruce, Neely. "Sacred Choral Music in the United States: an Overview." In The Cambridge Companion to Singing, ed. John Potter, 133-148. Cambridge University Press, 2000.

Brugger, Robert J. Maryland: A Middle Temperament 1634-1980. Baltimore: The Johns Hopkins University Press, 1988. 
Burdge Jr., Edsel \& Samuel L. Horst. Building on the Gospel Foundation: The Mennonites of Franklin County, Pennsylvania and Washington County, Maryland, 1730-1970. Scottdale, PA: Herald Press, 2004.

Clarke, Chelsea L. "Jacob Engelbrecht: An Example of German-American Identity in Nineteenth Century Maryland." Master's thesis, University of Maryland, Baltimore County, 2009.

Clawson, Laura. I Belong to this Band, Hallelujah! Community, Spirituality, and Tradition among Sacred Harp Singers. the University of Chicago Press, 2011.

Cobb, Buell. The Sacred Harp: A Tradition and Its Music. Athens: the University of Georgia Press, 1978.

Crawford, Richard. America's Musical Life. New York: W. W. Norton, 2001. . Andrew Law, American Psalmodist. Evanston: Northwestern University Press, 1968.

Cunz, Dieter. The Maryland Germans. Princeton: Princeton University Press, 1948.

Davis, Ronald L. The Formative Years, 1620-1865. Volume 1 of A History of Music In American Life. Malabar, FL: Robert E. Krieger Publishing, 1982.

Ellinwood, Leonard. The History of American Church Music. New York: MorehouseGorham, 1953.

Eskew, Harry Lee. "The Eclectic Harmony: A Middle Tunebook in Middle Tennessee." Notes 58 (2001): 291-301.

. "Shape-Note Hymnody in the Shenandoah Valley, 1816-1860." Ph.D. dissertation, Tulane University, 1966.

Gates, J. Terry. "A Historical Comparison of Public Singing by American Men and Women." Journal of Research in Music Education 37, no. 1 (1989): 32-47.

Gleason, Harold and Warren Becker. Early American Music: Music in America from 1620 to 1920, 2d edition. Bloomington: Frangipani Press, 1981.

Grimminger, Daniel Jay. "Pennsylvania Dutch Tune and Chorale Books in the Early Republic: Music as a Medium of Cultural Assimilation.” Ph.D. dissertation, Claremont Graduate University, 2002.

Gross, Suzanne E. "Hymnody of Eastern Pennsylvania German Mennonite Communities: Notenbüchlein (manuscripts songbooks) from 1780 to 1835." Ph.D. dissertation, University of Maryland, 1994. 
Gross, Suzanne and Wesley Berg. "Singing It 'Our Way': Pennsylvania-German Mennonite Notenbüchlein (1780-1835)." American Music 19 (summer 2001): 190-209.

Hadamer, Armin. "O Come, Come Away: Temperance, shape notes, and patriotism." Lied und populäre Kultur/Song and Popular Culture 45 (2000): 109-120.

Hamm, Charles. "The Chapins and Sacred Music in the South and West." Journal of Research in Music Education 8 (autumn 1960): 91-98.

Harley, Rachel Augusta Brett. “Ananias Davisson: Southern Tune-Book Compiler (1780-1857).” Ph.D. dissertation, University of Michigan, 1972.

Hatchett, Marion J. "Early East Tennessee Shape-Note Tunebooks." The Hymn 46 (July 1995): 28-45.

Heintze, James R. ed. American Musical Life in Context and Practice to 1865. New York: Garland Publishing, 1994.

Jackson, George Pullen. Another Sheaf of White Spirituals. 2d edition. New York and Philadelphia: Folklorica, 1981.

. Down-East Spirituals and Others. Locust Valley, New York: J.J. Augustin, 1953.

. Spiritual Folk-Songs of Early America. 2d edition. New York: Dover, 1964.

. White Spirituals in the Southern Uplands. Chapel Hill: The University of North Carolina Press, 1933.

Kessel, Elizabeth. "Germans on the Maryland Frontier: A Social History of Grederick County, Maryland, 1730-1800.” Ph. D. dissertation, Rice University, 1981.

Loftis, Deborah Carlton. "Southern Harmony Singing: A Tradition of Shape-Note Practice." Performance Practice Review 3 (fall 1990): 165-169.

Lowens, Irving. "John Wyeth's 'Repository of Sacred Music, Part Second': A Northern Precursor of Southern Folk Hymnody." Journal of the American Musicological Society 5 (summer 1952): 114-131. . Music and Musicians in Early America. New York: W. W. Norton, 1964.

Lowens, Irving and Allen P. Britton. “'The Easy Instructor' (1798-1831): A History and Bibliography of the First Shape Note Tune Book." Journal of Research in Music Education 1 (spring 1953), 30-55. 
McKay, David P. and Richard Crawford. William Billings of Boston: EighteenthCentury Composer. Princeton: Princeton University Press, 1975.

Miller, Kiri. “First Sing the Notes': Oral and Written Traditions in Sacred Harp Transmission." American Music 22 (winter 2004): 475-501.

. Traveling Home: Sacred Harp Singing and American Pluralism. Chicago: University of Illinois Press, 2008.

McGrain, John. "The Wagon Roads of Western Maryland." Last modified May 27, 2010. http://www.wmdhistory.org/general/wagon-roads-western-marylandmcgrain1.php.

Music, David W. "Ananias Davisson, Robert Boyd, Reubin Monday, John Martin, and Archibald Rhea in East Tennessee, 1816-26." American Music 1 (autumn 1983): 72-84.

. "Seven 'New' Tunes in Amos Pilsbury's United States' Sacred Harmony (1799) and Their Use in Four-Shape Shape-Note Tunebooks of the Southern United States Before 1860.” American Music 13 (winter 1995): 403-447.

Nead, Daniel W. Maryland's German Heritage. Lancaster, PA: PennsylvaniaGerman Society, 1914. Reprint, Don Heinrich Tolzmann, ed. Bowie, MD: Heritage Books, 1994.

Patterson, Daniel W. "William Hauser's Hesperian Harp and Olive Leaf: Shape-Note Tunebooks as Emblems of Change and Progress." The Journal of American Folkore 101 (1988): 23-36.

Pen, Ron. "Triangles, Squares, Circles, and Diamonds: The 'Fasola Folk' and Their Singing Tradition." In Music of Multicultural America: A Study of Twelve Musical Communities, ed. Lornell and Rasmussen, 209-232. New York: Schirmer Books, 1997.

Polman, Bertus Frederick. "Church Music and Liturgy in the Christian Reformed Church of North America." Ph.D. dissertation, University of Minnesota, 1980.

Rosewall, Richard B. “Singing Schools of Pennsylvania, 1800-1900.” Ph.D. dissertation, University of Minnesota, 1969.

Scharf, J. Thomas. History of Western Maryland. Baltimore: Regional Publishing, 1968.

Scholten, James W. "Amzi Chapin: Frontier Singing Master and Folk Hymn Composer." Journal of Research in Music Education 23 (summer 1975): 109119. 
Seeger, Charles. "Contrapuntal Style in the Three-Voice Shape-Note Hymns." The Musical Quarterly 26 (Oct. 1940): 483-493.

Sebald, Brigita. "The Performance of History: Motivations for Revivalist

Participation in Sacred Harp of the Chesapeake Bay Area." Master's thesis, University of Maryland, 2005.

Stanislaw, Richard J. A Checklist of Four-Shape Shape-Note Tunebooks. Brooklyn: Institute for Studies in American Music, 1978.

Steel, David Warren. "John Wyeth and the Development of Southern Folk Hymnody." Music from the Middle Ages Through the Twentieth Century: Essays in Honor of Gwynn McPeek, ed. Carmelo P. Comberiati and Matthew C. Steel, 357-374. New York: Gordon and Breach Science Publishers, 1988.

. "Lazarus J. Jones and The Southern Minstrel (1849).” American Music 6 (summer 1988): 123-157.

. "Shape-Note Singing in the Shenandoah Valley." (Address delivered to the Singers Glen Music and Heritage Festival, Singers Glen, Virginia, 16 August 1997) http://www.mcsr.olemiss.edu/ mudws/shenandoah.html.

Steel, David Warren with Richard Hulan. The Makers of the Sacred Harp. Urbana: University of Illinois Press, 2010.

Taddie, Daniel. "Solmization, Scale, and Key in Nineteenth-Century Four-Shape Tunebooks: Theory and Practice." American Music 14 (spring 1996): 42-64.

Westermeyer, Paul. "The Evolution of the Music of German American Protestants in Their Hymnody: A Case Study from an America Perspective." In Music in American Religious Experience, ed. Bohlman, Blumhofer, and Chow, 155174. New York: Oxford University Press, 2006.

. "What Shall We Sing in a Foreign Land? Theology and Cultic Song in the German Reformed and Lutheran Churches of Pennsylvania, 1830-1900." Ph.D. dissertation, University of Chicago, 1978.

Williams, Thomas J. C. The History of Washington County, Maryland. Baltimore: Regional Publishing, 1968.

Wolf, Edward C. "Two Divergent Traditions of German-American Hymnody in Maryland circa 1800" American Music 3 (autumn 1985), pp. 299-315.

Zahn, Johannes. Die Melodien der deutschen evangelischen Kirchenlieder. Hildesheim, Germany: Georg Olms Verlagsbuchhandlung, 1963. 